\title{
A new genus of oryzomyine rodents (Cricetidae, Sigmodontinae) with three new species from montane cloud forests, western Andean cordillera of Colombia and Ecuador
}

\author{
Jorge Brito $^{\text {Corresp., } 1}$, Claudia Koch ${ }^{2}$, Alexandre R. Percequillo ${ }^{3}$, Nicolás Tinoco ${ }^{4}$, Marcelo Weksler ${ }^{5}$, C. Miguel Pinto \\ , Ulyses F. J. Pardiñas \\ 1 Instituto Nacional de Biodiversidad (INABIO), Quito, Ecuador \\ 2 Zoologisches Forschungsmuseum Alexander Koenig (ZFMK), Bonn, Germany \\ 3 Departamento de Ciências Biológicas, Escola Superior de Agricultura “Luiz de Queiroz", Universidade de São Paulo, Piracicaba, São Paulo, Brazil \\ 4 Sección de Mastozoología, Museo de Zoología, Facultad de Ciencias Exactas y Naturales, Pontificia Universidad Católica del Ecuador, Quito, Ecuador \\ 5 Setor de Mastozoologia, Departamento de Vertebrados, Museu Nacional, Universidade Federal do Rio de Janeiro, Rio de Janeiro, Brazil \\ 6 Observatorio de Biodiversidad Ambiente y Salud (OBBAS), Quito, Ecuador \\ 7 Instituto de Diversidad y Evolución Austral (IDEAus - CONICET), Puerto Madryn, Argentina \\ Corresponding Author: Jorge Brito \\ Email address: jorgeyakuma@yahoo.es
}

The Andean cloud forests of western Colombia and Ecuador are home to several endemic mammals; members of the Oryzomyini, the largest Sigmodontinae tribe, are extensively represented in the region. However, our knowledge about this diversity is still incomplete, as evidenced by several new taxa that have been described in recent years. Extensive field work in two protected areas enclosing remnants of Chocó montane forest recovered a high diversity of small mammals. Among them, a medium-sized oryzomyine is here described as a new genus having at least three new species, two of them are named and diagnosed. Although externally similar to members of the genera Nephelomys and Tanyuromys, the new genus has a unique molar pattern within the tribe, being characterized by a noticeable degree of hypsodonty, simplification, lamination, and third molar compression. A phylogeny based on a combination of molecular markers, including nuclear and mitochondrial genes, and morphological data recovered the new genus as sister to Mindomys, and sequentially to Nephelomys. The new genus seems to be another example of a sigmodontine rodent unique to the Chocó biogeographic region. Its type species inhabits cloud forest between 1,600-2,300 m in northernmost Ecuador (Carchi Province); a second species is restricted to lower montane forest, 1,200 m, in northern Ecuador (Imbabura Province); a third putative species, here highlighted exclusively by molecular evidence from one immature specimen, is recorded in the montane forest of Reserva Otonga, northern Ecuador (Cotopaxi Province). Finally, the new genus is also recorded in southernmost Colombia (Nariño Department), probably represented there also 
by a new species. These species are spatially separated by deep river canyons through Andean forests, resulting in marked environmental discontinuities. Unfortunately, Colombian and Ecuadorian Pacific cloud forests are under rapid anthropic transformation. Although the populations of the type species are moderately abundant and occur in protected areas, the other two persist in threatened forest fragments. 


\section{A new genus of oryzomyine rodents (Cricetidae,}

2 Sigmodontinae) with three new species from montane

3 cloud forests, western Andean cordillera of Colombia

4 and Ecuador

6 Jorge Brito ${ }^{1}$, Claudia Koch ${ }^{2}$, Alexandre R. Percequillo ${ }^{3}$, Nicolás Tinoco ${ }^{4}$, Marcelo Weksler $^{5}$, C.

7 Miguel Pinto ${ }^{6}$ and Ulyses F. J. Pardiñas ${ }^{1,7}$

$9{ }^{1}$ Instituto Nacional de Biodiversidad (INABIO), Quito, Ecuador

102 Zoologisches Forschungsmuseum Alexander Koenig (ZFMK), Bonn, Germany

$11{ }^{3}$ Departamento de Ciências Biológicas, Escola Superior de Agricultura "Luiz de Queiroz",

12 Universidade de São Paulo, Piracicaba, São Paulo, Brazil

$13{ }^{4}$ Sección de Mastozoología, Museo de Zoología, Facultad de Ciencias Exactas y Naturales,

14 Pontificia Universidad Católica del Ecuador, Quito, Ecuador

$15{ }^{5}$ Setor de Mastozoologia, Departamento de Vertebrados, Museu Nacional, Universidade Federal

16 do Rio de Janeiro, Rio de Janeiro, Brazil

$17{ }^{6}$ Observatorio de Biodiversidad Ambiente y Salud (OBBAS), Quito, Ecuador

$18{ }^{7}$ Instituto de Diversidad y Evolución Austral (IDEAus - CONICET), Puerto Madryn, Chubut, 19 Argentina 
21 Corresponding Author:

22 Jorge Brito

23 Instituto Nacional de Biodiversidad (INABIO), Quito, Pichincha, Zip code 17-07-8976, Ecuador

24 Email address: jorgeyakuma@yahoo.es

\section{ABSTRACT}

27 The Andean cloud forests of western Colombia and Ecuador are home to several endemic mammals; members of the Oryzomyini, the largest Sigmodontinae tribe, are extensively represented in the region. However, our knowledge about this diversity is still incomplete, as evidenced by several new taxa that have been described in recent years. Extensive field work in two protected areas enclosing remnants of Chocó montane forest recovered a high diversity of small mammals. Among them, a medium-sized oryzomyine is here described as a new genus having at least three new species, two of them are named and diagnosed. Although externally similar to members of the genera Nephelomys and Tanyuromys, the new genus has a unique molar pattern within the tribe, being characterized by a noticeable degree of hypsodonty, simplification, lamination, and third molar compression. A phylogeny based on a combination of

37 molecular markers, including nuclear and mitochondrial genes, and morphological data recovered the new genus as sister to Mindomys, and sequentially to Nephelomys. The new genus seems to be another example of a sigmodontine rodent unique to the Chocó biogeographic region. Its type species inhabits cloud forest between 1,600-2,300 m in northernmost Ecuador

41 (Carchi Province); a second species is restricted to lower montane forest, 1,200 m, in northern 
42 Ecuador (Imbabura Province); a third putative species, here highlighted exclusively by molecular

43 evidence from one immature specimen, is recorded in the montane forest of Reserva Otonga,

44 northern Ecuador (Cotopaxi Province). Finally, the new genus is also recorded in southernmost

45 Colombia (Nariño Department), probably represented there also by a new species. These species

46 are spatially separated by deep river canyons through Andean forests, resulting in marked

47 environmental discontinuities. Unfortunately, Colombian and Ecuadorian Pacific cloud forests

48 are under rapid anthropic transformation. Although the populations of the type species are

49 moderately abundant and occur in protected areas, the other two persist in threatened forest

50 fragments.

52 Subjects Biodiversity, Phylogenetics, Taxonomy, Zoology

53 Keywords Andes, Chocó, hypsodonty, Mindomys, Nephelomys, Oryzomyini.

\section{INTRODUCTION}

The Oryzomyini is the largest tribe among the 56 extant sigmodontine rodent clades, and according to current counts, it comprises about 152 living (including 57 historical extinct) species distributed in 33 genera (Weksler, 2015; Pardiñas et al., 2017). It is also the tribe with the widest geographic distribution, extending from the southeastern United States of America to Tierra del Fuego and the Cape Horn islands, plus some oceanic islands and the Antillean region

61 (Weksler, 2006; Pardiñas et al., 2017).

62 An important portion of this noteworthy diversity is associated with the Andean slopes of northern South America (trans-Andean and Andean distribution categories sensu Weksler, 2006: 83). Several authors, using different methodologies and concepts, identified these regions as 
65 major centres of oryzomyine species richness (e.g., Reig, 1984, 1986; Musser et al., 1998;

66 Valencia-Pacheco et al., 2011; Pine, Timm \& Weksler, 2012; Prado \& Percequillo, 2013; Prado

67 et al., 2015; Patton, Pardiñas \& D’Elía, 2015; Maestri \& Patterson, 2016).

68 The Chocó biogeographic region is one of the zones with the greatest biodiversity and

69 endemism on the planet (Myers et al., 2000). For this reason, and because of its high degree of

70 threats to biodiversity, it is considered as one of the 25 Priority Terrestrial Ecoregions of the

71 World and an endemism hotspot (Mittermeier et al., 1999; Myers et al., 2000). This region

72 comprises westernmost Panamá, Colombia and Ecuador and northernmost western Peru. Of the

73 original $260,660 \mathrm{~km}^{2}$ only $24 \%\left(65.000 \mathrm{~km}^{2}\right)$ currently remains as native forest (Brooks et al.,

74 2002). Current threats to biodiversity of this region include climatic change, the advance of

75 human colonization and infrastructure development, and the direct transformation of the land

76 into agricultural fields. In addition, hunting is a problem for several species of birds and

77 mammals (Mittermeier et al., 1999; Brooks et al., 2002).

78 Chocó forests are home to a variety of endemic oryzomyines, ranging from suprageneric

79 clades, such as the Sigmodontomys-Tanyuromys-Melanomys clade (e.g., Pine, Timm \& Weksler,

80 2012), to “Handleyomys", Nephelomys, Mindomys, Transandinomys (e.g., H. alfaroi, N. moerex,

81 N. devius, M. hammondi, T. bolivaris and T. talamancae). Important elements of this trans-

82 Andean oryzomyine radiation are species of Transandinomys and "Handleyomys" (Musser et al.,

83 1998; Almendra et al. 2018), which occupy lowland and montane forests of the Chocó. Despite

84 that, our knowledge of sigmodontine biodiversity of this hotspot is still incomplete. A recent

85 example is the recognition of a new species of Tanyuromys, T. thomasleei Timm, Pine \&

86 Hanson, 2018. In the montane cloud forests of the Chocó also occurs the poorly-known

87 Mindomys hammondi (Thomas, 1913), one of the most enigmatic rodent taxa of South America. 
88 Mindomys is a monotypic genus with uncertain phylogenetic position (Weksler, 2006; Ronez et

$89 a l ., 2020 b$ ), restricted to Ecuadorean forests between Mindo and Alto Tambo (Thomas, 1913;

90 Weksler, Percequillo \& Voss, 2006; Percequillo, 2015; Pinto et al., 2018).

91 One of the major obstacles to our knowledge of Chocó biodiversity is the lack of proper

92 sampling in the region. During the last few years, numerous field expeditions were conducted by

93 the senior author (JB) to assess small mammal assemblages in several sites in northwest

94 Ecuador. As a result, a rich collection of sigmodontine rodents was secured, including at least 20

95 species (Brito \& Arguero, 2016; Curay, Romero \& Brito, 2019). A primary morphological

96 sorting of this material suggested the occurrence of undescribed oryzomyine taxa that, although

97 externally similar to Nephelomys and Tanyuromys, displayed trenchant differences. These results

98 were confirmed by further morphological and molecular analyses, and by the discovery of

99 additional museum material. The goal of this contribution is to provide the description of these

100 new taxa, representing a new genus and two new species of the tribe Oryzomyini, including

101 phylogenetic relationships determined by morphological comparisons and detailed anatomical

102 evidence, partially based on micro-computed tomography (micro-CT). These new cricetids are

103 added to the endemic list of rodents that inhabit the Chocó montane cloud forests of western

104 Andes in Ecuador and Colombia.

105

106 MATERIALS AND METHODS

\section{Studied specimens}

108 Specimens representing the new genus described here were mostly obtained from field

109 expeditions conducted by JB and his team in two Ecuadorian protected areas, Reserva Río

110 Manduriacu and Reserva Drácula. The former reserve was sampled during three consecutive 
111 nights in April 2017 and September 2019; the latter was surveyed during 18 nights between June

1122016 and September 2019. In both places, pitfall traps were employed (Supplemental

113 Information S1), with 10-12 buckets (between 20 and 60 litres of capacity) distributed along an

114 80-120 m drift line, with a total trap effort of 320 trap nights. The pitfall traps were placed near

115 runways, holes, and other signs of small mammal activity, and baited with rolled oats mixed with

116 vanilla and alternating with balanced feed for cows. Handling and all activities regarding

117 specimens followed care and use ethical procedures recommended by the American Society of

118 Mammalogists (Sikes et al., 2016). For the use and care of animals, we follow the guidelines of

119 the Ministry of the Environment of Ecuador, through scientific research authorization $\mathrm{N}^{\circ} 006$ -

120 2015-IC-FLO-FAU-DPAC MAE and N ${ }^{\circ}$ 003-2019-IC-FLO- FAU-DPAC/MAE. Most of the

121 animals were recovered dead, due to the huge amount of rainwater accumulated in the buckets,

122 despite efforts to drain the water daily (during sampling there were heavy downpour rains; the

123 mean annual precipitation in this region surpasses 3,000 mm). Obtained museum study skins,

124 skeletons, fluid-preserved bodies, and tissue samples stored in 96\% ethanol were deposited in the

125 biological collections of the Instituto Nacional de Biodiversidad (INABIO; Quito, Ecuador) and

126 the Departamento de Biología de la Escuela Politécnica Nacional (MEPN; Quito, Ecuador). In

127 addition, one further specimen belonging to the new genus was originally collected by CMP and

128 deposited in the Museo de Zoología de la Pontificia Universidad Católica del Ecuador (QCAZ).

129 Finally, two Colombian specimens are housed at the Instituto de Ciencias Naturales (ICN;

130 Universidad Nacional de Colombia, Bogotá). As comparative materials we employed specimens

131 of Mindomys hammondi, including those of the type series housed at The Natural History

132 Museum (BMNH; London, United Kingdom), specimens housed at the Royal Ontario Museum

133 (ROM; Toronto, Canada), the Zoologisches Forschungsmuseum Alexander Koenig (ZFMK; 
134 Bonn, Germany), and at the Museum of Zoology, University of Michigan (UMMZ; Ann Arbor,

135 USA). We also inspected series of the genera Nephelomys and Tanyuromys from Ecuador. All

136 examined specimens are listed in the Supplemental Information S2.

137

138 Anatomy, age criteria and measurements

139 To describe cranial anatomy, we followed the criteria and nomenclature established by

140 Hershkovitz (1962), Voss (1988), Carleton \& Musser (1989), Steppan (1995), Martinez et al.

141 (2018) and Wible \& Shelley (2020). Molar occlusal morphology was assessed based on Reig

142 (1977), and stomach gross morphology was interpreted according to Carleton (1973). We

143 followed the terminology and definitions employed by Tribe (1996) and Costa et al. (2011) for

144 age classes and restricted the term "adults" for those in categories 3 and 4 . We obtained the

145 following external measurements in millimetres $(\mathrm{mm})$, some of them registered in the field and

146 reported from specimen tags, others recorded in museum cabinets: head and body length (HB),

147 tail length (TL), hind foot length (HF, including claw), ear length (E), length of longest mystacial

148 vibrissae (LMV), length of longest superciliary vibrissae (LSV), length of longest genal vibrissae

149 (LGV), and body mass (W, in grams). Cranial measurements were obtained with digital

150 callipers, to the nearest $0.01 \mathrm{~mm}$. We employed the following dimensions (see Voss, 1988;

151 Brandt \& Pessôa, 1994; and Musser et al., 1998 for illustrations): occipitonasal length (ONL),

152 condylo-incisive length (CIL), length of upper diastema (LD), crown length of maxillary

153 toothrow (LUM), length of incisive foramen (LIF), breadth of incisive foramen (BIF), breadth of

154 M1 (BM1), breadth of rostrum (BR), length of nasals (LN), length of palatal bridge (LPB),

155 breadth of bony palate (BBP), least interorbital breadth (LIB), zygomatic breadth (ZB), breadth

156 of zygomatic plate (BZP), lambdoidal breadth (LB), orbital fossa length (OFL), bular breadth 
157 (BB), length of mandible (LM), crown length of mandibular toothrow (LLM), and length of

158 lower diastema (LLD). Finally, dental measurements, the maximum length and width of each

159 individual molar, were obtained under magnification using a reticulate eyepiece.

160

161 Scanning

162 To improve the anatomical scrutiny, and also to appreciate the morphology of internal bony

163 structures, the skulls of the holotypes of the two new species (MECN 5928, MEPN 12605)

164 described herein were scanned with a high-resolution micro-computed tomography (micro-CT)

165 desktop device (Bruker SkyScan 1173, Kontich, Belgium) at the ZFMK. To avoid movements

166 during scanning, the skulls were placed in a small plastic container embedded in cotton wool.

167 Acquisition parameters comprised: An X-ray beam (source voltage $43 \mathrm{kV}$ and current $114 \mu \mathrm{A}$ )

168 without the use of a filter; 1,200 projections of $500 \mathrm{~ms}$ exposure time each with a frame

169 averaging of 5 recorded over a $360^{\circ}$ continuous rotation, resulting in a scan duration of $1 \mathrm{~h} 13$

$170 \mathrm{~min}$; a magnification setup generating data with an isotropic voxel size of $15.97 \mu \mathrm{m}$ (MEPN

171 12605) and $17.04 \mu \mathrm{m}$ (MECN 5928), respectively. The CT-dataset was reconstructed with N-

172 Recon software (Bruker MicroCT, Kontich, Belgium) and rendered in three dimensions using

173 CTVox for Windows 64 bits version 2.6 (Bruker MicroCT, Kontich, Belgium). For comparison,

174 the holotype of Mindomys hammondi (BMNH 13.10.24.58) was characterized at the Imaging

175 Analysis Centre of the BMNH using a Nikon Metrology HMX ST 225 (Nikon, Tring, UK).

176 Acquisition parameters comprised: An X-ray beam (source voltage $100 \mathrm{kV}$ and current $150 \mu \mathrm{A}$ )

177 filtered with $0.1 \mathrm{~mm}$ of copper; 3,142 projections of $500 \mathrm{~ms}$ exposure time each with a frame

178 averaging of 2 recorded over a $360^{\circ}$ continuous rotation; a magnification setup generating data

179 with an isotropic voxel size of $22.67 \mu \mathrm{m}$. A filtered back projection algorithm was used for the 
180 tomographic reconstruction, using the CT-agent software (Nikon Metrology GmbH, Alzenau,

181 Germany), producing a 16-bit uncompressed raw volume. Finally, this dataset was rendered in

182 three dimensions with Amira software (Thermo Fisher Scientific, Hillsboro, USA).

183

184 Statistics

185 Females and males were combined in all analyses following Voss (1991) and Abreu-Jr. et al.

186 (2012), who concluded that sexual dimorphism was not an important source of morphometric

187 variation in oryzomyine rodents. Main univariate descriptive statistics were calculated for the

188 two species described here. We also compared adults using a principal component analysis

189 (PCA) based on log (natural)-transformed cranial measurements and the covariance matrix.

190 PCAs were performed on two subsets of basic data in order to allow the inclusion of different

191 specimens. In an approach focused on Ecuadorian specimens from Drácula and Río Manduriacu

192 samples, we worked on a matrix including six external (HB, TL, HF, E, LMV, LGV), 19 cranial

193 (ONL, CIL, LD, LUM, LIF, BIF, BM1, BR, LN, LPB, BBP, LIB, ZB, BZP, OFL, BB, LM,

194 LLM, LLD), and 12 dental (LM1, WM1, LM2, WM2, LM3, WM3, Lm1, Wm1, Lm2, Wm2,

195 Lm3, Wm3) dimensions. To maximize the geographic coverage including Colombian specimens,

196 we worked on a subset composed of three external (HB, TL, HF), and 12 cranial (CIL, LD,

197 LUM, BIF, BM1, BR, LN, LPB, LIB, ZB, BZP, OFL) dimensions. Statistical procedures were

198 carried out using the software Statistica and PAST (PAleontologicalSTatistics), version3.21

199 (Hammer, 1999-2018).

200

201 DNA amplification and sequencing 
202 DNA extraction was made from liver or muscle samples preserved in $90 \%$ ethanol, and from

203 samples taken from museum specimens preserved in $70 \%$ ethanol, or as dry skin specimens. In

204 the case of the fluid specimens, samples of muscle or part of the tragus of the ear were taken.

205 Samples of a hind paw or part of the tragus of the ear were taken from dry skin specimens. These

206 samples were subjected to a washing of salts and buffers to eliminate residues that may affect

207 extraction or PCR. For fresh tissue samples (90\% ethanol), DNeasy (Qiagen) or Puregene

208 (Gentra) extraction kits were used. For museum samples the protocol of Bilton \& Jaarola (1996)

209 was used. We amplified two genes: the mitochondrial cytochrome-b (Cytb) gene using the

210 protocol and primers of Arellano, Gonzáles-Cózalt \& Rogers (2006), and the nuclear

211 interphotoreceptor retinoid binding protein (IRBP) gene using the protocol and primers described

212 in Jansa \& Voss (2000). The amplicons were sequenced by the company Macrogen (South

213 Korea, Inc). The sequences were edited and assembled using the software Geneious R11

214 (https://www.geneious.com) and aligned using the Clustal-W tool.

215

216 Morphologic analysis

217 Oryzomyines were scored for the characters described by Weksler (2006) and Percequillo,

218 Weksler \& Costa (2011), and employed in previous analyses of oryzomyines (e.g., Voss \&

219 Weksler, 2009; Pine, Timm \& Weksler, 2012; Turvey et al., 2010; Turvey, Brace \& Weksler,

220 2012; Ronez et al., 2020b). The taxonomic sampling of the morphological matrix corresponds to

221 that of Pine et al. (2012) with the addition of the new material described here (Supplemental

222 Information S3). We employed the "polymorphic" coding of Wiens (1995) for characters with

223 intraspecific variation, and some characters were treated as ordered, following Weksler (2006).

224 The morphological character matrix constructed for the analyses is provided as Supplemental 
225 Information S3, with some modifications on characters referring to number of mammae

226 (characters 1-3), interorbital region (24-26), and braincase (28).

\section{Phylogenetic analyses}

229 We conducted phylogenetic analyses using three datasets: a total evidence matrix combining morphological characters with the molecular data (Cytb and IRBP), with only one terminal per taxon; a molecular-only analysis (Cytb, IRBP and Cytb + IRBP) using the taxon sampling of Weksler (2006) plus new taxa (13 new sequences from Cytb, and 7 new sequences from IRPB, obtained in this study). The phylogenetic trees of the first 2 datasets were rooted using the neotomine Peromyscus maniculatus and the tylomyine Nyctomys sumichrasti. using maximum parsimony (MP; Farris, 1983; Swofford et al., 1996), maximum likelihood (ML; Felsenstein 1981), and Bayesian inference (BI; Huelsenbeck et al., 2001; Yang \& Rannala, 1997), while the molecular datasets were analysed with ML and BI. See Supplemental Information S4 for GenBank accession number, voucher specimens of analysed material and sources of sequences. The heuristic search algorithm implemented by PAUP* version 4.0a166

241 (Swofford, 2002) was used in parsimony analyses. Each heuristic search employed 1,000 replicates of random taxon addition with TBR branch swapping; clades with at least 1 unambiguous synapomorphy were the only ones retained. Jackknife support values (Farris et al.,

244 1996) for the parsimony analyses were calculated using 1,000 pseudoreplicates, with heuristic 245 searches employed within each replicate $(36.8 \%$ character removal per replicate; 10 random 246 addition replicates, TBR branch swapping, no more than 100 trees saved per replicate). 
248 PartitionFinder (Lanfear et al., 2012). The models for Cytb were: first position GTR + I + G,

249 second position HKY + G, and third position GTR + I + G; for IRBP were: first position HKY +

$250 \mathrm{G}$, second position and $\mathrm{K} 80+\mathrm{G}$ and third position $\mathrm{K} 80+\mathrm{G}$, and $\mathrm{GTR}+\mathrm{G}+\mathrm{I}$ for all partitions

251 of Cytb and K80 + G for all partitions of IRBP. The parsimony model of Lewis (2001) was used

252 for the morphological characters. The maximum-likelihood trees were calculated using RAxML

253 (Stamatakis, 2006). Bayesian analyses were performed using Markov Chain Monte Carlo

254 sampling as implemented in Mr Bayes 3.1 (Huelsenbeck \& Ronquist, 2001; Ronquist \&

255 Huelsenbeck, 2003). Uniform interval priors were assumed for all parameters except base

256 composition, for which we assumed a Dirichlet prior. We performed 4 independent runs of

$25710,000,000$ generations each, with two heated chains sampling for trees and parameters every

258 10,000 generations. The first 2,500,000 generations were discarded as burn-in, and the remaining

259 trees were used to estimate posterior probabilities for each node. All analyses were checked for

260 convergence by the effective sample size (ESS $\geq 500)$, and the potential scale reduction factor

261 was also verified (PSRF $=1$ ). Nodal bootstrap values for the likelihood analysis were calculated

262 using 1,000 pseudoreplicates, under the GTRCAT model in RAxML (Felsenstein, 1985;

263 Stamatakis, 2006). Phylogenetic analyses were run in the CIPRES Science Gateway (Miller,

264 Pfeiffer \& Schwartz, 2010).

265

\section{Genetic distances and saturation analysis}

267 The uncorrected genetic p-distances were calculated using the Mega 7 program (Kumar, Stecher

268 \& Tamura, 2016), the comparisons were made at different taxonomic levels: among the genus

269 most related to the new genus that we describe (Euryoryzomy, Hylaeamys, Handleyomys, 
270 Nephelomys, Oecomys and Transandinomys) and among the three new species. Including 26

271 described species and 3 new taxa. The matrix includes sequences from $796 \mathrm{bp}$ to $1,140 \mathrm{bp}$

272 (Supplemental Intormation S3). To explore the degree of saturation, we performed a saturation

273 analysis in the DAMBE6 (Xia, 2017) program where we plotted the divergence of the sequences

274 against the number of substitution (transitions and transversions), for each gene partition and for

275 each codon position.

276 New Zoological Taxonomic Names

277 The electronic version of this article in Portable Document Format (PDF) will represent a

278 published work according to the International Commission on Zoological Nomenclature (ICZN),

279 and hence the new names contained in the electronic version are effectively published under that

280 Code from the electronic edition alone. This published work and the nomenclatural acts it

281 contains have been registered in ZooBank, the online registration system for the ICZN. The

282 ZooBank LSIDs (Life Science Identifiers) can be resolved and the associated information viewed

283 through any standard web browser by appending the LSID to the prefix http://zoobank.org/. The

284 LSID for this publication is: urn:lsid:zoobank.org:pub:3E11AF88-BD56-40BE-9D43-

285 EF6E5998E2D1. The online version of this work is archived and available from the following

286 digital repositories: PeerJ, PubMed Central and CLOCKSS.

288 Results

\section{Phylogeny}

290 The combined matrix of morphological and molecular datasets included 1,126 variables and 818

291 parsimony-informative characters, of which 95 were morphological characters, 491 from Cytb, 
292 and 232 from IRBP. Phylogenetic trees produced by maximum likelihood and Bayesian analyses

293 of this supermatrix were similar (Fig. 1), with high proportions of nodes with high support, i.e.

294 bootstrap support $(\mathrm{BS})>85 \%$ and posterior probability $(\mathrm{PP})>0.95$. These trees are also similar

295 to previous phylogenetic results for Oryzomyini (Percequillo, Weksler \& Costa, 2011; Pine,

296 Timm \& Weksler, 2012; Turvey et al., 2010; Voss \& Weksler, 2009; Weksler, 2003; Weksler,

297 2006), with the tribe reconfirmed as monophyletic, and four major clades consistently recovered

298 (clades A to D of Weksler, 2006). Clades B, C, and D have high nodal support (BS $>90 \%$ and

$299 \mathrm{PP}=1$ ), and clade A (containing Scolomys and Zygodontomys) has a lower support (BS $=88 \%$

300 and $\mathrm{PP}=0.77$ ). The topological base of Oryzomyini remains unchanged from previous analyses,

301 with clade C (Oreoryzomys, Neacomys, Microryzomys, and Oligoryzomys) representing the sister

302 group to clade D (Holochilus, Pseudoryzomys, Oryzomys, Nectomys, Amphinectomys,

303 Aegialomys, Nesoryzomys, Melanomys, Sigmodontomys, Tanyuromys, Eremoryzomys,

304 Drymoreomys, Cerradomys, Sooretamys, and Lundomys) with high nodal support (BS =98\%,

305 PP = 1). Clade B (Transandinomys, Euryoryzomys, Nephelomys, Oecomys, Hylaeamys,

306 Handleyomys, Mindomys), including the new taxa, represented by specimens from Reserva

307 Drácula (sp. 1), and Reserva Río Manduriacu (sp. 2), as well as a specimen from Reserva La

308 Otonga (sp. 3), is sister to clade $\mathrm{C}+\mathrm{D}$ with high nodal support $(\mathrm{BS}=99 \%, \mathrm{PP}=1)$. Most

309 intergeneric relationships within clades C and D have high nodal support, but intergeneric

310 relationships within clade B are still poorly supported. Nevertheless, a clade containing

311 Nephelomys, Mindomys and the new taxa was recovered with high support $(\mathrm{BS}=100 \%, \mathrm{PP}=$

312 0.99); within this clade, Mindomys was constantly recovered as the sister species to the clade

313 formed by the three new taxa described here, albeit with medium support $(\mathrm{BS}=72 \%, \mathrm{PP}=0.96)$.

314 The only notable differences between Maximum likelihood and Bayesian inferences include the 
315 non-recovery of Handleyomys as a monophyletic group in the former, and of Melanomys in the

316 latter; these two differences, however, involve relationships with low nodal support.

317 Parsimony analysis of the supermatrix resulted in four most parsimonious trees $(6,967$

318 steps, $\mathrm{CI}=0.21, \mathrm{RI}=0.59)$, the strict consensus of which showed a few changes compared to the

319 structure of trees as recovered in the ML and BI analyses; clades C and D were not recovered as

320 monophyletic, with Oligoryzomys not clustering with Oreoryzomys, Microryzomys, and

321 Neacomys, and Eremoryzomys and Drymoreomys not recovered within clade D. As also

322 described in Pine, Timm \& Weksler (2012), this structure is probably due to the phylogenetic

323 signal saturation of the mitochondrial Cytb in higher-level relationships within Oryzomyini in

324 the parsimony analysis (Weksler, 2003), which does not correct for multiple substitutions.

325 Results for saturation analysis in DAMBE corroborate this, as cytochrome b was found to be 326 saturated in all its codon positions (Supplemental Information S6). In any case, clade B was

327 recovered as monophyletic, and within it a clade containing Mindomys, Nephelomys and the new 328 taxa was also recovered with high support $(\mathrm{BS}=87 \%)$; in addition, Mindomys and the new taxa

329 were found as sister taxa $(\mathrm{BS}=86 \%)$.

330 Phylogenetic analyses of the expanded molecular-only matrix (Cytb+IRBP) (Fig. 2), also

331 recovered the new taxa as a monophyletic group in clade B (sensu Weksler, 2006); nevertheless,

332 the new taxa were nested within a paraphyletic Nephelomys. The clade of the new taxa was sister

333 to Nephelomys levipes, and in turn this clade sister to Mindomys hammondi. Nodal support for

334 the clade with the new taxa is high, as well as for the clade including the paraphyletic

335 Nephelomys, Mindomys and the new taxa; the support for the internal clades are low to moderate,

336 including the clades containing Mindomys and N. levipes + new taxa. 
The phylogenetic analyses of each gene separately presented different topologies, in the

338

339

340

341

342

343

344

345

346

347

348

349

350

351

352

353

354

355

356

357

358

359 case of the Cytb gene (Supplemental Information S5A) Mindomys was located nested in

Nephelomys, while this genus was paraphyletic. The samples of the new species described here

formed a monophyletic clade sister to Nephelomys + Mindomys, and the samples from Reserva

Otonga (sp 3) and Reserva Dracula (sp 1) formed a clade with high supports, and this in turn, it was recovered as a brother to the samples from the Reserva Rio Manduriacu ( $\mathrm{sp} 3$ ). The IRBP gene (Supplemental Information S5B) brought Mindomys back as the sister taxon to a clade

formed by Nephelomys and the new species described here. Within this clade Nephelomys was paraphyletic since $N$. keaysi and $N$. levipes formed a clade with the samples of the new species described (Supplemental Information S5B). In the case of the new species, the samples from the Reserva Dracula (sp 1) and the Reserva Rio Manduriacu (sp 2) formed a clade with high supports, it was recovered as a brother to the samples from the Reserva Otonga (sp 3 ).

The saturation results showed that the mitochondrial gene Cytb presents a degree of saturation both in the first and second position of the codon, while, in the third position, a high degree of saturation (Supplemental Information 6A-C). In the case of the IRBP nuclear gene, I do not present any degree of saturation in the three positions of the codon. The saturation found in the Cytb gene may explain the low resolution in the relationship at the species level (Supplemental Information S6A) as is the case Nephelomys, Mindomys and the new genus described here. While the IRBP gene presented a better resolution among the species of the genera mentioned above (Supplemental Information S6B).

The levels of genetic differentiation (Table 1) of this new genus with respect to the genera integrating clade B (Weksler, 2006) ranged from 11.91\% (Nephelomys) to $15.64 \%$ (Hylaeamys). Intrageneric distances among samples from Reserva Drácula (sp. 1), Reserva Río Manduriacu

Peer) reviewing PDF | (2020:06:50405:2:0:NEW 28 Sep 2020) 
360 (sp. 2), and Reserva Otonga (sp. 3), were approximately 7\% (sp. 1 vs sp. $2=7.87 \% \pm 0.87$; sp. 1

361 vs sp. $3=7.55 \% \pm 0.83 ;$ sp. 2 vs sp. $3=7.28 \% \pm 0.96)$.

362

363 Morphological comparisons

364 In this section, we compare the new genus with both the phylogenetically closer lineages

365 Mindomys and Nephelomys, and the geographically closer genus Tanyuromys (see Table 2).

366 Specimens of Mindomys exhibit a large body size (HB range: 173-293 mm), while body

367 sizes of adult specimens of the new genus, its sister taxon, are smaller $(115-140 \mathrm{~mm})$, as are HB

368 ranges Tanyuromys (150-142 mm), and Nephelomys (100-228 mm). The tail is very long in

369 individuals of all taxa of this clade, surpassing the HB length: Mindomys (TL > $222 \mathrm{~mm}$ ),

370 Nephelomys (TL range: 102-253 mm), and the new genus (TL range: 180-184 mm). Specimens

371 of Nephelomys have much more sharply bicolored tails than individuals of the new genus, which

372 lack distinct countershading and have monochrome-dark tails. The dorsal surface of the hindfoot

373 is naked looking in the new genus, scarcely covered by short hairs in Nephelomys and

374 Tanyuromys while it is densely covered by short hairs in Mindomys. Pes are relatively long

375 (range: $35-36 \mathrm{~mm}$ ) and narrow in the new genus, similar to Nephelomys (range: $30-42 \mathrm{~mm}$ ) and

376 Tanyuromys (range: 30-37 mm), but distinct from Mindomys, which exhibit very long (range:

$377 \quad 38-42 \mathrm{~mm}$ ) but much wider pes, configuring a shorter appearance (Weksler, 2006; Percequillo, 378 2015).

379 Nephelomys skulls are characterized by moderately deep and wide zygomatic notches,

380 while these are noticeably shallower and narrower in Mindomys and in the new genus (Fig. 3).

381 The new genus also exhibits a narrower and longer rostrum when compared to Mindomys and

382 Nephelomys. The interorbital region is anteriorly convergent, with sharp supraorbital margins in 
383 the new genus, and hourglass-shaped, slightly convergent anteriorly or posteriorly with rounded

384 or squared margins in Nephelomys, and slightly anteriorly convergent, with squared, beaded or

385 slightly crested margins in Mindomys. In the new genus, the posterolateral palatal pits are single

386 and small, while in Mindomys the pits are numerous and recessed in a shallow palatine

387 depression. In Nephelomys the pits are also numerous, but variably positioned at the palate level,

388 or from shallow to deeply excavated palatine depressions (that also vary form narrow and

389 oblique to wide and round). The alisphenoid strut is present in all specimens of the new genus

390 (Fig. 4), configuring separated buccinator-masticatory and ovale accessory foramen, but is

391 variably present in species of Nephelomys (present in most individuals of $N$. moerex, and absent

392 in most specimens of $N$. devius), and absent in specimens of Mindomys and Tanyuromys. The

393 subsquamosal fenestra is small in the new genus, well-developed in Nephelomys, and absent in

394 Mindomys and Tanyuromys. The squamosal ridge is absent in the new genus, present in

395 Nephelomys and Tanyuromys, and barely present in Mindomys (Fig. 3).

396 The molar rows are medium sized with respect to the skull size in the new genus, being

397 shorter in Nephelomys, and longer in Mindomys and Tanyuromys. The molar design is

398 moderately laminated in the new genus (Fig. 5), but definitively not laminated in Nephelomys,

399 Mindomys, and Tanyuromys. The enamel borders of lophs and lophids in all molars are smooth

400 in the new genus and in Nephelomys and Mindomys, while in Tanyuromys the borders are

401 crenulate. The procingulum of M1 is compressed, without anteromedian flexus in the new genus

402 (Fig. 5), broad with deep anteromedian flexus in Nephelomys, broad without flexus in Mindomys,

403 and broad with flexus and anterior fossete in Tanyuromys. The anterolophs of M1-M2 are small

404 or absent in the new genus and present in Nephelomys, Mindomys, and Tanyuromys. There is a

405 perceptible variation in the size of M3 relative to the size of M2: in the new genus $\mathrm{M} 3<\mathrm{M} 2$, 
406 while in Nephelomys, Mindomys and Tanyuromys M3<M2. The mesolophs of M1-M2 are absent

407 or poorly developed in the new genus (Fig. 5), but present and well developed in M1-M2 of

408 Nephelomys, Mindomys, and Tanyuromys. The procingulum of $\mathrm{m} 1$ is compressed and lacks the

409 anteromedian flexid in the new genus, but is broad with flexid in Nephelomys, and broad with an

410 anterior fossetid in Mindomys and Tanyuromys. The anterior murid of $\mathrm{ml}$ is absent in the new

411 genus, but present in Nephelomys, Mindomys and Tanyuromys. The $\mathrm{m} 3$ is subtriangular and

412 compressed in the new genus, while not compressed in Nephelomys, Mindomys and Tanyuromys.

413 The accessory root of M1 is present in the new genus and in Tanyuromys (Supplemental

414 Information S7), but absent in Nephelomys and Mindomys. The accessory root of m1, and two

415 accessory roots of $\mathrm{m} 2-\mathrm{m} 3$ are present in Tanyuromys, while absent in the new genus, and in

416 Nephelomys and Mindomys (Supplemental Information S7).

417

418 Geographic variation: Studied samples of the new genus came from different montane forest

419 blocks distributed in the Pacific slope of the Andean Cordillera Occidental (Ecuador and

420 Colombia). As this humid and cold forest band is transversally interrupted by several important

421 east-to-west river canyons (from north to south, Güiza, Mira, Guayllabamba, and Toachi; Fig. 6),

422 we focused on the detection of potential morphological differences among examined

423 populations, under the assumption that habitat discontinuities promote allopatric speciation. This

424 inspection was directed to the animals collected in Reserva Drácula and Reserva Río

425 Manduriacu, the two largest available collections. The collection from Reserva Otonga is

426 composed of a single young specimen with the third molars not fully erupted and was thus

427 discarded from the analysis. The northernmost samples of the new genus, two individuals from

428 Colombia, were also discarded, because we were unable to review the voucher material. 
Specimens from Drácula $(n=12)$ and Río Manduriacu reserves $(n=4)$ are externally very

430 similar, although the fur of the latter is less dorsoventrally countershaded because of the grayer

431 bellies. These chromatic differences are also displayed in the tails, which are darker above and

432 below in animals from Río Manduriacu. In contrast, several cranial and dental traits exhibit fixed

433 differences between both samples. Drácula specimens are characterized by a broad dorsal

434 expression of the antorbital bridge, an alar fissure typically without a basal notch, and a small but 435 constant participation of the parietals in the lateral wall of the cranium. In contrast, the antorbital 436 bridge from specimens of Río Manduriacu is dorsally narrow, the alar fissure has a marked basal 437 notch, and the lateral expansions of the parietals are absent. Conspicuous differences between 438 both samples are even better expressed in the dentition. The enamel of the upper incisors are 439 cream or white-colored in animals from Drácula, while those of specimens from Río Manduriacu 440 are bright orange-colored. In addition, probably due to a slight difference in hypsodonty, occlusal

441 design in Drácula specimens is moderately complex showing incipient anterolophs and well

442 developed mesolophs in both M1 and M2. Conversely, Río Manduriacu specimens typically lack 443 both structures.

444 Since molars accounted for several important morphological differences between both 445 populations, we calculated Mahalanobis distances on molar individual measurements and 446 performed a cluster analysis. The obtained result grouped the examined animals separately 447 according to geographic provenance, reinforcing the taxonomic hypothesis that we are dealing 448 with two differentiable entities of specific rank (Supplemental Information S8). To further 449 explore metrical differences, we used principal component analysis to summarize patterns of 450 multivariate craniodental variation. The first two principal components accounted for about $54 \%$ 451 of the total variance (Supplemental Information S9). Projected specimen scores indicated a poor 
452 sample separation of the first two components, the coefficients of which suggested that Río

453 Manduriacu specimens differ from Drácula specimens by their slightly longer ears and

454 comparatively shorter molars. To strengthen the morphometric analysis, we ran a PCA based

455 exclusively on measurements showing significant univariate differences $(p<0.05)$ between both

456 samples; these were CIL, BBP, length of M2, and length of $\mathrm{m} 1$. As expected, the variance

457 explained by the first two principal components increased to about $75 \%$ and the distribution of

458 the specimens in the multivariate space showed that the animals from Río Manduriacu are

459 smaller than those of Drácula (Supplemental Information S9). When individuals from southern

460 Colombia were included in a PCA performed with a matrix composed of those variables with

461 significant differences ( $p<0.05$; CIL, LD, BIF, BR, LN, ZB, and BZP), similar results were

462 obtained (Supplemental Information S9). In this instance, Colombian animals were grouped

463 separately, highlighting their larger size, a fact that can be assessed from a direct inspection of

464 Table 3. Although two individuals obtained the craniodental measurements (JB measured

465 Ecuadorian animals while ARP measured Colombian ones), differences were well beyond

466 expected differences due to methodological bias. Finally, a PCA (Fig. 7) was conducted on a

467 matrix exclusively composed of all measured craniodental variables (i.e., excluding external

468 measurements in order to avoid the potential negative effect of mixing larger and smaller

469 dimensions). Although the variance explained by the first two principal components reached

470 almost $85 \%$, one of the two specimens from Rio Manduriacu was placed among those of Drácula

471 Reserve (Supplemental Information S9).

472 At the phylogenetic level, specimens from Rio Manduriacu and the Drácula Reserve were

473 allocated to different monophyletic clades (Supplemental Information S5-S6), and in turn these 
474 were recovered as sister clades (Figs. 1-2). These clades show a considerable genetic divergence 475 ( $7.90 \%$ higher), allowing these populations to be considered different taxonomic entities.

476 Summarizing, we interpret these overall results to indicate the presence of two species of 477 the new genus under discussion, one in the forest of Reserva Drácula and the other in the forest 478 of Reserva Río Manduriacu. Fortunately, morphological qualitative and quantitative evidence is 479 in accordance with the clear separation of these samples on molecular grounds. Regarding the 480 Colombian specimens, they seem to be metrically larger than the Ecuadorian specimens, but 481 further studies are needed to establish their taxonomy.

482 The data presented indicate that the new rice rats discussed here are representatives of a 483 new genus of Oryzomyini. In addition, we advance evidence of at least two, and possibly three, 484 species within this new genus. We provide below a definition of the genus, followed by a 485 description and a discussion of its relationships, and morphological descriptions of two of the 486 recognized species.

\section{Systematic accounts}

489 Family Cricetidae Fischer, 1817

490 Subfamily Sigmodontinae Wagner, 1843

491 Tribe Oryzomyini Vorontsov, 1959

492 Pattonimus gen. nov.

493 urn:lsid:zoobank.org:act: 83926983-C0A8-4337-B5F9-81B01CF7B487

494 Patton's montane rat, Rata montana de Patton

495 Sigmodontomys: Cadena, Anderson \& Rivas-Pava (1998: 11), part, not Sigmodontomys Allen, $496 \quad 1897$ 
497 Mindomys: Pinto et al. (2018: figs. 2, 5, and Appendix); part, not Mindomys Weksler,

498 Percequillo \& Voss, 2006.

499

500 Type species: Pattonimus ecominga sp. nov.

501

502 Diagnosis: A medium-sized (adult combined head and body length $\sim 130 \mathrm{~mm}$; body mass $\sim 60$

503 grams; condyle-incisive length $\sim 30 \mathrm{~mm}$; coronal maxillary toothrow length $\sim 5.6 \mathrm{~mm}$ ) member

504 of the tribe Oryzomyini characterized by the following combination of characters: body pelage

505 short and close, reddish brown dorsally (dorsal hairs with agouti banding pattern) with a subtle

506 darker middorsal stripe, ventral hairs plumbeous washed with yellowish tones, weak

507 countershading; mystacial vibrissae abundant and longer than ears when laid backwards; ears

508 rounded, haired and small; tail longer than combined length of head-and-body (130\%) and naked

509 in appearance, unicolored; 8 mammae; cranium with moderately long $(\sim 35 \%$ of the

510 occipitonasal length) and wide rostrum, shallow zygomatic notches, interorbital region with

511 sharp frontals anteriorly convergent, zygomatic plate broad and excavated; carotid arterial

512 pattern primitive, alisphenoid strut present, short and broad hamular process of squamosal,

513 incisive foramen short, teardrop-shaped, well anterior to the M1s anterior faces, palate narrow

514 and short, posterior palatal foramen inconspicuous, broad mesopterygoid fossa, broader than

515 parapterygoid plates; maxillary toothrows slightly divergent backwards; molars large, with

516 tendency towards lamination, moderate hypsodonty and simplification; procingulum of M1

517 anteriorly-posteriorly compressed, mesolophs/ids absent to moderately developed, hypocone

518 connected to paracone, procingulum of $\mathrm{m} 1$ undivided, typically with a central fossetid, anterior

519 murid typically absent (protoflexid confluent with metaflexid), anterolabial cingula strongly 
520 developed in all upper and lower molars, $\mathrm{m} 3$ anteriorly-posteriorly compressed; first rib with

521 dual articulation (seventh cervical and first thoracic vertebrae), 12 ribs; second thoracic vertebra

522 with elongated neural spine; 19 thoracicolumbar vertebrae; 4 sacrals, $34-36$ caudals, the first

523 four with hemal arches; stomach unilocular-hemiglandular, with glandular epithelium extended

524 to the corpus; gall bladder absent.

525

526 Morphological description: Adult body fur fine and short (dorsal hairs averages $7-8 \mathrm{~mm}$ ),

527 moderately soft, but not woolly; black guard hairs extend slightly beyond the body fur, not much

528 longer than the regular coat except on the rump; upperparts and underparts are sharply

529 delineated; dorsal fur reddish brown with a subtle darker middorsal stripe; individual overhairs

530 exhibit an agouti banding pattern (basal three-fourths plumbeous, followed by an ochraceous-

531 reddish band, then a blackish tip), usually darker on rump; flanks tending to more reddish;

532 ventral pelage paler agouti, sometimes grayish; head with marked brown-darker fur reaching the

533 rhinarium; whitish gular patch; eyes small. Mystacial, superciliary, genal, submental, interramal,

534 and carpal vibrissae present; mystacial vibrissae abundant (about 20 per side) and long, some

535 extending posteriorly beyond caudal margins of pinnae when laid back against cheeks; ears large

536 and clearly visible above fur of head, moderately clothed with soft reddish hairs on the basal

537 third externally, the rest nearly naked (sparsely covered with very short reddish hairs) on both

538 surfaces; helix and antitragus poorly developed (Fig. 8E). Upper lips densely covered with

539 whitish hispid hairs; rhinarium with well-developed nasal pads; philtrum present (Fig. 8F). The

540 tops of the fore and hindfeet are almost naked, poorly covered with scarce and fine whitish hairs;

541 digits naked; except plantar digit 1 (hallux), the end of each one bears a few silvery hairs which

542 slightly surpass the tip of the claw; manus ventral surface naked, finely scutellate and sometimes 
543 dark pigmented, with five fleshy plantar tubercles (Fig. 8B); claws short, unusually recurved,

544 basally opened, except the pollex which bears a nail; pes long and narrow, with outer digits (1

545 and 5) much shorter than middle three (claw of $\mathrm{d} 1$ extending to middle of first phalange of $\mathrm{d} 2$,

546 claw of d5 extending just beyond first interphalangeal joint of d4); plantar surface naked, dark

547 pigmented, with finely squamae (scale-like tubercles) and complete pad dotation (2 metatarsal

548 and 4 interdigital tubercles; Fig. 8D). Tail longer than combined length of head-and-body

549 (130\%), apparently naked but with 3 fine and rigid very short hairs per scale (Fig. 8I), and

550 unicolored (dark above and below), slightly paler below. Mammae 8 in inguinal, abdominal,

551 postaxial, and pectoral pairs.

552 Skull with moderately long (about $35 \%$ of ONL) and wide rostrum, the greater width

553 results from the relatively inflated nasolacrimal capsules and the broad premaxillaries; rostral

554 sides taper gradually forward from nasolacrimal capsules, but premaxillary bones can be seen to

555 extend for almost their entire length along the nasal margins except its distal portion hidden

556 beneath nasals; nasals gradually diverging forward with distal end moderately upturned; shallow

557 but distinct zygomatic notches (Fig. 3); notable internal bony development in the respiratory and

558 olfactory sagittal plane: two frontoturbinals, one interturbinal and three ethmoturbinals present

559 (Supplemental Information 10); interorbit wide, anteriorly convergent with sharp but not beaded

560 supraorbital margins, extending posteriorly, concealing external sutures of parietals and

561 interparietal, and imparting a "tennis racket" appearance to braincase in dorsal view; fronto-

562 parietal suture ranging from V-shaped to U-shaped; braincase moderately inflated and elongated,

563 with marked temporal crests; cranial roof dorsal profile flat from nasals to the half of parietals to

564 slope sharply downward toward the occiput; foramen magnum is oriented posteroventrad and the

565 occipital condyles are inconspicuous viewed from above; interparietal well developed, covering 
566 almost the entire rear portion of the braincase, flanked by exoccipitals. Premaxillae slightly

567 shorter than nasals, not produced anteriorly beyond incisors to form a rostral tube; gnathic

568 process small but distinct; zygomatic plate broad and excavated, its anterior edge slightly sloping

569 forward, with an angular anterodorsal contour and a thick antorbital bridge; antorbital foramen

570 basally narrowed; zygomatic arches sturdy and robust with jugals spanning a short segment of

571 each mid-arch but distinctly separating zygomatic processes of the maxillary and squamosal

572 bones; maxillary extension of the zygomatic arch with a typically patent projection in its lower

573 border; zygomatic arches with ventralmost projection above the floor of the orbit; squamosal-

574 alisphenoid groove poorly visible through the translucent braincase, usually without a perforation

575 where it crosses the depression for the masticatory nerve, leading to a small sphenofrontal

576 foramen sometimes hidden by the alar fissure; large stapedial foramen and carotid canal but

577 barely expressed petrotympanic fissure; primitive cephalic arterial supply (pattern 1 of Voss,

578 1988); alisphenoid strut consistently present, separating buccinator-masticatory foramen and

579 foramen ovale (Fig. 4); postglenoid foramen narrow separated from an also narrow,

580 subsquamosal fenestra by short and broad hamular process of squamosal; well-developed tegmen

581 tympani mostly covering subsquamosal fenestra and contacting squamosal border but neither

582 overlapping nor involving a distinct posterior suspensory squamosal process; squamosal root of

583 zygomatic arch produced backwards as a short ridge well above the hamular process; small

584 lateral expressions of parietals barely present; bullae small; pars flaccida of tympanic membrane

585 present, large; orbicular apophysis of malleus well developed. Hill foramen moderately large;

586 incisive foramina short, teardrop-shaped, averaging about $50 \%$ of diastemal length, well anterior

587 to the M1s anterior faces; capsular process of premaxillary well developed and covering $2 / 3$ of

588 incisive foramina; palate narrow and short, almost uncomplicated (shallow lateral grooves), with 
589 the anterior border of the mesopterygoid fossa even with the plane defined by M3s posterior

590 faces; posterior palatal foramen inconspicuous; small posterolateral pits usually paired and

591 located side by side with the anterior part of the mesopterygoid fossa, never recessed in a

592 common fossa; broad mesopterygoid fossa, broader than parapterygoid plates, with anterior

593 margin U-shaped; bony roof of fossa complete; squared and short hamular processes of

594 pterygoid sometimes contacting spinous processes of the bony Eustachian tubes; periotic well 595 exposed.

596 Mandible moderately elongated, robust, with well-developed falciform coronoid process

597 with its tip slightly surpassing the condyle level; mental foramen laterally placed; incisor case

598 broad; inferior masseteric ridge well-marked, while superior masseteric ridge short and both

599 conform an oblique and short common masseteric crest; condyle broad with well-developed pre-

600 and postcondylid processes; lower incisor alveolus without distinct capsular process on lateral

601 mandibular surface; lunar notch poorly excavated; angular process short and broad.

602 Upper incisors ungrooved, opisthodont, narrow but deep, with yellow-orange (P. musseri

603 sp. nov.) to cream (P. ecominga sp. nov.) enamel bands and straight dentine fissure. Maxillary

604 molar rows slightly divergent backwards; upper molars large, with tendency towards lamination

605 (labial and lingual reentrant folds long and interpenetrating) and moderate hypsodonty (Fig. 5);

606 coronal surfaces slightly crested in young and subadults, tending planar in adults and old

607 individuals; M1 >M2>>M3 in length; main cusps slightly alternated and sloping backwards when

608 viewed from side; M1 subrectangular in outline with procingulum not divided into labial and

609 lingual conules, anteriorly-posteriorly compressed, without anteromedian flexus; anterior face

610 rimmed by conspicuous enamel shelf; protocone isolated, connected to paracone through a

611 minute enamel bridge; anteroloph barely present; mesoloph typically absent (P. musseri sp. nov.) 
612 to present (P. ecominga sp. nov.), and if present fused to minute mesostyles in adult individuals

613 (in both species); posteroloph usually present as a small fossete; M2 squared in outline but

614 posteriorly compressed with a procingulum limited to a labial loph; mesoloph, mesostyle, and

615 posteroloph showing the same condition as in M1; M3 subtriangular in outline with an

616 inconspicuous hypoflexus and a compressed posterior lobe. M1 four-rooted (with one accessory

617 labial root but without external expression); M2 and M3 three-rooted.

618 Mandibular molars with main cusps alternated and sloping backwards when viewed from

619 side. First mandibular molar (m1) with procingulum undivided, anteriorly-posteriorly moderately

620 compressed, typically showing a large central fossetid of uncertain homology (probably formed

621 from the fusion of two fossetids) and a well-developed labial cingulum fused to a protolophid

622 which rarely closes the protoflexid; anterior murid barely present (protoflexid confluent with

623 metaflexid). Procingulum of $\mathrm{m} 1$ not divided into labial and lingual conulids; metaflexid fused

624 with the protoflexid; metaconid connected to protoconid through a narrow bridge; anterolophid

625 indistinct; mesolophid absent in $\mathrm{m} 1$ and $\mathrm{m} 2 ; \mathrm{m} 2$ squared in outline; $\mathrm{m} 3$ triangular in outline with

626 a deep hypoflexid and a compressed posterior lobe. All mandibular molars two-rooted.

627 Tuberculum of first rib articulates with transverse processes of seventh cervical and first

628 thoracic vertebrae; second thoracic vertebra with differentially elongated neural spine;

629 thoracicolumbar vertebrae 19 , the 17 th with moderately developed anapophyses; sacrals 4 ;

630 caudals 34-36, with complete hemal arches in the first four; ribs 12; entepicondylar foramen of

631 humerus absent; supratrochlear foramen of humerus present.

632 Gross stomach configuration (in three dissected specimens of $P$. ecominga sp. nov.)

633 unilocular-hemiglandular (sensu Carleton, 1973), with a shallow but marked incisura angularis

634 and with the limit (bordering fold) between internal epithelia crossing the organ clearly to left of 
635 the esophageal opening; therefore, the glandular lining is extended to corpus and has a folded

636 internal surface (Figs. 8G, 8H). Gall bladder absent (according to three dissected specimens of $P$.

637 ecominga sp. nov. and of one P. musseri sp. nov.).

638 Phallic, male reproductive characters, and karyotype undetermined.

639

640 Contents: Two species are described here as Pattonimus ecominga sp. nov., and Pattonimus

641 musseri sp. nov.; one or possibly two additional species are presumably known.

642

643 Geographic distribution: Known from the western Andean cordillera of Colombia, Department 644 of Nariño, and Ecuador, provinces of Carchi and Cotopaxi (Fig. 6), at elevations from ca. 1,200 645 to $2,350 \mathrm{~m}$.

646

647 Etymology: The generic name (a noun in the nominative singular) is derived from the surname 648 Patton and the Latin noun mus (= mouse, rat). This name honours the figure and legacy of James

649 L. Patton, Emeritus Curator of Mammals and Professor of Integrative Biology, at the Museum of 650 Vertebrate Zoology, University of California, in Berkeley, USA. James Patton inspired 651 generations of mammalogists, through his adventurous field-trips and not so memorable 652 shipwrecks, outstanding scientific contributions and supervision and mentoring of numerous 653 students around the world (see Patton, 2005; Rodríguez-Robles \& Greene, 2005). 654

655 Pattonimus ecominga sp. nov.

656 urn:Isid:zoobank.org:act:15A88558-F671-46C8-8826-D0E3962F620C

657 Ecominga montane rat, Rata montana de Ecominga 
658

659 Holotype: MECN 5928 (field number JBM 2218), an adult male specimen preserved as a skull, 660 partial postcranial skeleton and skin in regular condition; collected by Jenny Curay, Rocío 661 Vargas, Camila Bravo, and Jorge Brito on 14 April 2019. 662

663 Paratopotypes: MECN 5927 (JBM 2223), an adult female, and MECN 6034 (JBM 2229), an 664 adult male, both preserved as skull, partial postcranial skeleton and skin in regular condition; 665 collected by J. Curay, R. Vargas, C. Bravo, and J. Brito between 15 and 17 April 2019. 666

667 Other paratypes: MECN 6017 (JBM 1936), a young female preserved as skull, partial 668 postcranial (boneless autopodium) and skin in regular condition; collected in Pailón Alto $669\left(0.97415^{\circ} \mathrm{N}, 78.2176^{\circ} \mathrm{W}, 1,630 \mathrm{~m}\right)$ by J. Brito, J. Curay, and R. Vargas on 7 November 2017. 670 MECN 5293 (JBM 1456), an adult male; MECN 5297 (JBM 1460), an adult male; MECN 5298 671 (JBM 1461), a young male; MECN 5304 (JBM 1467), a young male; MECN 5308 (JBM 1471), 672 an adult female; MECN 5309 (JBM 1472), a young male; MECN 5310 (JBM 1473), an adult 673 female; MECN 5325 (JBM 1488), an adult male; MECN 5326 (JBM 1489), an adult male; and 674 MECN 5382 (JBM 1665), a young male. All these specimens were preserved as a crushed skull 675 cranium and mandible partially covered by dry tissues, with carcass and viscera in ethanol. All of 676 them were collected in Gualpi, Km. 18 of the Gualpi road $\left(0.853841^{\circ} \mathrm{N}, 78.237600^{\circ} \mathrm{W}, 2,350\right.$ 677 m) by J. Brito, J. Robayo, L. Recalde, T. Recalde and C. Reyes on 27 September 2016. MECN 6786019 (JBM 2048), an adult male; MECN 6020 (JBM 2063), an adult male; MECN 6025 (JBM 679 2064), an adult male; MECN 6040 (JBM 2051), an adult female; MECN 6041 (JBM 2052), an 680 adult female; MECN 6042 (JBM 2056), an adult male; and MECN 6043 (JBM 2057), an adult 
681 female. All these specimens were preserved as skull, partial postcranial skeleton (boneless 682 autopodium) and skin in regular condition. All of them were collected in Gualpi, Km. 18 of the 683 Gualpi $\operatorname{road}\left(0.853841^{\circ} \mathrm{N}, 78.237600^{\circ} \mathrm{W}, 2,350 \mathrm{~m}\right)$ by H. Yela, J. Robayo, and J. Brito on 12 684 May 2018. MECN 4991 (JBM 1310), a young female; preserved as skull, with carcass and 685 viscera in ethanol; collected at Km. 14 of the Gualpi road $\left(0.882408^{\circ} \mathrm{N}, 78.223235^{\circ} \mathrm{W}, 1,970\right.$ $686 \mathrm{~m})$ by J. Brito, J. Robayo, L. Recalde, T. Recalde, and C. Reyes on 5 June 2016. 687

Type locality: Gualpilal $\left(0.891944^{\circ} \mathrm{N}, 78.20308^{\circ} \mathrm{W}\right.$, [coordinates taken by GPS at the trap site], 689 elevation 1,700 m), Km. 12 of the Gualpi road, Reserva Drácula, Parroquia Chical, Canton 690 Tulcán, Provincia Carchi, República del Ecuador.

691

692 Diagnosis: A species of Pattonimus gen. nov. with antorbital bridge dorsally broadened, alar 693 fissure typically without a basal notch, a small contribution of parietals in the lateral view, upper 694 incisors with enamel cream or white-colored, and molar occlusal topography moderately 695 complex including mesolophs in M1-M2.

696

697 Morphological description of the holotype and variation: Dorsal fur reddish brown with a 698 subtle darker middorsal stripe; flanks tending to more reddish (Fig. 9); ventral pelage grayish 699 (Supplemental Information S11); tail long and unicolored (dark above and below), some 700 specimens are slightly paler below. Cranium with moderately long and wide rostrum (Fig. 10);

701 rostral sides taper gradually forward from nasolacrimal capsules; nasals gradually divergent

702 forward with distal ends moderately upturned; shallow but distinct zygomatic notches; interorbit 703 wide, anteriorly convergent with sharp supraorbital margins; fronto-parietal suture V-shaped; 
704 braincase moderately inflated and elongated; cranial roof dorsal profile flat from nasals to the

705 half of parietals to slope sharply downward toward the occiput; foramen magnum oriented

706 posteroventrad; premaxillae slightly shorter than nasals, not produced anteriorly beyond incisors

707 to form a rostral tube; gnathic process small but distinct; zygomatic plate broad and excavated,

708 its anterior edge slightly sloping backwards; zygomatic arches sturdy and robust; maxillary

709 extension of the zygomatic arch with a projection in its lower border; squamosal-alisphenoid

710 groove poorly visible through the translucent braincase, without a perforation where it crosses

711 the depression for the masticatory nerve; small stapedial foramen and carotid canal and barely

712 expressed petrotympanic fissure; primitive cephalic arterial supply (pattern 1 of Voss, 1988);

713 alisphenoid strut consistently present, separating buccinator-masticatory foramen and foramen

714 ovale; large anterior opening of alisphenoid canal; postglenoid foramen narrow separated from

715 an also narrow subsquamosal fenestra by short and broad hamular process of squamosal (Fig.

716 11); incisive foramina short, teardrop-shaped, well anterior to the M1s anterior faces; capsular

717 process of premaxillary well developed; palate narrow and short; with the anterior border of the

718 mesopterygoid fossa defined by M3s posterior faces; small posterolateral pits paired and located

719 side by side to the anterior part of the mesopterygoid fossa; squared and short hamular processes;

720 mandible robust; inferior masseteric ridge well-marked; upper incisors with cream enamel bands

721 and straight dentine fissures. Maxillary molar rows slightly divergent backwards; upper molars

722 large, with tendency to lamination and moderate hypsodonty; coronal surfaces slightly crested;

723 main cusps slightly alternated and sloping backwards when viewed from side; M1 subrectangular

724 in outline with procingulum not divided into labial and lingual conules, anteriorly-posteriorly

725 compressed, without anteromedian flexus; mesoloph present; posteroloph present as a small

726 fossete; M2 squared in outline but posteriorly compressed with a procingulum limited to a labial 
727 loph; mesoloph, mesostyle, and posteroloph showing the same condition as in M1; M3

728 subtriangular in outline with an inconspicuous hypoflexus and a compressed posterior lobe (Fig.

729 12); mandibular molars with main cusps alternated and sloping backwards when viewed from

730 side; procingulum of $\mathrm{m} 1$ not divided into labial and lingual conulids; metaflexid fused with the

731 protoflexid; metaconid connected to protoconid through a narrow bridge; anterolophid indistinct;

732 mesolophid absent; posterolophid present and large; $\mathrm{m} 2$ squared in outline; mesolophid and

733 posterolophid showing the same condition as in $\mathrm{m} 1$; $\mathrm{m} 3$ triangular in outline with a deep

734 hypoflexid and a compressed posterior lobe; enlarged cingulum anterolabial (Fig. 12); gross

735 stomach configuration unilocular-hemiglandular (Fig. 8); gall bladder absent; three diastemal

736 and seven interdentals palatal rugae; the interdental palatal rugae $2-7$ with jagged anterior edges.

737

738 Measurements (in mm, except body mass) of the holotype: Head and body length $=145$, tail

739 length $=180$, hind foot length $=37$, ear length $=17$, length of longest mystacial vibrissae $=52$,

740 length of longest superciliary vibrissae $=32$, length of longest genal vibrissae $=20$, body mass $=$

$74118 \mathrm{~g}$, occipitonasal length $=34.31$, condylo-incisive length $=31.87$, length of upper diastema $=$

7428.9 , crown length of maxillary toothrow $=5.63$, length of incisive foramen $=4.98$, breadth of

743 incisive foramina $=1.84$, breadth of $\mathrm{M} 1=1.73$, breadth of rostrum $=6.3$, length of nasals $=$

74412.31 , length of palatal bridge $=7.31$, breadth of bony palate $=2.76$, least interorbital breadth $=$

7455.68 , zygomatic breadth $=17.2$, breadth of zygomatic plate $=3.87$, lambdoidal breadth $=12.87$,

746 orbital fossa length $=11.12$, bular breadth $=3.98$, length of mandible $=18.62$, crown length of

747 mandibular toothrow $=5.59$, length of lower diastema $=4.06$, length $\mathrm{M} 1=2.72$, width $\mathrm{M} 1=$

7481.77 , length $\mathrm{M} 2=1.75$, width $\mathrm{M} 2=1.78$, length $\mathrm{M} 3=1.24$, width $\mathrm{M} 3=1.35$, length $\mathrm{m} 1=2.28$, 
749 width $\mathrm{m} 1=1.66$, length $\mathrm{m} 2=1.72$, width $\mathrm{m} 2=1.68$, length $\mathrm{m} 3=1.47$, width $\mathrm{m} 3=1.34$.

750 Measurements for the paratypes are given in Tables 3-4.

751

752 Distribution: Known from several neighboring collecting sites in Reserva Drácula (Carchi,

753 Ecuador), on the western flank of the Andes (Fig. 6), at an elevation of 1,600-2,340 m.

754

755 Natural history: Reserva Drácula is located in the headwaters of the río Gualpi in the

756 subtropical and lower montane ecosystem (Cerón et al., 1999). The local expression of the cloud

757 montane forest is characterized by a tree canopy that reaches $30 \mathrm{~m}$ high; the understory is

758 luxurious and mostly composed of species belonging to Araceae, Melastomataceae,

759 Cyclanthaceae, Bromeliaceae, and ferns (Supplementary Information S12). A recently captured

760 specimen showed a calm behavior, foraging on the ground between the roots (Supplementary

761 Information S13), where we observed it feeding on small seeds. From the same pit falls where $P$.

762 ecominga sp. nov. was obtained, we also collected the sigmodontines Chilomys sp., Melanomys

763 caliginosus, Microryzomys minutus, Nephelomys cf. pectoralis, Oecomys sp., Rhipidomys

764 latimanus, Tanyuromys thomasleei, and Thomasomys bombycinus, the heteromyid Heteromys

765 australis, the marsupials Caenolestes convelatus, Mamosops caucae, and Marmosa sp., and the

766 soricid Cryptotis equatoris.

767

768 Etymology: The specific name is the Spanish name "ecominga;" it honours the NGO Fundación

769 EcoMinga, an Ecuadorian foundation with international sponsors, focused on the conservation of

770 the unique foothill forests, cloud forests, and alpine grasslands ("páramo") of the Andes, 
771 especially those on the edge of the Amazon basin in east-central Ecuador and those on the super-

772 wet western Andean slopes of the Chocó region in northwest Ecuador.

773

774 Conservation: Most parts of the Reserva Drácula are primary forests that have never been cut

775 (at least, according to the historical records). However, significant portions of this forest have

776 recently been cleared along the road to establish fields of "naranjilla" plantations (Solanum

777 quitoense), a fruit of high commercial value. This plant produces good crops for two years. After

778 that, the soil becomes contaminated with pathogens and pesticides, so the cultivation is no longer

779 profitable, and these old fields are abandoned or used as pasture.

780

781 Pattonimus musseri sp. nov.

782 urn:lsid:zoobank.org:act:A50ABD02-60BA-497C-9DCE-83D6C7811305

783 Musser's montane rat, Rata montana de Musser

784

785 Holotype: MEPN 12605 (field number JBM 1752), an adult female represented by a skull and

786 partial postcranial skeleton and skin in good condition; collected by J. Brito and Glenda Pozo on

$787 \quad 12$ April 2017.

788

789 Paratopotypes: MEPN 12586 (JBM 1733), an adult female; MEPN 12593 (JBM 1740), a young

790 male; and MEPN 12587 (JBM 1734), an adult male; all preserved as skulls, partial postcranial

791 skeletons and museum skins in regular conditions and collected by J. Brito and G. Pozo between

79212 and 14 April 2017.

793 
794 Type locality: Reserva Río Manduriacu $\left(0.309547^{\circ} \mathrm{N}, 78.856631^{\circ} \mathrm{W}\right.$, [coordinates taken by

795 GPS at the trap site], elevation 1,200 m), Parroquia García Moreno, Cantón Cotacachi, Provincia

796 Imbabura, República del Ecuador.

797

798 Diagnosis: A species of Pattonimus gen. nov. with antorbital bridge dorsally narrow, alar fissure

799 with a basal notch, lateral expression of parietal absent, upper incisors with enamel orange-

800 colored, and molar occlusal topography simplified, typically lacking mesolophs on M1-M2.

801

802 Morphological description of the holotype and variation: Dorsal fur reddish brown with a

803 darker middorsal stripe; flanks tending to more reddish; ventral pelage grayish (Supplemental

804 Information 14); tail long and unicolored (dark above and below). Cranium with moderately long

805 and wide rostrum; rostral sides taper gradually forward from nasolacrimal capsules (Fig. 13);

806 nasals gradually divergent forward with distal ends moderately upturned; shallow but distinct

807 zygomatic notches; with antorbital bridge dorsally narrowed (Fig. 11); interorbit wide, anteriorly

808 convergent with sharp supraorbital margins; fronto-parietal suture U-shaped; braincase

809 moderately inflated and elongated; cranial roof dorsal profile flat from nasals to the half of

810 parietals to slope sharply downward toward the occiput; foramen magnum oriented

811 posteroventrad; premaxillae slightly shorter than nasals, not produced anteriorly beyond incisors

812 to form a rostral tube; gnathic process small but distinct; zygomatic plate broad and excavated,

813 its anterior edge slightly sloping backwards; zygomatic arches sturdy and robust; maxillary

814 extension of the zygomatic arch with projection in its forward border; squamosal-alisphenoid

815 groove poorly visible through the translucent braincase, without a perforation where it crosses

816 the depression for the masticatory nerve; small stapedial foramen and carotid canal but barely 
817 expressed petrotympanic fissure; primitive cephalic arterial supply (pattern 1 of Voss, 1988);

818 alisphenoid strut consistently present, separating buccinator-masticatory foramen and foramen

819 ovale; small anterior opening of alisphenoid canal; alar fissure with a basal notch, lateral

820 expression of parietal absent (Fig. 11); postglenoid foramen narrow, subsquamosal fenestra

821 small, narrow and long hamular process of squamosal; square tegmen tympani. Incisive foramen

822 short, teardrop-shaped, well anterior to the M1s anterior faces; capsular process of premaxillary

823 well developed; palate narrow and short; with the anterior border of the mesopterygoid fossa

824 defined by M3s posterior faces; small posterolateral pits paired and located side by side to the

825 anterior part of the mesopterygoid fossa; squared and short hamular processes; petrosal little

826 exposed (Fig. 13); mandible robust, with the vertical branch straight (Fig. 13); inferior masseteric

827 ridge well-marked; upper incisors with enamel orange-colored and straight dentine fissure;

828 maxillary molar rows slightly divergent backwards; upper molars large, with tendency to

829 lamination and moderate hypsodonty; coronal surfaces slightly crested; main cusps slightly

830 alternated and sloping backwards when viewed from side; M1 subrectangular in outline with

831 procingulum not divided into labial and lingual conules, anteriorly-posteriorly compressed,

832 without anteromedian flexus; mesoloph absent (Fig. 12); posteroloph present as a small fossete;

833 M2 squared in outline but posteriorly compressed with a procingulum limited to a labial loph;

834 mesoloph, mesostyle, and posteroloph showing the same condition as in M1; M3 subtriangular in

835 outline with an inconspicuous hypoflexus and a compressed posterior lobe; mandibular molars

836 with main cusps alternate and sloping backwards when viewed from side. Procingulum of $\mathrm{m} 1$

837 not divided into labial and lingual conulids; metaflexid fused with the protoflexid; metaconid

838 connected to protoconid through a narrow bridge; anterolophid indistinct; mesolophid absent

839 (Fig. 12); posterolophid present and large; $\mathrm{m} 2$ squared in outline; mesolophid and posterolophid 
840 showing the same condition as in $\mathrm{m} 1 ; \mathrm{m} 3$ triangular in outline with a deep hypoflexid and a

841 compressed posterior lobe.

842

843 Measurements (in mm, except body mass) of the holotype: Head and body length $=140$, tail

844 length $=177$, hind foot length $=35$, ear length $=19$, length of longest mystacial vibrissae $=$

84549.17 , length of longest superciliary vibrissae $=28.42$, length of longest genal vibrissae $=19.14$,

846 body mass $=59 \mathrm{~g}$, occipitonasal length $=31.2$, condylo-incisive length $=29.05$, length of upper

847 diastema $=7.96$, crown length of maxillary toothrow $=5.56$, length of incisive foramen $=4.72$,

848 breadth of incisive foramina $=1.73$, breadth of $\mathrm{M} 1=1.7$, breadth of rostrum $=6.03$, length of

849 nasals $=12.03$, length of palatal bridge $=6.77$, breadth of bony palate $=2.43$, least interorbital

850 breadth $=5.68$, zygomatic breadth $=16.51$, breadth of zygomatic plate $=3.49$, lambdoidal

851 breadth $=13.1$, orbital fossa length $=10.06$, bular breadth $=3.75$, length of mandible $=16.93$,

852 crown length of mandibular toothrow $=5.31$, length of lower diastema $=4.17$, length $\mathrm{M} 1=2.65$,

853 width $\mathrm{M} 1=1.70$, length $\mathrm{M} 2=1.48$, width $\mathrm{M} 2=1.75$, length $\mathrm{M} 3=1.25$, width $\mathrm{M} 3=1.41$,

854 length $\mathrm{m} 1=1.94$, width $\mathrm{m} 1=1.50$, length $\mathrm{m} 2=1.76$, width $\mathrm{m} 2=1.67$, length $\mathrm{m} 3=1.43$, width

$855 \mathrm{~m} 3=1.38$. Measurements for the paratypes are given in Tables 3-4.

856

857 Etymology: This species is named in honour of Guy G. Musser (1936-2019), outstanding

858 collector and taxonomist devoted to the study of worldwide muroid rodents (Carleton, 2009).

859 We adopted as ours what Voss (2009: 3) wrote about Musser's legacy, "his publications set new

860 standards in systematic mammalogy." The species epithet is formed from the surname "Musser,"

861 taken as a noun in the genitive case, with the Latin suffix "i”" (ICZN 31.1.2).

862 
863 Distribution: Restricted to the type locality on the western flank of the Andes, Reserve Río

864 Manduriacu, Imbabura province, Ecuador (Fig. 6), at an elevation of 1,200 m.

865

866 Natural history: Reserva Río Manduriacu is placed in the headwaters of the Manduriacu River,

867 a region belonging to the subtropical ecosystem (Albuja et al., 2012). The vegetation corresponds

868 to the Low Montane Evergreen Forest of the western slopes of the Andes (Cerón et al., 1999).

869 From the same pit falls where P. musseri sp. nov. was obtained, we also collected the

870 sigmodontines Neacomys tenuipes, Melanomys caliginosus, Tanyuromys thomasleei,

871 Transandinomys bolivaris, the heteromyid Heteromys australis, and the marsupial Mamosops

872 caucae.

873

874 Conservation: The reserves Río Manduriacu and Drácula are threatened by the expansion of

875 mining concessions across the northwest of Ecuador (Roy et al., 2018; Guayasamin et al., 2019).

876 The western Andean slopes from Ecuador (Chocó Region) have shown important micro-regions

877 of small vertebrate endemism, which are restricted to areas with good-quality forest and very

878 little or no anthropogenic activity (e.g. Yánez-Muñoz et al., 2018; Guayasamin et al., 2019).

879 Thus, activities that threaten these Chocó forests must be regulated and authorized within the

880 framework of the Ecuadorian Constitution. A program of conservation actions for biodiversity is

881 also needed for the Ecuadorian Andes. Such program have advanced mostly with the

882 participation of non-profit institutions that aim to protect priority and vulnerable forests for

883 biodiversity conservation, such as those carried out by the Fundación EcoMinga (Yánez-Muñoz

884 et al., 2018; Guayasamin et al., 2019). 
886 Pattonimus sp.

887 Referred material: QCAZ 8720, preserved as skull (Supplemental Information S15) and body 888 in fluid, collected at Otonga $\left(0.4189^{\circ} \mathrm{N}, 79.0039^{\circ} \mathrm{W}, 2,065 \mathrm{~m}\right)$, Provincia Cotopaxi, Ecuador 889 (Pinto et al., 2018); ICN 13663 and ICN 21487, preserved as skulls and skins, collected at the 890 Fundación Ecológica Los Colibries de Altaquer (1.293111 $\left.{ }^{\circ} \mathrm{N}, 78.073972^{\circ} \mathrm{W}, 1,100 \mathrm{~m}\right)$, Reserva 891 del río Ñambi, Corregimiento Altaquer, Municipio de Barbacoas, Departamento Nariño, 892 Colombia (Cadena, Anderson \& Rivas-Pava, 1998).

893

894 Remarks: More field work is necessary in Reserva Otonga (Ecuador) and in the Reserva del Río 895 Nambi (Colombia), in order to collect additional material that allows exploring both morphology 896 and genetics to properly allocate these populations.

897

\section{DISCUSSION}

Pattonimus gen. nov. molar morphology in oryzomyine dental morphospace: The recognition of Pattonimus gen. nov. as a distinct genus, i.e., a separate evolutionary lineage occupying a unique biogeographic and ecological zone, is supported by several pieces of

902 information, including molecular data and integumental and cranial characters. Nevertheless, it is

903 the unique molar morphology of Pattonimus gen. nov. among oryzomyines that provides the best

904 evidence for the ecological significance of this taxon. To our perception, this genus represents a

905 novel transition to a dental morphospace within the tribe that combines lamination, increased

906 crown height (i.e., relatively more hypsodont), occlusal simplification, and a mesiodistally

907 compressed m3 (Fig. 14). 
Molar morphology, including tooth proportions, crown height, and occlusal topography,

909 shows important variation within Oryzomyini (Musser et al., 1998; Weksler, 2006). This is not

910 unexpected, since this tribe has a noticeable taxonomic diversity (40 genera including both

911 extinct and extant genera), and displays significant variation in body sizes, diets, life modes, and

912 biomes colonized (e.g., Voss, 1991; Carleton \& Musser, 1989; Musser et al., 1998; Weksler

913 2006). Nevertheless, few forms depart from a "typical" oryzomyine molar bauplan, recognized

914 as early as Hershkovitz (1944): brachydont, bunodont, and pentalophodont. Pattonimus gen. nov.

915 is unique in this regard, and its dentition deserves further consideration.

916 Pattonimus gen. nov. molars have relatively higher crowns than that of most

917 oryzomyines. Hypsodonty “... is the evolutionary process that provides a longer wearing

918 surface by an increase in the depth of the tooth" (Hershkovitz, 1962: 88). If the classical

919 definition of hypsodonty is used, i.e. cheek tooth crown height exceeding its anteroposterior

920 length (Williams \& Kay, 2001), no oryzomyine can be considered as hypsodont and, in fact,

921 oryzomyines are typically treated as brachydont sigmodontines (e.g., Hershkovitz, 1960; Prado

922 \& Percequillo, 2018; Turvey et al., 2010; Musser et al., 1998). Weksler (2006: 44) indicated that

923 just “... the molars of Holochilus are hypsodont... Remaining [extant] oryzomyines have

924 bunodont and brachyodont molars." Nevertheless, it is clear that there is a considerable degree

925 of variation in crown elongation among members of the tribe, and several studies have used the

926 term hypsodont in a comparative sense. For example, Carleton \& Olson (1999: 25) discussed the

927 hypsodonty of the extinct Noronhomys, against that of Holochilus, indicating "The dissimilarity

928 in closure of the lingual folds may relate to the greater coronal hypsodonty seemingly

929 characteristic of Noronhomys.” Pardiñas (2008: Table 2), listed the genera Carletonomys,

930 Noronhomys, and Holochilus as hypsodont, but considered Pseudoryzomys and Lundomys as 
931 "higher crowned," and, by this action, highlighted the existence of some degree of variation in

932 hypsodonty within the tribe. When describing Drymoreomys, Percequillo, Weksler \& Costa

933 (2011: 365) stated that the genus has “... labial and lingual cusps high (molar nearly

934 hypsodont)." Pine, Timm \& Weksler (2012: 862) indicated that "Tanyuromys differs from both

935 Nectomys and Sigmodontomys in having much more complex molar patterns, less-hypsodont

936 molars." In fact, the tendency of Nectomys to have high-crowned molars, in comparison with

937 other oryzomyines, is largely recognized (see Ellerman, 1941: 361; Hershkovitz, 1944: 19). In

938 Mindomys, according to Percequillo (2015: 360), "the molars are pentalophodont and

939 moderately high-crowned." Comparative studies employing quantitative measures are necessary

940 to infer crown elongation among Oryzomyini, which apparently represents a gradient of

941 conditions and resists simplistic approaches, although, as was acutely highlighted by Carleton \&

942 Olson (1999: 25), “...an impression [the hypsodonty variation] that we cannot easily quantify,

943 however."

944 According to Hershkovitz (1962: 92), lamination “...is the process of transection of a

945 molar crown by confluence of a fold of one side of the tooth with another of the opposite side."

946 Technically, full lamination was not achieved within Cricetidae (cf. Ellerman, 1941; Stehlin \&

947 Schaub, 1951; Hershkovitz, 1962; Vorontsov, 1967), although an important degree of transverse

948 lamination (i.e., confluence of directly opposing folds; Hershkovitz 1962: 92) is observed in a

949 few taxa, such as the sigmodontine Irenomys (Teta \& Pardiñas, 2015). A tendency to lamination

950 is also recognized in several oryzomyines. Voss, Gómez-Laverde \& Pacheco (2002: 15),

951 describing Handleyomys, stated that "the principal labial flexi ...slant transversely across the

952 midline of the tooth to interpenetrate with much longer lingual flexi, resulting in the morphology

953 that Voss (1993: 20) termed 'incipient lophodonty' [in reference to the sigmodontine genus 
954 Delomys]." The lophodont condition of a molar refers to the presence of ridges or lophs

955 interconnecting the cusps; in many cases, lophs acquire the form of laminae (Mones, 1979). For

956 instance, the Otomyinae murids are characterized by an extreme lophodonty, distinguished with

957 the specific term loxodonty, displaying molars composed of numerous laminae or prisms

958 achieved via lamination (Denys, Michaux \& Hendey, 1987). Within Oryzomyini, lamination

959 reaches its high known expression in the fossil Noronhomys and in some species of Holochilus

960 (e.g., H. sciureus; Massoia, 1976; Voss \& Carleton, 1993; Carleton \& Olson, 1999). The

961 condition of the lamination displayed by these oryzomyines is what Hershkovitz (1962: 93)

962 described as "oblique [lamination]... confluence of a fold of one side with either the anterior or

963 posterior alternating fold of the opposite side."

964 Hypsodonty in sigmodontines is usually linked with planar occlusal surfaces and

965 simplification (see Ronez et al., 2020a, and the references cited therein). The latter process

966 constituted one of the main elements in Hershkovitz's (1962) understanding about molar

967 sigmodontine evolution which involved, almost axiomatically, the evolutionary transition from

968 complex (pentalophodont) to secondarily simplified (tetralophodont or derivates) molars.

969 Simplification implies the loss or obsolescence of occlusal structures, particularly the complex

970 mesoloph-mesostyle (i.e., tetralophodont molars), and also additional crests (e.g., anteroloph,

971 posteroloph; Hershkovitz, 1962: 76). Historically, Oryzomyini were treated as mostly

972 pentalophodont sigmodontines (Weksler, 2006, and references cited therein), but the

973 phylogenetic allocation of several tetralophodont genera as oryzomyines, namely Holochilus,

974 Lundomys, Pseudoryzomys, and Zygodontomys (Voss \& Carleton, 1993; Weksler, 2006)

975 compromised this traditional concept. The set of dentally simplified oryzomyines also includes

976 the fossil taxa Carletonomys, Noronhomys, and Reigomys (Machado et al., 2014). All 
977 phylogenetic evidence to date, including our results, points out that molar simplification operated

978 in at least two main lineages within the tribe: (1) in Zygodontomys, which is not closely related to

979 the remaining taxa and is placed at the base of oryzomyine diversification; and (2) in a clade

980 containing Holochilus, Lundomys, Pseudoryzomys, and the above mentioned fossil taxa, which

981 have been recovered consistently grouped (e.g., Carleton \& Olson, 1999; Weksler, 2006;

982 Machado et al., 2014). We propose here that Pattonimus gen. nov. represents an additional

983 oryzomyine lineage that is undergoing a morphological transition to a simplified occlusal

984 surface, coupled with incipient lamination, hypsodonty, and m3 compression.

985 In summary, we are convinced that the unique combination of dental traits displayed by

986 Pattonimus gen. nov. deserves generic recognition and that molar morphology diversity within

987 oryzoymines is markedly enlarged. Other arguable classificatory schemes could be to consider

988 these forms as members of already established genera such as Mindomys or Nephelomys.

989 However, this latter alternative hypothesis implies the acceptance that these taxa embrace an

990 extreme range of variability in the occlusal design of their molars. Speciose genera within

991 Oryzomyini, such as Cerradomys, Neacomys, the Nephelomys sensu stricto, or Oecomys, are

992 markedly conservative in molar morphology (e.g., Tavares, Pessôa \& Gonçalves, 2011;

993 Bonvicino, Casado \& Weksler, 2014; Hurtado \& Pacheco, 2017; Musser et al., 1998; Pardiñas

994 et al., 2016), which constitutes an accessory support to our preferred hypothesis.

995

996 Oryzomyine diversification in northern Andes and the aggregated value of Pattonimus gen.

997 nov.: The northern Andes have been long highlighted as an important region for the

998 diversification of the tribe Oryzomyini. The most significant contribution on this topic, prior to

999 the popularization of phylogenetic analysis, was based on the patterns of species richness in 
1000 South America, conducted by Reig (1986). Evaluating the species composition of the tribes of

1001 Sigmodontinae, he pointed out that the northern Andes were the "area of original differentiation"

1002 for the oryzomyines, a region from where this group originated and dispersed throughout the

1003 continent. As outlined by Prado \& Percequillo (2013), the composition of the tribe at that time

1004 was quite diverse, including several genera now assigned to the tribe Thomasomyini, and much

1005 of the diversity that has since been recognized.

1006 In fact, the northern portion of the Andean cordillera houses an incredible diversity of

1007 oryzomyine genera, such as Aegialomys, Handleyomys, "Handleyomys" (species of the alfaroi

1008 group; see Weksler, 2015), Melanomys, Mindomys, Microryzomys, Nephelomys, Oreoryzomys,

1009 and now Pattonimus gen. nov. Most of these lineages are considered as independent colonizers

1010 of the Andes, as they belong to different clades within the tribe and several of them do not share

1011 common histories, suggesting that dispersion is the most important process of tribal

1012 diversification in this region (Schenk \& Steppan, 2018). Nevertheless, the phylogenetic

1013 relationships recovered here, with Mindomys, Nephelomys and Pattonimus gen. nov. sharing a

1014 common ancestor within clade B, suggest that their generic and specific diversification took

1015 place locally. This clade would be a truly and unique Andean autochthonous radiation within

1016 Oryzomyini, with several species (Nephelomys, 12 species; Mindomys, one species; Pattonimus

1017 gen. nov., 2 to 4 species) evolving within these montane forests. Also, considering clade C, it is

1018 likely that the ancestor of Oreoryzomys and Microryzomys colonized this region once, but these

1019 genera are poorly diversified (three species only comprising both genera). This interesting issue

1020 deserves further exploration, but prima facie is not limited to oryzomyines. In fact, Ichthyomyini,

1021 one of the most singular expressions of the sigmodontine radiation, appear as a primary 
1022 autochthonous Andean radiation in northern South America (Voss, 1988) and it is likely that the

1023 same happened within the tribe Thomasomyini (Pacheco, 2015).

1024

1025 Pattonimus gen. nov. and overlooked sigmodontine diversity in northern Andes: In a

1026 worldwide appraisal to current mammalogy research, Ceballos \& Ehrlich (2009: 3) highlighted

1027 that "It appears that exploration of new regions has been the main factor for the discovery of as

1028 much as 40\% of the new species, such as the pygmy deer (Muntiacus putaoensis) in Bhutan, the

1029 Arunachal macaque (Macaca muzala) from the Himalaya foothills of northeast India, the

1030 Amazonian basin monkeys, and most of the new Philippines species... The exploration of new

1031 regions has been based on both the use of either new techniques... or traditional techniques,

1032 such as pitfall traps, which have yielded specimens of 8 new species of shrew-tenrecs from

1033 Madagascar since 1988." The case of Pattonimus gen. nov. is a suitable example of what

1034 "traditional techniques" of collection can achieve when applied in unexplored Andean regions.

1035 We are dealing with a new genus and maybe four new species, a noticeable increment for a

1036 mammal group understood as moderately well-known (Patton, Pardiñas \& D'Elía, 2015).

1037 Continuous sampling is crucial, even in well sampled areas, as testifies the description of two

1038 new genera and species in the Atlantic Forest of São Paulo, Paraná, Santa Catarina and the rocky

1039 outcrops of the Cerrado in Minas Gerais, in southeastern Brazil, in the last ten years, namely

1040 Drymeoreomys albimaculatus (Percequillo, Weksler \& Costa, 2011) and Calassomys apicalis

1041 (Pardiñas et al., 2014).

1042 After more than two centuries of active mammalogy research (Tirira, 2014), intensive field

1043 work was conducted in few Ecuadorian places. Examples for those places in the eastern Andes

1044 are Papallacta (Voss, 2003), Guandera Biological Reserve (Lee et al., 2015), Sangay National

1045 Park (Brito \& Ojala Barbour, 2016), Yacuri National Park (Lee et al., 2018); and in the western 
1046 Andes are Cajas National Park (Barnett, 1999), Otonga Reserve (Jarrín, 2001; Pinto et al.,

1047 2018), Pululahua Geobotanical Reserve (Curay, Romero \& Brito, 2019), and Polylepis Forest

1048 (Ojala-Barbour, Brito \& Teska, 2019). The interest in complementing biodiversity studies has

1049 led to expeditions to little-known locations, such as the Reserva Drácula and also triggered

1050 revisions of museum specimens. These approaches have retrieved several recent additions to the

1051 Ecuadorian sigmodontine fauna (e.g., Rhagomys longilingua, see Medina et al., 2017;

1052 Amphinectomys savamis, see Chiquito \& Percequillo, 2016; Nectomys saturatus, see Chiquito \&

1053 Percequillo, 2019), and also led to the description of new biological entities (e.g., Rhipidomys

1054 albujai, see Brito et al., 2017; Tanyuromys thomasleei, see Timm, Pine \& Hanson, 2018;

1055 Thomasomys salazari, see Brito et al., 2019; Ichthyomys pinei, see Fernández de Córdova et al.,

1056 2020). In this same way, recent surveys in isolated Ecuadorian mountain systems, such as

1057 Cordillera del Cóndor and Kutukú, are revealing several novel species for monotypic (e.g.,

1058 Mindomys) or speciose genera (e.g., Neacomys, Rhipidomys and Thomasomys), which are still in

1059 the process of publication. Such flourishing richness surely will reorganize part of our

1060 understanding of Neotropical cricetids. This context highlights the urgency to establish rational

1061 and comprehensive programs of inventory and collection as well as to improve the access of

1062 scholars to these resources.

1063

1064 CONCLUSIONS

1065 A new genus, Pattonimus gen. nov., is added to Oryzomyini. With at least three species, two of

1066 them described here (Pattonimus ecominga sp. nov. and P. musseri sp. nov.), this new cricetid

1067 appears as an endemic form of the montane forest of southern Chocó biogeographic region in

1068 western Ecuador and Colombia. Phylogenetic analyses based on combined morphological and 
1069 genetic evidence resolve Pattonimus sp. nov. as sister to Mindomys, another Chocoan endemic.

1070 Molar morphology highlights the singularity of the new genus by combining moderately

1071 hypsodont teeth with simplified occlusal design and a distinct tendency to lamination. Since

1072 Pattonimus sp. nov. is a novel taxon that has emerged from recent field studies, this is a clear

1073 indication of our still fragmentary knowledge of rodent communities in the Andes.

1074

1075 ACKNOWLEDGEMENTS

1076 To J. Robayo, L. Jost, and H. Schneider of Basel Botanical Garden and Rainforest Trust; to the

1077 graduate biologists J. Curay, R. Vargas, R. Garcia, C. Bravo, S. Pozo (the "Minion” team), and

1078 C. Nivelo, for invaluable field assistance; to the rangers of EcoMinga, especially H. Yela, T.

1079 Recalde, J. M. Loaiza, and D. Meneses for their deep efforts with field logistics; to D. Inclán and

1080 F. Prieto of INABIO, for their sponsorship and permanent support. N. Cazzaniga guided us in

1081 nomenclatorial aspects. C. Galliari helped in multivariate analyses. J.P. Carrera (MEPN), S.

1082 Burneo (QCAZ), J. Decher (ZFMK), and R. Hutterer (ZFMK) allowed access to the mammal

1083 collections under their charge. R. A. Martin generously read the manuscript and corrected the

1084 grammar and spelling. We are deeply indebted to the above-mentioned persons and institutions.

1085

1086 Supplemental Information

1087

Supplemental Information S1. —Pitfall line, the main technique for capturing small

1088 mammals in this study (Reserva Drácula; photo: J. Brito).

1089 Supplemental Information S2. — List of studied specimens.

1090 Supplemental Information S3. - The morphological character matrix 103. 
Supplemental Information S4. - Access numbers and vouchers for taxa used in the

1092 phylogenetic analyses.

1093 Supplemental Information S5. - Phylogenetic relationships of the tribe Oryzomyini.

1094 Best tree from ML analyses from analyses of DNA sequences of mitochondrial Cytb (A) and

1095 nuclear IRBP (B) genes. Numbers below branches are ML bootstrap support and posterior

1096 probability values. Clades are indicated by letters (A to D). The dash line indicated the position

1097 of new taxa.

1098 Supplemental Information S6. - Substitution saturation plot. The x-axes GTR for Cytb

1099 and K80 for IRBP distance is based on the GTR for Cytb and K80 for IRBP substitution model

1100 and is expected to increase linearly with divergence time. The vertical axes is for the observed

1101 proportion of transitions (s) and transversions (v), respectively. Graphs A, B and C represent the

1102 results of saturation of the first, second and third positions of the mitochondrial gene Cytb (Cytb)

1103 and graphs D, E and F represent the results of saturation of the first, second and third positions of

1104 the nuclear gene IRBP.

1105 Supplemental Information S7. - Upper and lower molar roots of: A, B, Pattonimus

1106 ecominga sp. nov. (MECN 5928, holotype); C, D, Mindomys hammondi (BMNH 13.10.24.58,

1107 holotype); and E, F, Nephelomys auriventer (MECN 5812). Abbreviations: a = accessory root; 1,

1108 2, 3 = main roots; M1, M2, M3 = upper molars; m1, m2, m3 = lower molars.

1109 Supplemental Information S8. - Results of UPGMA clustering of Mahalanobis

1110 distances among two geographic samples (molar measurements transformed to natural

1111 logarithms) of the new genus; individuals are labelled by museum collection numbers with the

1112 addition of "e" = Reserva Drácula, and "m" = Reserva Río Manduriacu (terminals with * denote

1113 holotypes). 
1114 Supplemental Information S9. - PCA including 10 individuals from Reserva Drácula

1115 (labelled with “e”) and 2 individuals from Reserva Río Manduriacu (labelled with “m”); original

1116 matrix composed of 38 external and craniodental measurements, transformed to their natural

1117 logarithms.

1118 Supplemental Information S10. — Sagittal plane and coronal cross section of cranium

1119 and 3D representations of turbinal bones of: A, C, Pattonimus ecominga sp. nov. (MECN 5928,

1120 holotype), and B, D, Mindomys hammondi (BMNH 13.10.24.58, holotype). Abbreviations: etI =

1121 ethmoturbinal I, etII = ethmoturbinal II, etIII = ethmoturbinal III, ft1 $=$ frontoturbinal $1, \mathrm{ft} 2=$

1122 frontoturbinal 2 , it $=$ interturbinal, $1 \mathrm{~s}=$ lamina semicircularis, $\mathrm{mt}=$ maxilloturbinal, $\mathrm{nt}=$

1123 nasoturbinal, Olfa $=$ olfactory turbinals, Respi $=$ respiratory turbinals.

1124 Supplemental Information S11. - Pattonimus ecominga sp. nov. (Reserva Drácula,

1125 Carchi, Ecuador): dry skin in dorsal, ventral, and lateral views (MECN 5928, holotype).

1126 Supplemental Information S12. - A, Cloud forest at Reserva Drácula, habitat of

1127 Pattonimus ecominga sp. nov., and B, the team (from left to right, U. Pardiñas, R. García, J.

1128 Curay, S. Pozo, and C. Nivelo) processing the harvest at Drácula basecamp (photos: J. Brito).

1129 Supplemental Information S13. - Short video recording diurnal activity of a specimen

1130 of Pattonimus ecominga sp. nov. in the wild (MECN 6034; adult female). Video by: Jorge Brito.

1131 Supplemental Information S14. - Pattonimus musseri sp. nov. (Reserva Río

1132 Manduriacu, Imbabura, Ecuador): dry skin in dorsal, ventral, and lateral views (MEPN 12605,

1133 holotype).

1134 Supplemental Information S15. - Pattonimus sp. from Reserva Otonga (QCAZ 8720;

1135 Cotopaxi, Ecuador): cranium in ventral view (top), and hemimandible in dorsal and labial views

1136 (bottom). 


\section{REFERENCES}

1139 Abreu-Junior EF, Brennand PGG, Chiquito EA, Jorge-Rodrigues CR, Libardi GS, Prado JR,

1140 Percequillo AR. 2012. Dimorfismo sexual na tribo Oryzomyini. In: Freitas TRO, Vieira

1141 EM, eds. Mamíferos do Brasil: genética, sistemática, ecologia e conservação. Rio de

1142 Janeiro: Sociedade Brasileira de Mastozoologia, 115-134.

1143 Albuja L, Almendáriz A, Barriga R, Montalvo LD, Cáceres F, Román JL. 2012. Fauna de

1144 Vertebrados del Ecuador. Quito: Instituto de Ciencias Biológicas, Escuela Politécnica

$1145 \quad$ Nacional.

1146 Almendra AL, González-Cózatl FX, Engstrom MD, Rogers DS. 2018. Evolutionary

1147 relationships and climatic niche evolution in the genus Handleyomys (Sigmodontinae:

$1148 \quad$ Oryzomyini). Molecular Phylogenetics and Evolution 128:12-25. DOI

$1149 \quad$ 10.1016/j.ympev.2018.06.018.

1150 Arellano E, Gonzáles-Cózalt F, Rogers D. 2006. Molecular systematics of Middle American

1151 harvest mice Reithrodontomys (Muridae), estimated from mitochondrial cytochrome b

1152 gene sequences. Molecular Phylogenetics and Evolution 37:529-540. DOI

$1153 \quad$ 10.1016/j.ympev.2005.07.021.

1154 Barnett AA. 1999. Small mammals of the Cajas Plateau, southern Ecuador: ecology and natural

1155 history. Bulletin of the Florida Museum of Natural History 42:161-217.

1156 Bilton DT, Jaarola M. 1996. Isolation and purification of vertebrate DNAs. In: Clapp JP, ed.

1157 Species diagnostics protocols: PCR and other nucleic acid methods in molecular biology.

1158 Totowa: Humana Press, 25-37. 
1159 Bonvicino CR, Casado F, Weksler M. 2014. A new species of Cerradomys (Mammalia:

1160 Rodentia: Cricetidae) from Central Brazil, with remarks on the taxonomy of the genus.

1161 Zoologia (Curitiba) 31:525-540 DOI 10.1590/S1984-46702014000600002.

1162 Brandt RS, Pessôa LM. 1994. Intrapopulational variability in cranial characters of Oryzomys

1163 subflavus (Wagner, 1842) (Rodentia: Cricetidae), in northeastern Brazil. Zoologischer

$1164 \quad$ Anzeiger 233:45-55.

1165 Brito J, Arguero A. 2016. Nuevas localidades para tres especies de mamíferos pequeños

1166 (Rodentia: Cricetidae) escasamente conocidos en Ecuador. Mastozoología Neotropical

$1167 \quad 23: 521-527$.

1168 Brito J, Tinoco N, Chávez D, Moreno-Cárdenas P, Batallas D, Ojala-Barbour R. 2017. New

1169 species of arboreal rat of the genus Rhipidomys (Cricetidae, Sigmodontinae) from Sangay

1170 National Park, Ecuador. Neotropical Biodiversity 3:65-79 DOI

$1171 \quad 10.1080 / 23766808.2017 .1292755$.

1172 Brito J, Tinoco N, Curay J, Vargas R, Reyes-Puig C, Romero V, Pardiñas UFJ. 2019. Diversidad

1173 insospechada en los Andes de Ecuador: filogenia del grupo "cinereus" de Thomasomys y

1174 descripción de una nueva especie (Rodentia, Cricetidae). Mastozoología Neotropical 26:1-

22 DOI $1175.31687 /$ saremMN.19.26.2.0.04

1176 Brito J, Ojala-Barbour R. 2016. Mamíferos no voladores del Parque Nacional Sangay, Ecuador.

1177 Papéis Avulsos de Zoología 56:45-61 DOI 10.1590/0031-1049.2016.56.05.

1178 Brooks T, Mittermeier M, Mittermeier RA, Da Fonseca CG, Rylands GA, Konstant AB, Flyck P,

1179 Pilgrim J, Oldfield S, Magin G, Hilton-Taylor C. 2002. Habitat loss and extinction in the

1180 hotspots of biodiversity. Conservation Biology 16:909-923. 
1181 Cadena A, Anderson RP, Rivas-Pava P. 1998. Colombian mammals from the Chocoan slopes of

1182 Nariño. Occasional Papers Museum of Texas Tech University 180:1-15.

1183 Carleton MD, Musser CG.1989. Systematic studies of Oryzomyine rodents (Muridae,

1184 Sigmodontinae): A synopsis of Microryzomys. Bulletin of the American Museum of

$1185 \quad$ Natural History 191:1-83.

1186 Carleton MD, Olson S. 1999. Amerigo Vespucci and the rat of Fernando de Noronha: a new

1187 genus and species of Rodentia (Muridae: Sigmodontinae) from a volcanic island off

1188 Brazil's continental shelf. American Museum Novitates 3256:1-59.

1189 Carleton MD. 1973. A survey of gross stomach morphology in New World Cricetinae (Rodentia,

1190 Muroidea), with comments on functional interpretations. Miscellaneous Publications,

1191 Museum of Zoology, University of Michigan 146:1-43.

1192 Carleton MD. 2009. They sort out like nuts and bolts: a scientific biography of Guy G. Musser.

1193 In: Voss RS, MD Carleton, eds. Systematic mammalogy: contributions in honor of Guy G.

1194 Musser. Bulletin of the American Museum of Natural History 331:1-450.

1195 Ceballos G, Ehrlich PR. 2009. Discoveries of new mammal species and their implications for

1196 conservation and ecosystem services. PNAS 106:3841-3846 DOI

$1197 \quad$ 10.1073/pnas.0812419106.

1198 Cerón C, Palacios W, Valencia R, Sierra R. 1999. Las formaciones naturales de la Costa del

1199 Ecuador. In: Sierra R. ed. Propuesta preliminar de un sistema de clasificación de

1200 vegetación para el Ecuador continental. Quito: Proyecto INEFAN/GERF-BIRF and

$1201 \quad$ Ecociencia.

1202 Chiquito EA, Percequillo AR. 2019. The taxonomic status of Nectomys saturatus Thomas, 1897

1203 (Cricetidae: Sigmodontinae). Zootaxa 4550:321-339 DOI 10.11646/zootaxa.4550.3.2. 
1204 Chiquito EA, Percequillo AR. 2016. On the rare species Amphinectomys savamis Malygin 1994

1205 (Rodentia, Cricetidae, Sigmodontinae): new record and morphological considerations.

1206 Mammalia 81:531-536 DOI 10.1515/mammalia-2016-0101.

1207 Costa BMA, Geise L, Pereira LG, Costa LP. 2011. Phylogeography of Rhipidomys (Rodentia:

1208 Cricetidae: Sigmodontinae) and description of two new species from southeastern Brazil.

1209 Journal of Mammalogy 92:945-962 DOI 10.1644/10-MAMM-A-249.1.

1210 Curay J, Romero V, Brito J. 2019. Small non-volant mammals of the Reserva Geobotánica

1211 Pululahua, Ecuador. Mammalia 83: 574-580 DOI 10.1515/mammalia-2018-0131.

1212 Denys C, Michaux J, Hendey B. 1987. An example of evolutionary parallelism? The

1213 Euryotomys-Otomys case in tropical Africa (Mammalia, Rodentia). Comptes Rendus de l'

$1214 \quad$ Academie des Sciences Serie II 305:1389-1395.

1215 Ellerman JR. 1941. The families and genera of living rodents. Vol. 2. Family Muridae. London:

1216 Trustees of the British Museum (Natural History).

1217 Farris JS, Albert VA, Källersjö M, Lipscomb D, Kluge AG. 1996. Parsimony jackknifing

1218 outperforms neighbor-joining. Cladistics 12:99-124. DOI 10.1111/j.1096-

$1219 \quad$ 0031.1996.tb00196.x.

1220 Farris JS. 1983. The logical basis of phylogenetic analysis. In: Platnick NI, Funk VA, eds.

1221 Advances in cladistics, volume 2: Proceedings of the second meeting of the Willi Hennig

$1222 \quad$ Society. New York: Columbia University Press, 7-36.

1223 Felsenstein J. 1981. Evolutionary trees from gene frequencies and quantitative characters:

1224 Finding maximum likelihood estimates. Evolution 35:1229-1242 DOI 10.1111/j.1558-

$1225 \quad$ 5646.1981.tb04991.x. 
1226 Felsenstein J. 1985. Confidence limits on phylogenies: An approach using the bootstrap.

1227 Evolution 39:783-791 DOI 10.1111/j.1558-5646.1985.tb00420.x.

1228 Fernández de Córdova JF, Nivelo-Villavicencio C, Reyes-Puig C, Pardiñas UFJ, Brito J. 2020. A

1229 new species of crab-eating rat of the genus Ichthyomys, from Ecuador (Rodentia,

1230 Cricetidae, Sigmodontinae). Mammalia 84:377-391 DOI 10.1515/mammalia-2019-0022.

1231 Guayasamin JM, Cisneros-Heredia DF, Vieira J, Kohn S, Gavilanes G, Lynch RL, Hamilton PS,

1232 Maynard RJ. 2019. A new glassfrog (Centrolenidae) from the Chocó-Andean Río

1233 Manduriacu Reserve, Ecuador, endangered by mining. PeerJ 7:e6400 DOI

$1234 \quad$ 10.7717/peerj.6400.

1235 Hammer Ø. 1999-2018. PAST. PAleontological STatistics. Version 3.21. Reference Manual.

1236 Oslo: Natural History Museum, University of Oslo.

1237 Hershkovitz P. 1944. Systematic review of the Neotropical water rats of the genus Nectomys

1238 (Cricetinae). Miscellaneous Publications, University of Michigan, Museum of Zoology

$1239 \quad 58: 1-101$.

1240 Hershkovitz P. 1960. Mammals of northern Colombia. Preliminary Report nº . 8: Arboreal Rice

1241 Rats, a systematic revision of the subgenus Oecomys, genus Oryzomys. Proceedings of the

$1242 \quad$ United States National Museum 110:513-568.

1243 Hershkovitz P. 1962. Evolution of Neotropical cricetine rodents (Muridae) with special reference 1244 to the phyllotine group. Fieldiana Zoology 46:1-524.

1245 Huelsenbeck JP, Ronquist F, Nielsen R, Bollback JP. 2001. Bayesian inference of phylogeny and

1246 its impact on evolutionary biology. Science 294:2310-2314 DOI 10.1126/science.1065889.

1247 Huelsenbeck JP, Ronquist F. 2001. MRBAYES: Bayesian inference of phylogenetic trees.

$1248 \quad$ Bioinformatics 17:754-755. 
1249 Hurtado N, Pacheco V. 2017. Revision of Neacomys spinosus (Thomas, 1882) (Rodentia:

1250 Cricetidae) with emphasis on Peruvian populations and the description of a new species.

1251 Zootaxa 4242:401-440. DOI 10.11646/zootaxa.4242.3.1.

1252 Jansa SA, Voss RS. 2000. Phylogenetic studies on didelphid marsupials I. Introduction and

1253 preliminary results from nuclear IRBP gene sequences. Journal of Mammalian Evolution

1254 7:43-77. DOI 10.1023/A:1009465716811.

1255 Jarrín P. 2001. Mamíferos en la niebla Otonga, un bosque nublado del Ecuador. Quito: Museo

1256 de Zoología, Centro de Biodiversidad y Ambiente, Pontificia Universidad Católica del

1257 Ecuador.

1258 Kumar S, Stecher G, Tamura K. 2016. MEGA7: molecular evolutionary genetics analysis

1259 version 7.0 for bigger datasets. Molecular Biology and Evolution 33:1870-1874 DOI

$1260 \quad 10.1093 / \mathrm{molbev} / \mathrm{msw} 054$.

1261 Lanfear R, Calcott B, Ho SY, Guindon S. 2012. PartitionFinder: combined selection of

1262 partitioning schemes and substitution models for phylogenetic analyses. Molecular Biology

1263 and Evolution 29:1695-1701 DOI 10.1093/molbev/mss020.

1264 Lee TE, Ritchie AR, Vaca-Puente S, Brokaw JM, Camacho MA, Burneo SF. 2015. Small

1265 mammals of Guandera Biological Reserve, Carchi Province, Ecuador and comparative

1266 Andean small mammal ecology. Occasional Papers, Museum of Texas Tech University

$1267 \quad 334: 1-17$.

1268 Lee Jr, TE, Tinoco N, Maya JF, Gomez D, Hanson JD, Camacho MA, Burneo SF. 2018.

1269 Mammals of Yacuri National Park, Loja, Province, Ecuador. Occasional Papers, Museum

$1270 \quad$ of Texas Tech University 357:1-17. 
1271 Lewis PO. 2001. A likelihood approach to estimating phylogeny from discrete morphological 1272 character data. Systematic Biology 50:913-925.

1273 Machado LF, Leite YL, Christoff AU, Giugliano LG. 2014. Phylogeny and biogeography of 1274 tetralophodont rodents of the tribe Oryzomyini (Cricetidae: Sigmodontinae). Zoologica $1275 \quad$ Scripta 43:119-130 DOI 10.1111/zsc.12041.

1276 Maestri R, Patterson BD. 2016. Patterns of species richness and turnover for the South American 1277 rodent fauna. PLoS ONE 11: e0151895 DOI 10.1371/journal.pone.0151895.

1278 Martinez Q, Lebrun R, Achmadi AS, Esselstyn JA, Evans AR, Heaney LR, Miguez RP, Rowe 1279 KC, Fabre PH. 2018. Convergent evolution of an extreme dietary specialisation, the 1280 olfactory system of worm-eating rodents. Scientific Reports 8:17806 DOI 10.1038/s41598$1281 \quad 018-35827-0$.

1282 Massoia E. 1976. Mammalia. In: Ringuelet R, ed. Fauna de agua dulce de la República 1283 Argentina. Buenos Aires: Fundación Editorial Ciencia y Cultura, 1-128.

1284 Medina CE, Díaz DR, Pino K, Pari A, Zeballos H. 2017. New locality records of Rhagomys 1285 longilingua Luna \& Patterson, 2003 (Rodentia: Cricetidae) in Peru. Check List 13: 1-7 $1286 \quad$ DOI $10.15560 / 13.3 .2136$.

1287 Miller M, Pfeiffer W, Schwartz T. 2010. Creating the CIPRES Science Gateway for inference of 1288 large phylogenetic trees. New Orleans: Gateway Computing Environments Workshop $1289 \quad$ (GCE).

1290 Mittermeier RA, Myers N, Mittermeier CG, Robles G. 1999. Hotspots: Earth's biologically 1291 richest and most endangered terrestrial ecoregions. CEMEX, SA, Agrupación Sierra 1292 Madre, SC. 
1293 Mones A. 1979. Los dientes de los vertebrados: una introducción a su estudio. Montevideo:

$1294 \quad$ Universidad de la Republica, Facultad de Humanidades y Ciencias.

1295 Musser GG, Carleton MD, Brothers E, Gardner AL. 1998. Systematic studies of oryzomyine

1296 rodents (Muridae, Sigmodontinae): diagnoses and distributions of species formerly

1297 assigned to Oryzomys "capito." Bulletin of the American Museum of Natural History

$1298 \quad 236: 1-376$.

1299 Myers N, Mittermeier RA, Mittermeier CG, Da Fonseca GA, Kent J. 2000. Biodiversity hotspots

$1300 \quad$ for conservation priorities. Nature 403:853.

1301 Ojala-Barbour R, Brito J, Teska WR. 2019. A comparison of small mammal communities in two

1302 High-Andean Polylepis woodlands in Ecuador. ACI Avances en Ciencias e Ingenierías

$1303 \quad$ 11:208-221 DOI 10.18272/aci.v11i2.516.

1304 Pacheco V. 2015. Genus Thomasomys Coues, 1884. In: Patton JL, Pardiñas UFJ, D’Elía G, eds.

$1305 \quad$ Mammals of South America, Vol. 2: Rodents, 617-682.

1306 Pardiñas UFJ. 2008. A new genus of oryzomyine rodent (Cricetidae: Sigmodontinae) from the

1307 Pleistocene of Argentina. Journal of Mammalogy 89:1270-1278 DOI 10.1644/07-

1308 MAMM-A-099.1.

1309 Pardiñas UFJ, Lessa G, Teta P, Salazar-Bravo J, Câmara EM. 2014. A new genus of

1310 sigmodontine rodent from eastern Brazil and the origin of the tribe Phyllotini. Journal of

1311 Mammalogy 95:201-215 DOI 10.1644/13-MAMM-A-208.

1312 Pardiñas UFJ, Myers P, León-Paniagua L, Ordóñez Garza N, Cook J, Kryštufek B, Haslauer R,

1313 Bradley R, Shenbrot G, Patton J. 2017. Family Cricetidae (true hamsters, voles, lemmings

1314 and New World rats and mice). In: Wilson DE, Lacher TE, and Mittermeier RA, eds. 
1315 Handbook of the Mammals of the World, Volume 7. Rodents II. Barcelona: Lynx Editions, $1316 \quad 204-279$.

1317 Pardiñas UFJ, Teta P, Salazar-Bravo J, Myers P, Galliari CA. 2016. A new species of arboreal 1318 rat, genus Oecomys (Rodentia, Cricetidae) from Chaco. Journal of Mammalogy 97:1177$1319 \quad 1196$ DOI 10.1093/jmammal/gyw070.

1320 Patton JL, Pardiñas UFJ, D’Elía G, eds. 2015. Mammals of South America, Vol. 2: Rodents. 1321 Chicago: University of Chicago Press.

1322 Percequillo AR. 2015. Genus Mindomys Weksler, Percequillo and Voss, 2006. In: Patton JL, 1323 Pardiñas UFJ, D’Elía G, eds. Mammals of South America, Vol. 2: Rodents, 330-361.

1324 Percequillo AR, Weksler M, Costa LP. 2011. A new genus and species of rodent from the 1325 Brazilian Atlantic Forest (Rodentia: Cricetidae: Sigmodontinae: Oryzomyini), with 1326 comments on oryzomyine biogeography. Zoological Journal of the Linnean Society 1327 161:357-390 DOI 10.1111/j.1096-3642.2010.00643.x.

1328 Pine RH, Timm RM, Weksler M. 2012. A newly recognized clade of trans-Andean Oryzomyini

1329 (Rodentia: Cricetidae), with description of a new genus. Journal of Mammalogy 93:851$1330 \quad 870$ DOI 10.1644/11-MAMM-A-012.1.

1331 Pinto CM, Ojala-Barbour R, Brito J, Menchaca A, Carvalho AL, Weksler M, Lee Jr. TE. 2018.

1332 Rodents of the eastern and western slopes of the Tropical Andes: phylogenetic and 1333 taxonomic insights using DNA barcodes. Therya 9:15-27 DOI 10.12933/therya-18-430.

1334 Prado JR, Percequillo AR. 2013. Geographic distribution of the genera of the tribe Oryzomyini 1335 (Rodentia: Cricetidae: Sigmodontinae) in South America: patterns of distribution and 1336 diversity. Arquivos de Zoologia 44:1-120 DOI 10.11606/issn.2176-7793.v44i1p1-120. 
1337 Prado JR, Percequillo AR. 2018. Systematic studies of the genus Aegialomys Weksler et al.,

13382006 (Rodentia: Cricetidae: Sigmodontinae): geographic variation, species delimitation,

1339 and biogeography. Journal of Mammalian Evolution 25:71-118 DOI 10.1007/s10914-016-

$1340 \quad 9360-y$.

1341 Prado JR, Brennand PG, Godoy LP, Libardi GS, de Abreu-Júnior EF, Roth PR, Percequillo AR.

1342 2015. Species richness and areas of endemism of oryzomyine rodents (Cricetidae,

1343 Sigmodontinae) in South America: an NDM/VNDM approach. Journal of Biogeography

1344 42:540-551 DOI 10.1111/jbi.12424.

1345 Reig OA. 1977. A proposed unified nomenclature for the enameled components of the molar

1346 teeth of the Cricetidae (Rodentia). Journal of Zoology 181:227-241.

1347 Reig OA. 1984. Distribuição geográfica e história evolutiva dos roedores muroideos

1348 sulamericanos (Cricetidae: Sigmodontinae). Revista Brasileira de Genética 7:333-365.

1349 Reig OA. 1986. Diversity patterns and differentiation of high Andean rodents. In: Vuilleumier F,

1350 Monasterio M, eds. High Altitude Tropical Biogeography. Oxford: Oxford University

$1351 \quad$ Press, Oxford, 404-439.

1352 Rodríguez-Robles JA, Greene HW. 2005. Genes, rats, and sinking boats: A biographical

1353 perspective on James L. Patton. In: Lacey E, Myers, P. eds. Mammalian diversification.

1354 From chromosomes to phylogeography (a celebration of the career of James L. Patton).

1355 California: University of California Publications, Zoology, 5-56.

1356 Ronez C, Barbiere F, De Santis L, Pardiñas UFJ. 2020a. Third upper molar enlargement in

1357 sigmodontine rodents (Cricetidae): morphological disparity and evolutionary convergence.

1358 Mammalia 84:278-282 DOI 10.1515/mammalia-2019-0031. 
1359 Ronez C, Brito J, Hutterer R, Martin RA, Pardiñas UFJ. 2020b. Tribal allocation and

1360 biogeographical significance of one of the largest sigmodontine rodent, the extinct

1361 Galápagos Megaoryzomys (Cricetidae). Historical Biology DOI

$1362 \quad 10.1080 / 08912963.2020 .1752202$.

1363 Ronquist F, Huelsenbeck JP. 2003. MrBayes 3: Bayesian phylogenetic inference under mixed

1364 models. Bioinformatics 19:1572-1574.

1365 Roy BA, Zorrilla M, Endara L, Thomas DC, Vandegrift R, Rubenstein JM, Policha T, Ríos-

1366 Touma B, Read M. 2018. New mining concessions could severely decrease biodiversity

1367 and ecosystem services in Ecuador. Tropical Conservation Science 11:1-20 DOI

$1368 \quad 10.1177 / 1940082918780427$.

1369 Schenk JJ, Steppan SJ. 2018. The role of geography in adaptive radiation. The American Naturalist 192:415-431 DOI 10.1086/699221.

1371 Sikes RS, \& Animal Care and Use Committee of the American Society of Mammalogists. 2016.

1372 Guidelines of the American Society of Mammalogists for the use of wild mammals in

1373 research and education. Journal of Mammalogy 97:663-688 DOI

$1374 \quad$ 10.1093/jmammal/gyw078.

1375 Stamatakis A. 2006. RAxML-VI-HPC: maximum likelihood-based phylogenetic analyses with

1376 thousands of taxa and mixed models. Bioinformatics 22:2688-2690 DOI

$1377 \quad$ 10.1093/bioinformatics/btl446.

1378 Stehlin HG, Schaub S. 1951. Die Trigonodontie der simplicidentaten Nager. Schweizerische

1379 Palaontologische Abhandlungen 67:1-385.

1380 Steppan S. 1995. Revision of the tribe Phyllotini (Rodentia: Sigmondontinae), with a

1381 phylogenetic hypothesis for the Sigmodontinae. Revisión de la tribu Phyllotini (Rodentia: 
1382 Sigmondontinae), con una hipótesis filogenética para los Sigmodontinae. Fieldiana

1383 Zoology 1464:1-112.

1384 Swofford DL, Olsen GJ, Waddell PJ, Hillis DM. 1996. Phylogenetic inference. In: Hillis DM,

1385 Moritz C, Mable BK, eds. Molecular Systematics. 2nd edition. Sinauer: Sunderland, Mass,

$1386 \quad 407-514$.

1387 Swofford DL. 2002. PAUP: phylogenetic analysis using parsimony, version 4.0 b10.

1388 Teta P, Pardiñas UFJ. 2015. Genus Irenomys Thomas, 1919. In: Patton JL, Pardiñas UFJ, D’Elía

1389 G, eds. Mammals of South America. Vol. 2. Rodents. University of Chicago Press,

$1390 \quad$ Chicago, pp 89-92.

1391 Tavares WC, Pessôa LM, Gonçalves PR. 2011. New species of Cerradomys from coastal sandy

1392 plains of southeastern Brazil (Cricetidae: Sigmodontinae). Journal of Mammalogy 92:645-

$1393 \quad 658$ DOI 10.1644/10-MAMM-096.1.

1394 Thomas O. 1913. New mammals from South America. Annals and Magazine of Natural History

$1395 \quad 12: 567-574$.

1396 Timm RM, Pine RH, Hanson JD. 2018. A new species of Tanyuromys Pine, Timm, and Weksler,

2012 (Cricetidae: Oryzomyini), with comments on relationships within the Oryzomyini.

1398 Journal of Mammalogy 99:608-623 DOI 10.1093/jmammal/gyy042.

1399 Tirira DG. 2014. Historia de la Mastozoología en Ecuador. In: Ortega J, Martínez JL, Tirira DG,

$1400 \quad$ eds. Historia de la Mastozoología en Latinoamérica, las Guayanas y el Caribe. Quito and

1401 México, DF: Editorial Murciélago Blanco y Asociación Ecuatoriana de Mastozoología, $1402 \quad 205-244$.

1403 Tribe CJ. 1996. The neotropical rodent genus Rhipidomys (Cricetidae: Sigmodontinae): a 1404 taxonomic revision. D. Phil. Thesis, University College London. 
1405 Turvey ST, Brace S, Weksler M. 2012. A new species of recently extinct rice rat (Megalomys)

1406 from Barbados. Mammalian Biology 77:404-413 DOI 10.1016/j.mambio.2012.03.005.

1407 Turvey ST, Weksler M, Morris EL, Nokkert M. 2010. Taxonomy, phylogeny, and diversity of

1408 the extinct Lesser Antillean rice rats (Sigmodontinae: Oryzomyini), with description of a

1409 new genus and species. Zoological Journal of the Linnean Society 160:748-772 DOI

$1410 \quad 10.1111 / \mathrm{j} .1096-3642.2009 .00628 . x$.

1411 Valencia-Pacheco E, Avaria-Llautureo J, Muñoz-Escobar C, Boric-Bargetto D, Hernández CE.

1412 2011. Patrones de distribución geográfica de la riqueza de especies de roedores de la Tribu

1413 Oryzomyini (Rodentia: Sigmodontinae) en Sudamérica: Evaluando la importancia de los

1414 procesos de colonización y extinción. Revista Chilena de Historia Natural 84:365-377

$1415 \quad$ DOI $10.4067 / \mathrm{S} 0716-078 X 2011000300005$.

1416 Vorontsov NN. 1967. Evolution of the alimentary system in myomorph rodents. (In Russian).

1417 Nauka: Siberian Branch, Novosibirsk.

1418 Voss RS. 1988. Systematics and ecology of ichthyomyine rodents (Muroidea): patterns of

1419 morphological evolution in a small adaptive radiation. Bulletin of the American Museum of

$1420 \quad$ Natural History 188:262-493.

1421 Voss RS. 1991. An introduction to the Neotropical muroid rodent genus Zygodontomys. Bulletin 1422 of the American Museum of Natural History 210:1-120.

1423 Voss RS. 2003. A new species of Thomasomys (Rodentia: Muridae) from Eastern Ecuador, with

1424 remarks on mammalian diversity and biogeography in the Cordillera Oriental. American

$1425 \quad$ Museum Novitates 3421:1-47. 
1426 Voss RS, Carleton MD. 1993. A new genus for Hesperomys molitor Winge and Holochilus

1427 magnus Hershkovitz, with comments on phylogenetic relationships and oryzomyine

1428 monophyly. American Museum Novitates 3085:1-39.

1429 Voss RS, Weksler M. 2009. On the taxonomic status of Oryzomys curasoae McFarlane and

1430 Debrot, 2001, (Rodentia: Cricetidae: Sigmodontinae) with remarks on the phylogenetic

1431 relationships of O. gorgasi Hershkovitz, 1971. Caribbean Journal of Science 45:73-79

1432 DOI 10.18475/cjos.v45i1.a11.

1433 Voss RS, Gómez-Laverde M, Pacheco V. 2002. A new genus for Aepeomys fuscatus Allen,

1434 1912, and Oryzomys intectus Thomas, 1921: enigmatic murid rodents from Andean cloud

1435 forests. American Museum Novitates 3373:1-42.

1436 Weksler M. 2003. Phylogeny of Neotropical oryzomyine rodents (Muridae: Sigmodontinae)

1437 based on the nuclear IRBP exon. Molecular Phylogenetics and Evolution 29:331-349 DOI

$1438 \quad 10.1016 / \mathrm{S} 1055-7903(03) 00132-5$.

1439 Weksler M. 2006. Phylogenetic relationships of oryzomine rodents (Muroidea: Sigmodontinae):

1440 separate and combined analyses of morphological and molecular data. Bulletin of the

1441 American Museum of Natural History 296:1-149 DOI 10.1206/0003-

1442 0090(2006)296[0001:PROORM]2.0.CO;2.

1443 Weksler M. 2015. Tribe Oryzomyini Vorontsov, 1959. In: Patton JL, Pardiñas UFJ, D’Elía G,

1444 eds. Mammals of South America, Vol. 2: Rodents, 291-293.

1445 Weksler M, Percequillo AR, Voss RS. 2006. Ten new genera of oryzomyine rodents (Cricetidae:

1446 Sigmodontinae). American Museum Novitates 3537:1-29 DOI 10.1206/0003-

1447 0082(2006)3537[1:TNGOOR]2.0.CO;2. 
1448 Wible JR, Shelley SL. 2020. Anatomy of the petrosal and middle ear of the Brown Rat, Rattus

1449 norvegicus (Berkenhout, 1769) (Rodentia, Muridae). Annals of Carnegie Museum 86:1-35

$1450 \quad$ DOI $10.2992 / 007.086 .0101$.

1451 Wiens JJ. 1995. Polymorphic characters in phylogenetic systematics. Systematic Biology

1452 44:482-500 DOI 10.1093/sysbio/44.4.482.

1453 Williams SH, Kay RF. 2001. A comparative test of adaptive explanations for hypsodonty in

$1454 \quad$ ungulates and rodents. Journal of Mammalian Evolution 8:207-229.

1455 Xia, X. 2017. DAMBE6: New tools for microbial genomics, phylogenetics and molecular

1456 evolution. Journal of Heredity 108:431-437 DOI.org/10.1093/jhered/esx033

1457 Yánez-Muñoz M, Reyes-Puig C, Reyes-Puig J, Velasco J, Ayala-Varela F, Torres-Carvajal O.

1458 2018. A new cryptic species of Anolis lizard from northwestern South America (Iguanidae,

1459 Dactyloinae). ZooKeys 794:135-163 DOI 10.3897/zookeys.794.26936.

1460 Yang Z, Rannala B. 1997. Bayesian phylogenetic inference using DNA sequences: a Markov

1461 Chain Monte Carlo method. Molecular Biology and Evolution 14:717-724. 


\section{Table $\mathbf{1}$ (on next page)}

Uncorrected genetic distances ( $p$ distances).

Uncorrected genetic distances in percentages ( $p$-distances) between genera of clade B (sensu Weksler, 2006) of the Oryzomiynie tribe and among the three new species. The values on the diagonal represent the standard deviation. 
1

\begin{tabular}{|c|c|c|c|c|c|c|c|c|}
\hline \multicolumn{9}{|c|}{ Among Genus } \\
\hline & 1 & 2 & 3 & 4 & 5 & 6 & 7 & 8 \\
\hline 1 Euryoryzomys & & 0.86 & 0.76 & 0.88 & 0.79 & 0.77 & 0.91 & 0.83 \\
\hline 2 Handleyomys & 14.01 & & 0.67 & 0.81 & 0.75 & 0.72 & 0.91 & 0.70 \\
\hline 3 Hylaeamys & 13.34 & 14.58 & & 0.79 & 0.76 & 0.66 & 0.92 & 0.77 \\
\hline 4 Mindomys & 13.88 & 14.29 & 14.30 & & 0.75 & 0.81 & 1.02 & 0.87 \\
\hline 5 Nephelomys & 13.14 & 13.00 & 13.78 & 10.34 & & 0.71 & 0.82 & 0.72 \\
\hline 6 Oecomys & 12.65 & 14.04 & 13.64 & 13.66 & 12.90 & & 0.91 & 0.76 \\
\hline 7 Gen. nov. & 14.41 & 14.43 & 15.64 & 12.46 & 11.91 & 14.21 & & 1.00 \\
\hline 8 Transnadinomys & 12.75 & 14.94 & 14.68 & 15.04 & 13.70 & 13.95 & 14.99 & \\
\hline \multicolumn{9}{|c|}{ Within the new genus } \\
\hline & 1 & 2 & 3 & & & & & \\
\hline $\begin{array}{ll}1 \text { Reserva Drácula (sp.1) } \\
\text { Reserva Rio Manduriacu }\end{array}$ & & 0.87 & 0.83 & & & & & \\
\hline 2 (sp.2) & 7.87 & & 0.96 & & & & & \\
\hline 3 Reserva Otonga (sp.3) & 7.55 & 7.28 & & & & & & \\
\hline
\end{tabular}




\section{Table 2 (on next page)}

Morphological comparisons.

Morphological comparisons of selected traits among Pattonimus gen. nov. and other related oryzomyines. 


\begin{tabular}{|c|c|c|c|c|}
\hline & Pattonimus & Nephelomys ${ }^{1}$ & Mindomys $^{2}$ & Tanyuromys $^{3}$ \\
\hline $\begin{array}{l}\text { Dorsal hindfeet } \\
\text { condition }\end{array}$ & naked-looking & $\begin{array}{l}\text { scarcely covered } \\
\text { by short hairs }\end{array}$ & $\begin{array}{l}\text { densely covered } \\
\text { by short hairs }\end{array}$ & $\begin{array}{l}\text { scarcely covered by } \\
\text { short hairs }\end{array}$ \\
\hline & & long & mod & short \\
\hline atic notch & shal & well defined & ind & shallow \\
\hline rimal & smal & medium & med & small \\
\hline Interorbit & $\begin{array}{c}\text { anteriorly } \\
\text { convergent, with } \\
\text { sharp margins }\end{array}$ & $\begin{array}{l}\text { "hourglass," with } \\
\text { rounded margins }\end{array}$ & $\begin{array}{c}\text { anteriorly } \\
\text { convergent, with } \\
\text { beaded margins }\end{array}$ & $\begin{array}{l}\text { anteriorly convergent, } \\
\text { with sharp margins }\end{array}$ \\
\hline Antorbital bridge & broad & narrow & broad & narrow \\
\hline Molar & mediu & small & large & large \\
\hline $\begin{array}{l}\text { Incisive foramen } \\
\text { relative size }\end{array}$ & medium & small & medium & medium \\
\hline $\begin{array}{l}\text { Incisive foramen } \\
\text { maxillary septum }\end{array}$ & narrow & narrow & narrow & broad \\
\hline Palate & short & long & short & short \\
\hline $\begin{array}{l}\text { Postero } \\
\text { palatal }\end{array}$ & scarce & numerous & scarce & scarce \\
\hline Basioc & long & long & short & short \\
\hline $\begin{array}{l}\text { Zygomatic plate } \\
\text { upper border }\end{array}$ & not patent & patent & not patent & not patent \\
\hline Squamosal fenestra & smal & well-deve & abs & abse \\
\hline & scarcely ossified & scarc & scarcely ossified & well-ossified \\
\hline Alisphenoid strut & present & $\begin{array}{c}\text { unilaterally } \\
\text { present }\end{array}$ & absent & absent \\
\hline $\begin{array}{l}\text { Squamosal ridge } \\
\text { Sphenofrontal } \\
\text { foramen }\end{array}$ & $\begin{array}{l}\text { absent } \\
\text { covered by alar } \\
\text { fissure }\end{array}$ & $\begin{array}{l}\text { present } \\
\text { not covered by } \\
\text { alar fissure }\end{array}$ & $\begin{array}{l}\text { barely present } \\
\text { covered by alar } \\
\text { fissure }\end{array}$ & $\begin{array}{l}\text { present } \\
\text { absent }\end{array}$ \\
\hline Molar design & $\begin{array}{l}\text { incipiently } \\
\text { laminate }\end{array}$ & $\begin{array}{l}\text { not laminated, } \\
\text { bulbous }\end{array}$ & $\begin{array}{l}\text { not laminated, } \\
\text { bulbous }\end{array}$ & $\begin{array}{l}\text { not laminated, } \\
\text { bulbous }\end{array}$ \\
\hline $\begin{array}{l}\text { Enamel borders } \\
\text { lophs and lophids }\end{array}$ & straight & straight & straight & crenulate \\
\hline M1 procingulum & $\begin{array}{c}\text { compressed } \\
\text { without flexus }\end{array}$ & broad with flexus & $\begin{array}{l}\text { broad without } \\
\text { flexus }\end{array}$ & $\begin{array}{l}\text { broad with flexus and } \\
\text { fossete }\end{array}$ \\
\hline M1 & small c & & & \\
\hline M3 size & $\mathrm{M} 3<<\mathrm{M} 2$ & $\mathrm{M} 3<\mathrm{M} 2$ & $\mathrm{M} 3<\mathrm{M} 2$ & $\mathrm{M} 3<\mathrm{M} 2$ \\
\hline m3 shape & $\begin{array}{l}\text { subtriangular, } \\
\text { compressed }\end{array}$ & not compressed & not compressed & not compressed \\
\hline m1 procingulum & $\begin{array}{l}\text { compressed, } \\
\text { without flexid }\end{array}$ & broad, with flexid & $\begin{array}{l}\text { broad, with } \\
\text { fossetid }\end{array}$ & broad, with fossetid \\
\hline $\begin{array}{l}\text { m1 anterior murid } \\
\text { Mesolophids M1-M2 }\end{array}$ & $\begin{array}{l}\text { absent } \\
\text { absent }\end{array}$ & $\begin{array}{l}\text { present } \\
\text { present }\end{array}$ & & $\begin{array}{l}\text { present } \\
\text { present }\end{array}$ \\
\hline
\end{tabular}



Angular process
medium
medium
short and broad
short and broad

Number of ribs

12

12

?

12 or 13

$2{ }^{1}$ Character states are those of Nephelomys albigularis; other species currently classified under the genus

3 may possess different attributes. ${ }^{2}$ Character states are those of Mindomys hammondi. ${ }^{3}$ Character states

4 are those of Tanyuromys thomasleei; other species currently classified under the genus may possess

5 different attributes. 


\section{Table 3(on next page)}

Individual external craniodental measurements (in mm).

Individual external craniodental measurements (in $\mathrm{mm}$, except body mass) of the paratypes of Pattonimus ecominga sp. nov. and Pattonimus musseri sp. nov. and the material referred as Pattonimus sp. (Oryzomyini, Sigmodontinae). 
1

\begin{tabular}{|c|c|c|c|c|c|c|c|c|c|c|c|c|c|c|c|}
\hline \multirow{3}{*}{$\begin{array}{l}\text { Collectio } \\
\mathrm{n}\end{array}$} & \multicolumn{10}{|c|}{ P. ecominga sp. nov. } & \multicolumn{3}{|c|}{ P. musseri sp. nov. } & \multicolumn{2}{|c|}{ Pattonimus sp } \\
\hline & MEC & MEC & MEC & MEC & MEC & MEC & MEC & MEC & MEC & MEC & MEP & MEP & MEP & & \\
\hline & $\mathrm{N}$ & $\mathrm{N}$ & $\mathrm{N}$ & $\mathrm{N}$ & $\mathrm{N}$ & $\mathrm{N}$ & $\mathrm{N}$ & $\mathrm{N}$ & $\mathrm{N}$ & $\mathrm{N}$ & $\mathrm{N}$ & $\mathrm{N}$ & $\mathrm{N}$ & ICN & ICN \\
\hline Number & 5927 & 6017 & 6019 & 6020 & 6025 & 6040 & 6041 & 6042 & 6043 & 6173 & 12586 & 12587 & 12593 & 13663 & 21487 \\
\hline Sex & $\mathrm{F}$ & M & M & $\mathrm{F}$ & M & $\mathrm{F}$ & M & M & $\mathrm{F}$ & $\mathrm{F}$ & $\mathrm{F}$ & $\mathrm{M}$ & M & M & $\mathrm{F}$ \\
\hline Age & 3 & 1 & 3 & 3 & 4 & 3 & 3 & 3 & 3 & 3 & 3 & 5 & 0 & 3 & 4 \\
\hline $\mathrm{HB}$ & 138.00 & 103.00 & 120.00 & 110.00 & 130.00 & 120 & 117 & 118 & 120 & 115 & 115 & 130 & 95 & $\begin{array}{c}136.0 \\
0 \\
184.0\end{array}$ & $\begin{array}{c}140.0 \\
0 \\
180.0\end{array}$ \\
\hline TL & 188.00 & 135.00 & 170.00 & 171.00 & 180 & 171 & 155 & 160 & 155 & 156 & 139 & 190 & 120 & 0 & 0 \\
\hline $\mathrm{HF}$ & 33.00 & 33.00 & 33.00 & 31.00 & 34 & 35 & 35 & 33 & 33 & 34 & 32 & 35 & 28 & 36.00 & 35.20 \\
\hline $\mathrm{E}$ & 19.00 & 15.00 & 18.00 & 14.00 & 16 & 16 & 16 & 16 & 15 & 16 & 17 & 19 & 17 & 20.00 & 15.50 \\
\hline LMV & 50.23 & 53.00 & 53.00 & 56.00 & 60 & 54 & 52.1 & 55 & 50.94 & 51 & 51.22 & 60.3 & 33.4 & - & - \\
\hline LSV & 30.00 & 25.00 & 29.00 & 27.00 & 31 & 28 & 19.64 & 26 & 27.65 & 25 & 17.59 & 29.05 & 21.47 & - & - \\
\hline LGV & 25.00 & 18.00 & 19.00 & 23.00 & 21 & 22 & - & 18 & 20.7 & 20 & 19.45 & 16.58 & 17.23 & - & - \\
\hline W & 64.00 & 30.00 & 57.00 & 60.00 & 83 & 76 & 64 & 55 & 54 & 47 & 44.5 & 110 & 25 & 72.00 & 68.00 \\
\hline ONL & 33.67 & - & 32.29 & 31.16 & 34.6 & 32.94 & - & 32.27 & 31.43 & 30.38 & 29.61 & 36.73 & 26.21 & - & - \\
\hline CIL & 31.22 & 24.66 & 29.98 & 29.27 & 32.1 & 30.48 & 29.44 & 30.03 & 28.73 & 28.36 & 26.85 & 33.75 & 24.53 & 31.63 & 31.33 \\
\hline LD & 8.43 & 6.48 & 8.40 & 8.04 & 8.94 & 8.02 & 7.92 & 8.20 & 8.14 & 7.50 & 7.18 & 9.67 & 6.35 & 9.37 & 8.88 \\
\hline LUM & 5.71 & 5.35 & 5.50 & 5.56 & 5.41 & 5.61 & 5.72 & 5.60 & 5.50 & 5.53 & 5.56 & 5.83 & - & 5.50 & 5.60 \\
\hline LIF & 4.06 & 3.43 & 4.33 & 4.3 & 4.96 & 4.45 & 4.71 & 4.53 & 4.46 & 4.03 & 3.5 & 4.47 & 3.48 & 4.94 & 5.43 \\
\hline BIF & 1.75 & 1.66 & 1.73 & 1.84 & 1.7 & 1.71 & 1.93 & 1.74 & 1.92 & 1.56 & 1.47 & 1.84 & 1.58 & 1.96 & 2.25 \\
\hline BM1 & 1.79 & 1.67 & 1.79 & 1.75 & 1.77 & 1.74 & 1.8 & 1.73 & 1.68 & 1.73 & 1.80 & 1.80 & 1.70 & 1.74 & 1.77 \\
\hline BR & 6.70 & 5.13 & 6.22 & 6.01 & 6.27 & 5.98 & 5.89 & 5.90 & 5.87 & 5.86 & 5.30 & 6.80 & 5.22 & 5.70 & 5.47 \\
\hline LN & 13.02 & - & 12.62 & 12.16 & 13.08 & 12.06 & 11.74 & 11.45 & 11.55 & 11.07 & 10.63 & 13.32 & 9.24 & 13.2 & 13.74 \\
\hline LPB & 7.53 & 6.09 & 7.26 & 6.98 & 7.75 & 7.15 & 6.60 & 6.92 & 6.27 & 6.77 & 6.92 & 8.05 & 5.49 & 7.36 & 7.02 \\
\hline BBP & 2.71 & 2.22 & 2.78 & 2.64 & 2.22 & 2.63 & 2.60 & 2.74 & 2.73 & 2.54 & 2.21 & 2.63 & 2.08 & - & 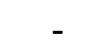 \\
\hline LIB & 5.79 & 5.58 & 6.04 & 5.76 & 5.72 & 5.9 & 5.83 & 5.62 & 5.77 & 5.86 & 5.56 & 5.73 & 5.56 & 6.09 & 5.76 \\
\hline ZB & 16.76 & 14.40 & 16.55 & 16.22 & 17.61 & 16.57 & 16.40 & 16.38 & 15.80 & 15.96 & 14.8 & 17.1 & 14.53 & 17.67 & 17.37 \\
\hline BZP & 3.41 & 2.97 & 3.62 & 3.43 & 4.02 & 3.45 & 3.33 & 3.48 & 3.28 & 3.46 & 3.35 & 4.20 & 2.62 & 4.01 & 3.97 \\
\hline LB & 13.33 & 12.40 & 13.14 & 12.57 & 12.95 & 12.68 & 12.85 & 13.08 & 12.89 & 12.6 & 12.22 & 13.77 & 12.12 & - & - \\
\hline OFL & 10.34 & 8.86 & 10.08 & 9.90 & 11.1 & 10.54 & 10.39 & 10.53 & 9.94 & 9.69 & 9.57 & 11.20 & 8.76 & 11.03 & 10.93 \\
\hline BB & 3.80 & - & 3.83 & - & 3.82 & 3.82 & 3.75 & 3.82 & 3.70 & 3.88 & 3.65 & 3.81 & 3.53 & - & - \\
\hline LM & 17.91 & 15.30 & 17.54 & 16.63 & 17.90 & 17.38 & 16.68 & 16.81 & 16.73 & 16.73 & 15.16 & 18.98 & 14.82 & - & - \\
\hline LLM & 5.51 & 5.46 & 5.50 & 5.68 & 5.46 & 5.52 & 5.63 & 5.53 & 5.49 & 5.61 & 5.49 & 5.64 & - & - & - \\
\hline
\end{tabular}




\section{Table 4 (on next page)}

Individual molar measurements (in $\mathrm{mm}$ ).

Individual molar measurements (in $\mathrm{mm}$ ) of the type series of Pattonimus ecominga sp. nov. and Pattonimus musseri sp. nov. (Oryzomyini, Sigmodontinae). * = Holotypes. 


\begin{tabular}{|c|c|c|c|c|c|c|c|c|c|c|c|c|c|c|c|}
\hline & \multicolumn{11}{|c|}{ P. ecominga sp. nov. } & \multicolumn{4}{|c|}{ P. musseri sp. nov. } \\
\hline Collection & MECN & MECN & MECN & MECN & MECN & MECN & MECN & MECN & MECN & MECN & MENC & MEPN & MEPN & MEPN & MEPN \\
\hline Number & 5927 & $5928^{*}$ & 6017 & 6019 & 6020 & 6025 & 6040 & 6041 & 6042 & 6043 & 6173 & 12586 & 12587 & 12593 & $12605^{*}$ \\
\hline Age & 3 & 3 & 1 & 3 & 3 & 4 & 3 & 3 & 3 & 3 & 3 & 3 & 5 & 0 & 4 \\
\hline Length M1 & 2.54 & 2.72 & 2.61 & 2.80 & 2.79 & 2.64 & 2.86 & 2.78 & 2.79 & 2.50 & 2.87 & 2.47 & 2.74 & 2.68 & 2.65 \\
\hline Width M1 & 1.73 & 1.77 & 1.80 & 1.77 & 1.73 & 1.74 & 1.79 & 1.75 & 1.74 & 1.67 & 1.79 & 1.68 & 1.80 & 1.73 & 1.70 \\
\hline Length M2 & 1.51 & 1.75 & 1.74 & 1.56 & 1.46 & 1.45 & 1.62 & 1.52 & 1.60 & 1.75 & 1.59 & 1.31 & 1.58 & 1.76 & 1.48 \\
\hline Width M2 & 1.75 & 1.78 & 1.64 & 1.84 & 1.68 & 1.68 & 1.78 & 1.73 & 1.65 & 1.70 & 1.73 & 1.77 & 1.88 & 1.80 & 1.75 \\
\hline Length M3 & 1.30 & 1.24 & - & 1.17 & 1.23 & 1.15 & 1.10 & 1.35 & 1.35 & 1.13 & 1.25 & 1.23 & 1.39 & - & 1.25 \\
\hline Width M3 & 1.37 & 1.35 & - & 1.36 & 1.33 & 1.32 & 1.30 & 1.30 & 1.32 & 1.33 & 1.32 & 1.34 & 1.42 & - & 1.41 \\
\hline Length $\mathrm{m} 1$ & 2.25 & 2.28 & 2.16 & 2.38 & 2.41 & 2.35 & 2.10 & 2.30 & 2.26 & 2.21 & 2.33 & 2.16 & 2.28 & 2.23 & 1.94 \\
\hline Width m1 & 1.66 & 1.66 & 1.60 & 1.68 & 1.69 & 1.74 & 1.57 & 1.74 & 1.60 & 1.57 & 1.66 & 1.66 & 1.70 & 1.70 & 1.50 \\
\hline Length $\mathrm{m} 2$ & 1.71 & 1.72 & 1.77 & 1.76 & 1.76 & 1.66 & 1.75 & 1.68 & 1.70 & 1.73 & 1.74 & 1.56 & 1.80 & 1.76 & 1.76 \\
\hline Width m2 & 1.76 & 1.68 & 1.67 & 1.76 & 1.67 & 1.71 & 1.70 & 1.73 & 1.66 & 1.55 & 1.73 & 1.68 & 1.81 & 1.78 & 1.67 \\
\hline Length $\mathrm{m} 3$ & 1.55 & 1.47 & - & 1.54 & 1.65 & 1.61 & 1.56 & 1.65 & 1.62 & 1.41 & 1.52 & 1.62 & 1.70 & - & 1.43 \\
\hline Width m3 & 1.45 & 1.34 & - & 1.46 & 1.35 & 1.34 & 1.34 & 1.36 & 1.36 & 1.30 & 1.37 & 1.35 & 1.44 & - & 1.38 \\
\hline
\end{tabular}

3 


\section{Figure 1}

Phylogenetic relationships of the tribe Oryzomyini.

Phylogenetic relationships of the tribe Oryzomyini. Tree obtained from IB of DNA sequences of mitochondrial (Cytb 800 to 1,143 bp), and nuclear (IRBP 700 to 1,266 bp) genes and 103 morphological characters, from 63 terminals. Numbers below branches are ML bootstrap support and posterior probability values. Letters ( $A$ to $D$ ) indicate clades. The dash line indicated the position of new taxa. 


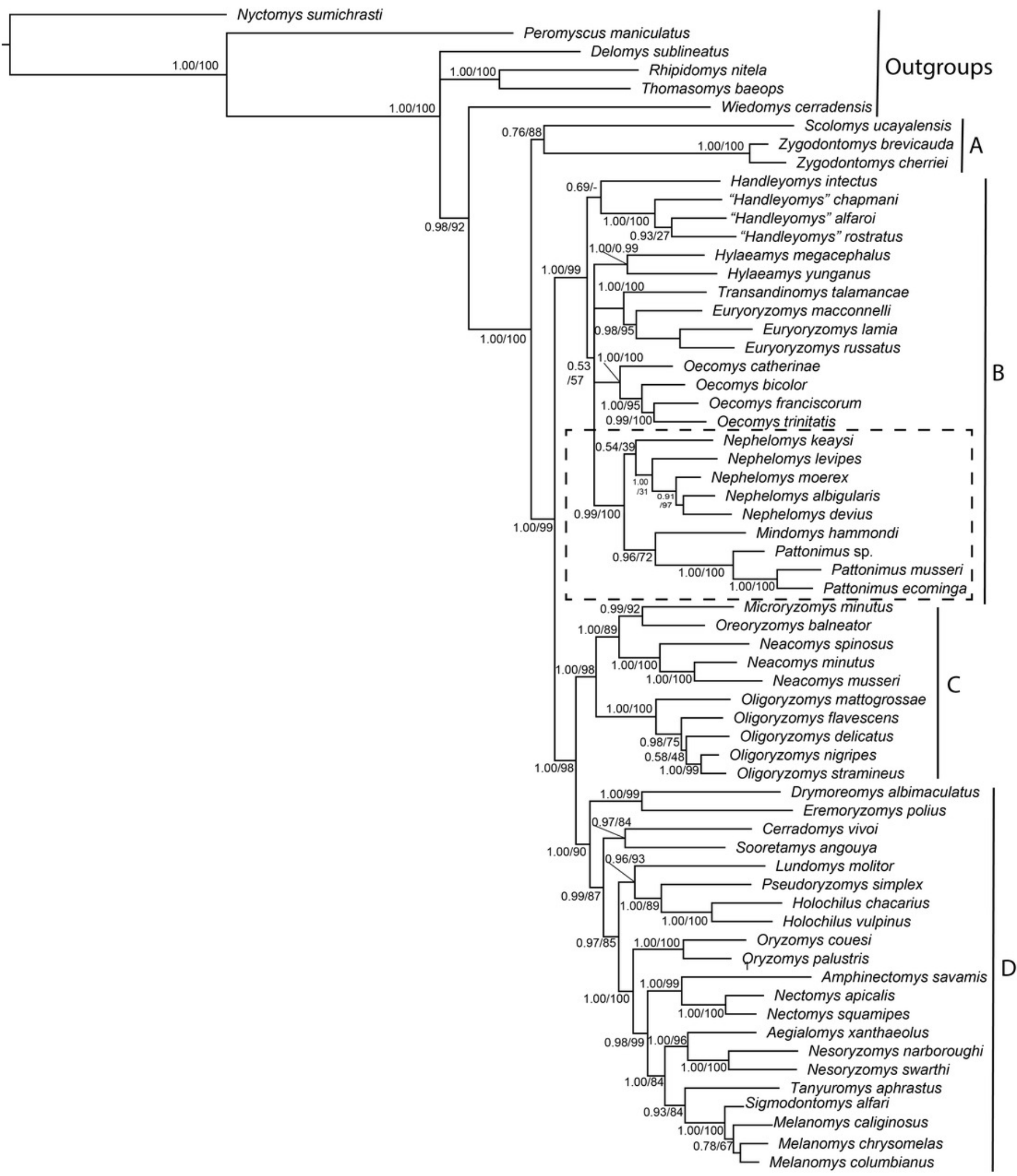


Figure 2

Phylogenetic relationships of the tribe Oryzomyini.

Phylogenetic relationships of the tribe Oryzomyini. Tree obtained from IB analysis of DNA sequences concatenated Cytb + IRPB genes of up to 2,049 bp. Numbers below branches are bootstrap support and posterior probability values. The dash line indicated the position of new taxa. 


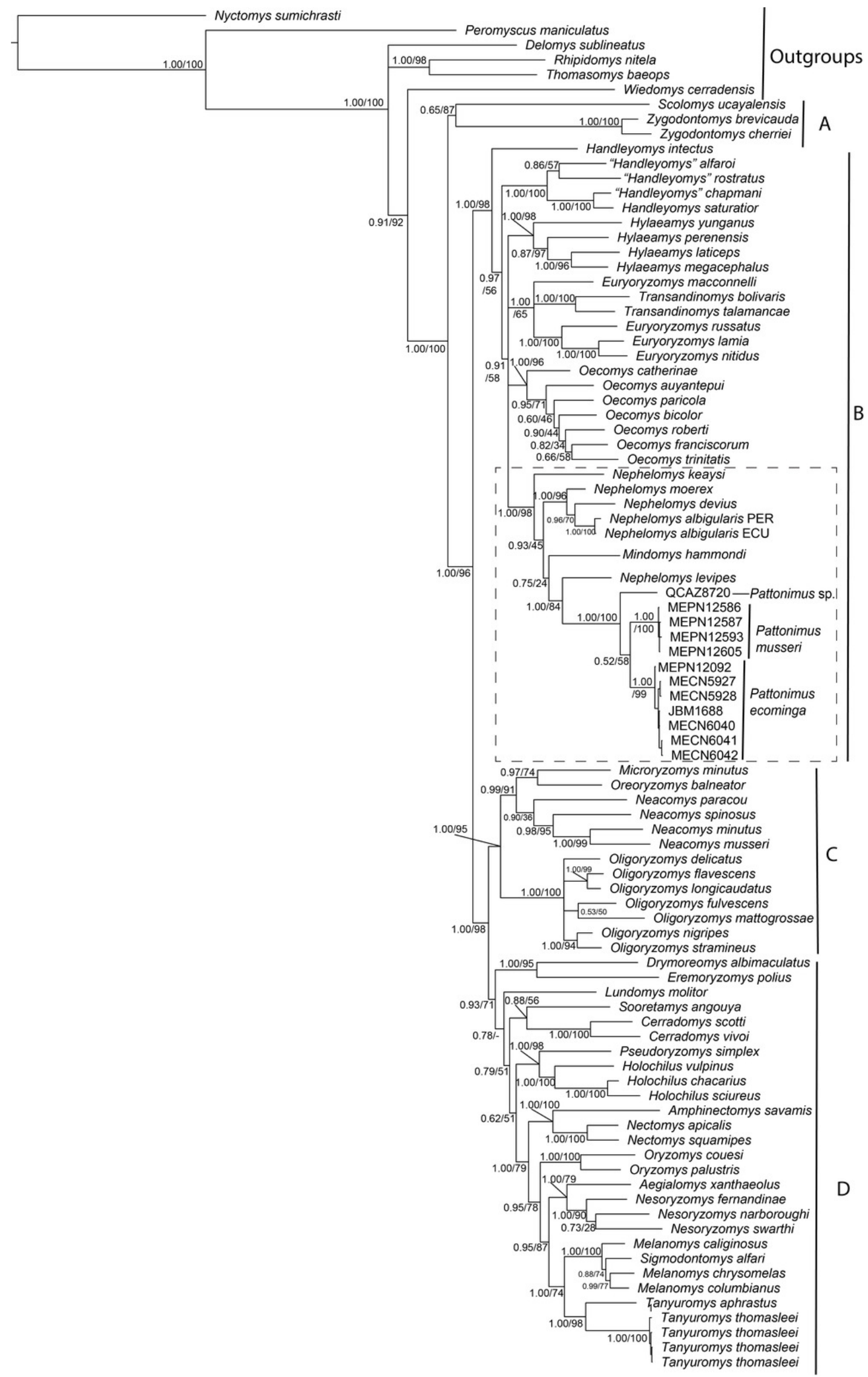




\section{Figure 3}

Selected aspects of qualitative anatomy contrasted.

Selected aspects of qualitative anatomy contrasted in the crania of Pattonimus gen. nov. (left half, A-D; MECN 5928, holotype of Pattonimus ecominga sp. nov., genotype) vs. Mindomys hammondi (right half, A, C; BM 13.10.24.58, holotype) and Nephelomys auriventer (right half, B, D; MECN 5812), scaled to the same length. The figure portrays contrasts between several characteristics highlighted by pointers.

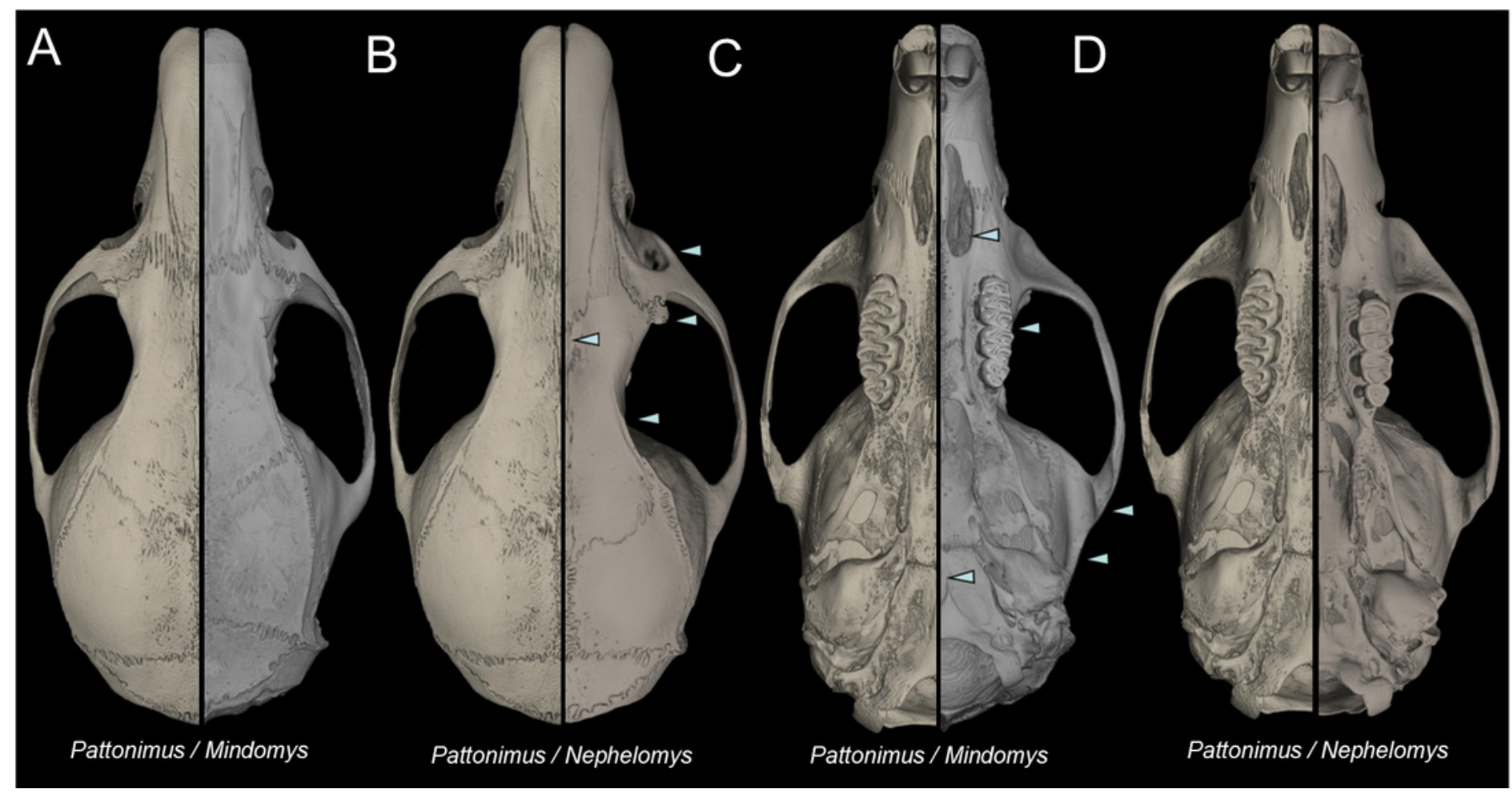




\section{Figure 4}

Comparison of selected anatomical regions of the cranium.

Comparison of selected anatomical regions of the cranium of Pattonimus gen. nov. (A, E, I; MECN 5928, holotype of Pattonimus ecominga sp. nov., genotype), Mindomys hammondi (B, F, J; BMNH 13.10.24.58, holotype), Nephelomys auriventer (C, G, K; MECN 5812) and Tanyuromys thomasleei (D, H, L; MECN 3407). Right squamosal-alisphenoid region in lateral view (left), right auditory region in lateral view (middle) and right auditory capsule in ventral view (right). Abbreviations: aalc $=$ anterior opening of alisphenoid canal; $a c=$ anterior crus of ectotympanic; al = alisphenoid; als = alisphenoid strut; bet = bony eustachian tube; bo = basioccipital; $c c=$ carotid canal; cty = crista tympanica; $\mathrm{e}=$ ectotympanic; fo $=$ foramen ovale; $\mathrm{mbt}=$ trough for masticatory-buccinator nerve; $\mathrm{me}=$ mastoid exposure; $\mathrm{mlf}=$ middle lacerate foramen; $\mathrm{pgf}=$ postglenoid foramen; $\mathrm{pp}=$ paroccipital process of petrosal; $\mathrm{pt}=$ petrosal; sact $=$ tunnel for secondary arterial connection between internal carotid and orbitalmaxillary circulation; sag = squamosal alisphenoid groove; sfr = sphenofrontal foramen; smf = stylomastoid foramen; $\mathrm{sq}$ = squamosal; $\mathrm{stf}=$ stapedial foramen; sts = stapedial process of bulla (rostral process of malleus?); $\mathrm{tt}=$ tegmen tympani. 


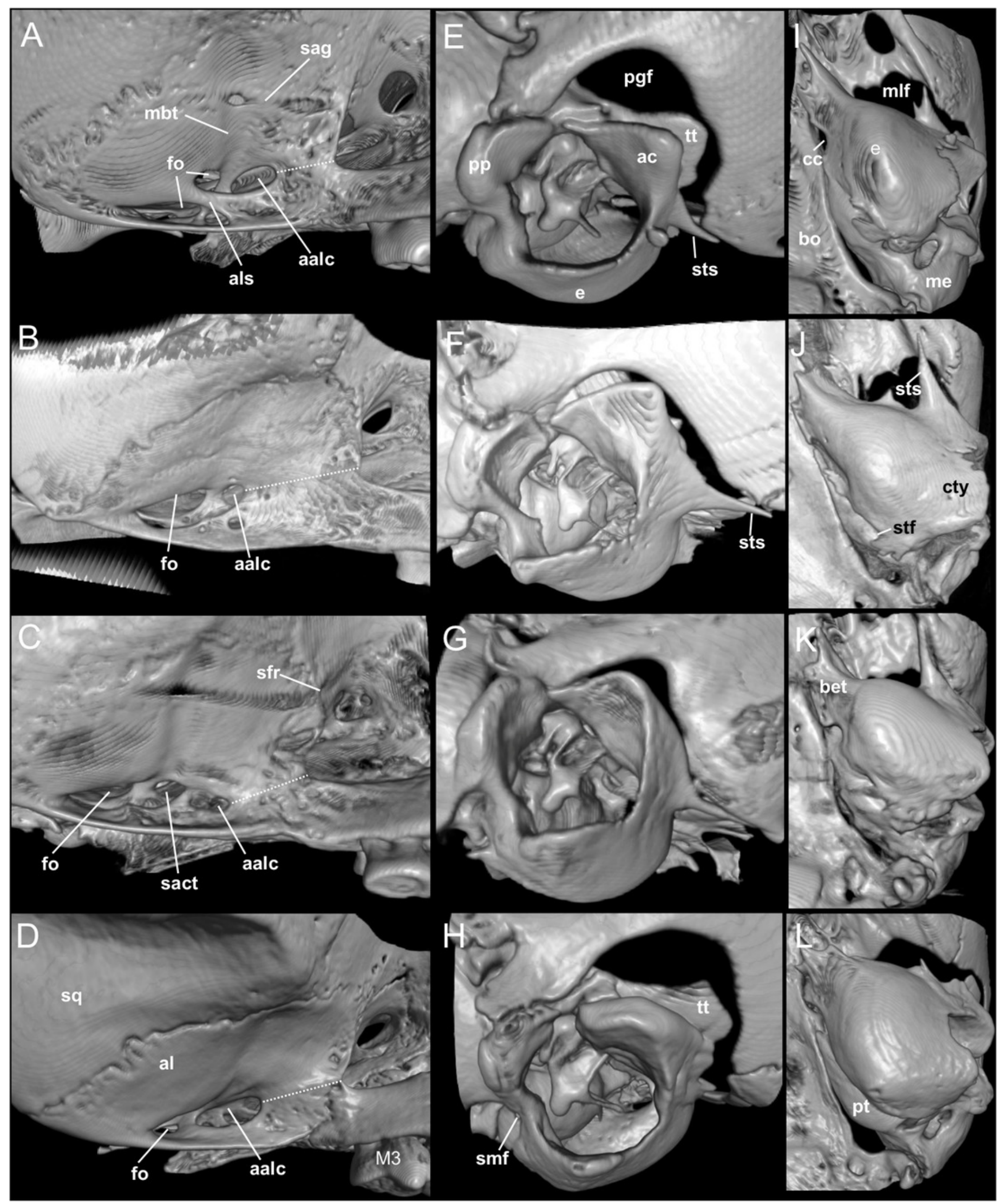




\section{Figure 5}

Lower right toothrows in occlusal view.

A, B, C, Upper and D, E, F, lower right toothrows in occlusal view of Pattonimus gen. nov. (A,

D; MECN 5928, holotype of Pattonimus ecominga sp. nov., genotype), Mindomys hammondi

(B, E; BMNH 13.10.24.58, holotype) and Nephelomys albigularis (C, F; MECN 583).

Abbreviations: an = anteroloph; am = anterior murid; $\mathrm{fa}=$ anteromedian flexus; $\mathrm{m}=$ mesoloph/id; $p=$ procingulum. Scale $=1 \mathrm{~mm}$.

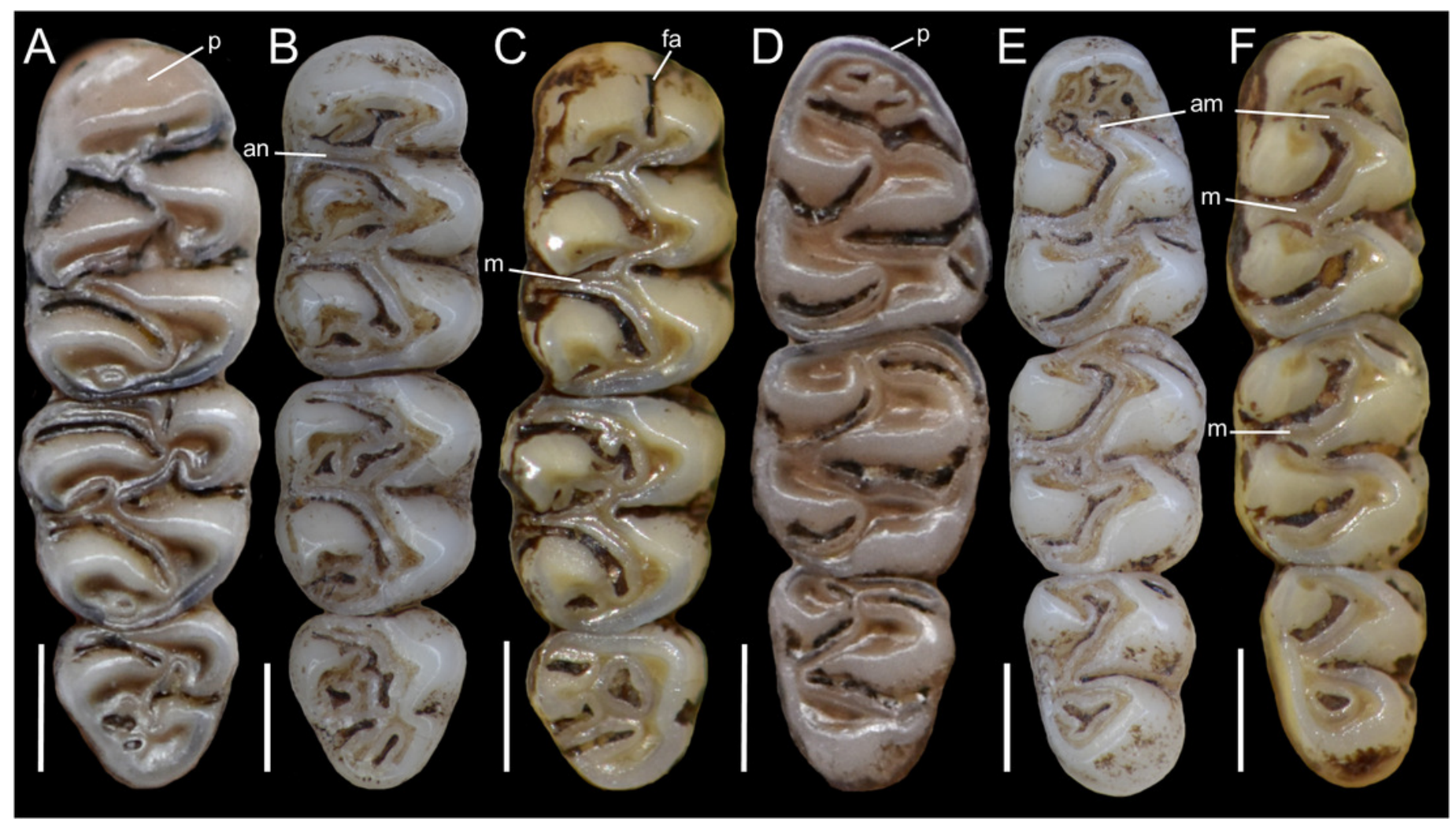


Figure 6

Pattonimus gen. nov., geographic distribution in Ecuador and Colombia.

Pattonimus gen. nov. (Oryzomyini, Sigmodontinae), geographic distribution in Ecuador and

Colombia. The white triangle represent the type locality.

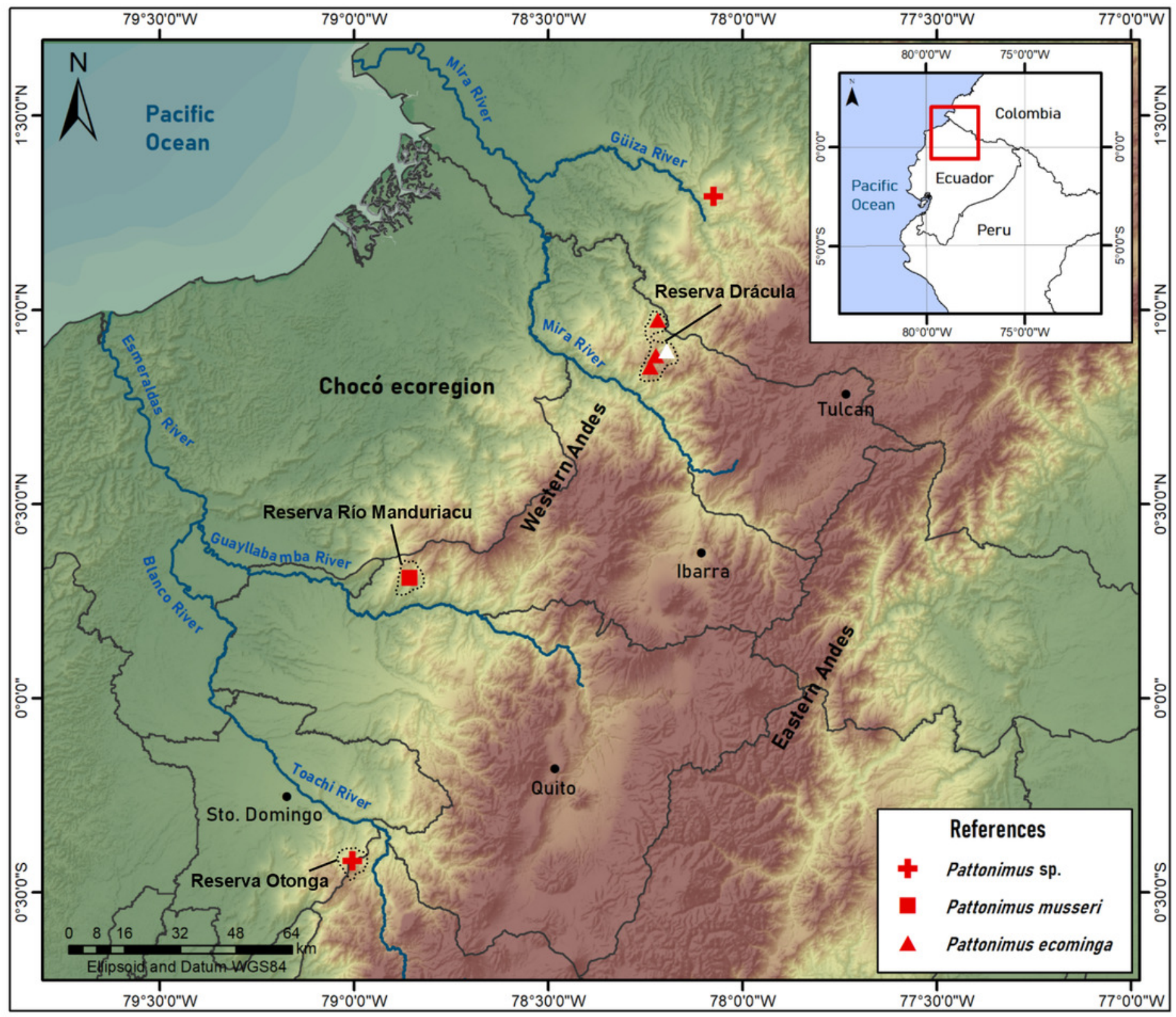


Figure 7

Principal component analysis

Scatter plot (A, B) of principal component analysis (PCA) of Pattonimus gen. nov. 

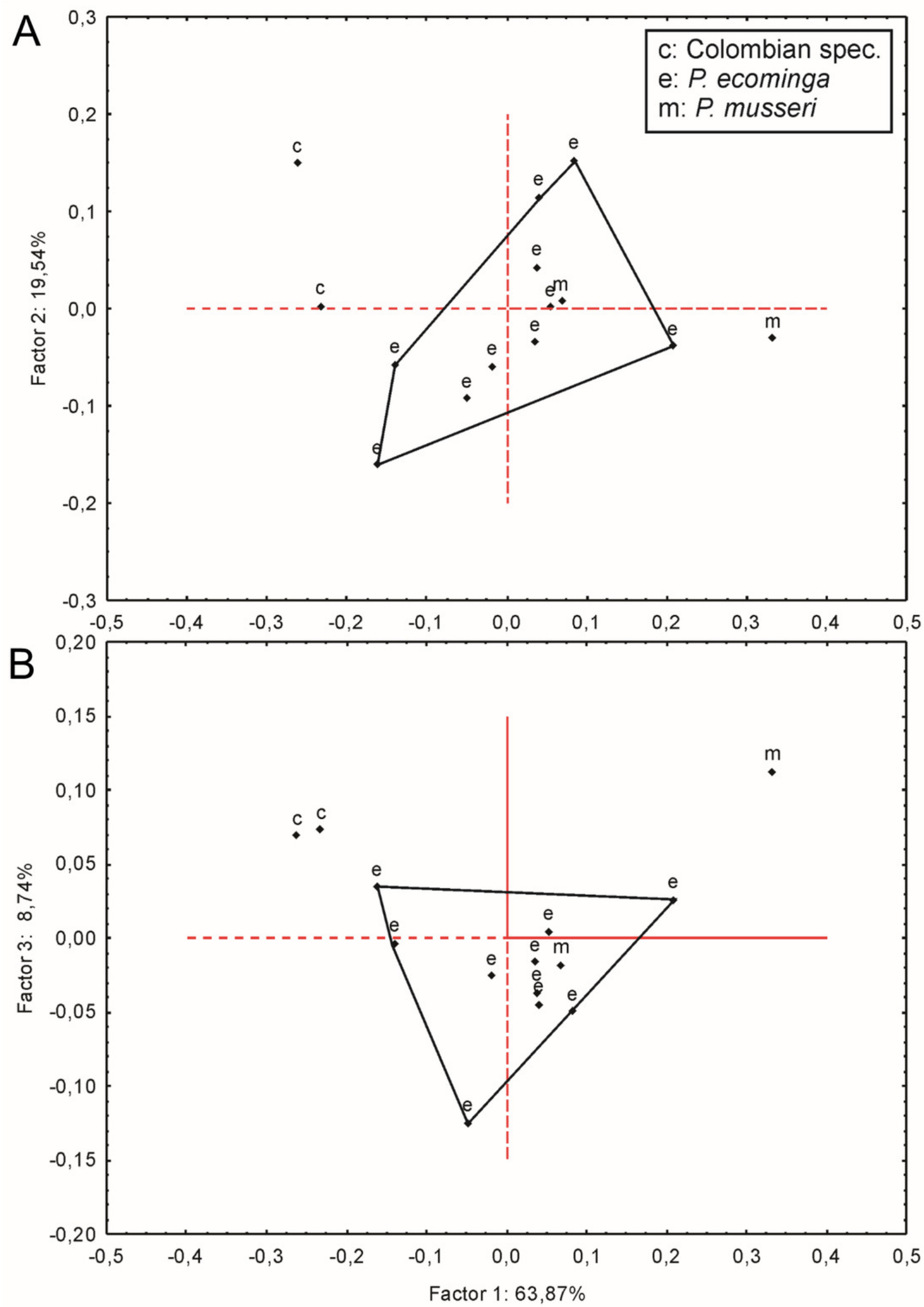


\section{Figure 8}

Pattonimus gen. nov. (Oryzomyini, Sigmodontinae), selected features of external and internal anatomy.

Pattonimus gen. nov. (Oryzomyini, Sigmodontinae), selected features of external and internal anatomy (based on MECN 5928, holotype of $P$. ecominga sp. nov., genotype): $A$, dorsal and B, plantar surface of the right manus; $C$, dorsal and $D$, plantar surface of the right pes; $E$, right ear, internal view; $F$, rhinarium, ventral view; $G, H$, stomach, mid-dorsal portions in external and internal view, respectively; I, tail, anterior portion in dorsal view. Abbreviations: 1-5 = digits; $a=$ antrum; at $=$ antitragus; $b f=$ bordering fold; $c e=$ cornified epithelium; $c i=$ crus inferius of the narial pad; $c o=$ concha; $d=$ duodenum; $e=$ esophagus; ge = glandular epithelium; he = helix; $i=$ incisive; $i a=$ incisura angularis; $n=$ nostrils; $n p=$ nasal pads; $p h$ $=$ philtrum. 

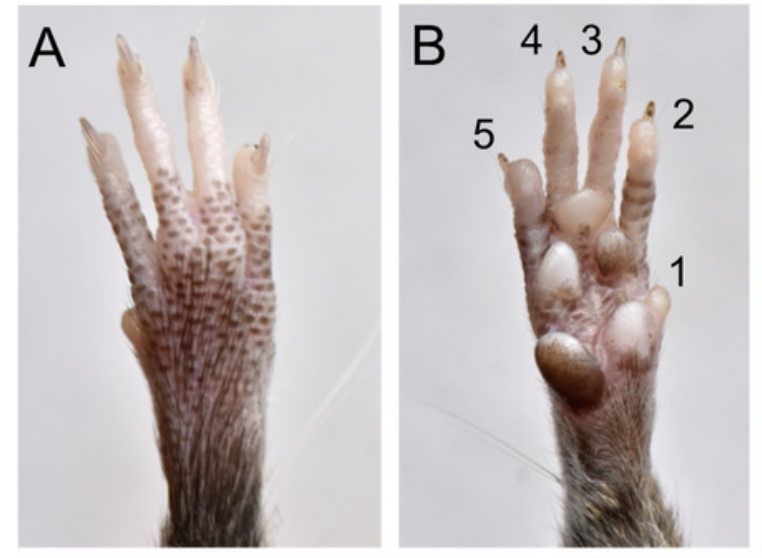

C
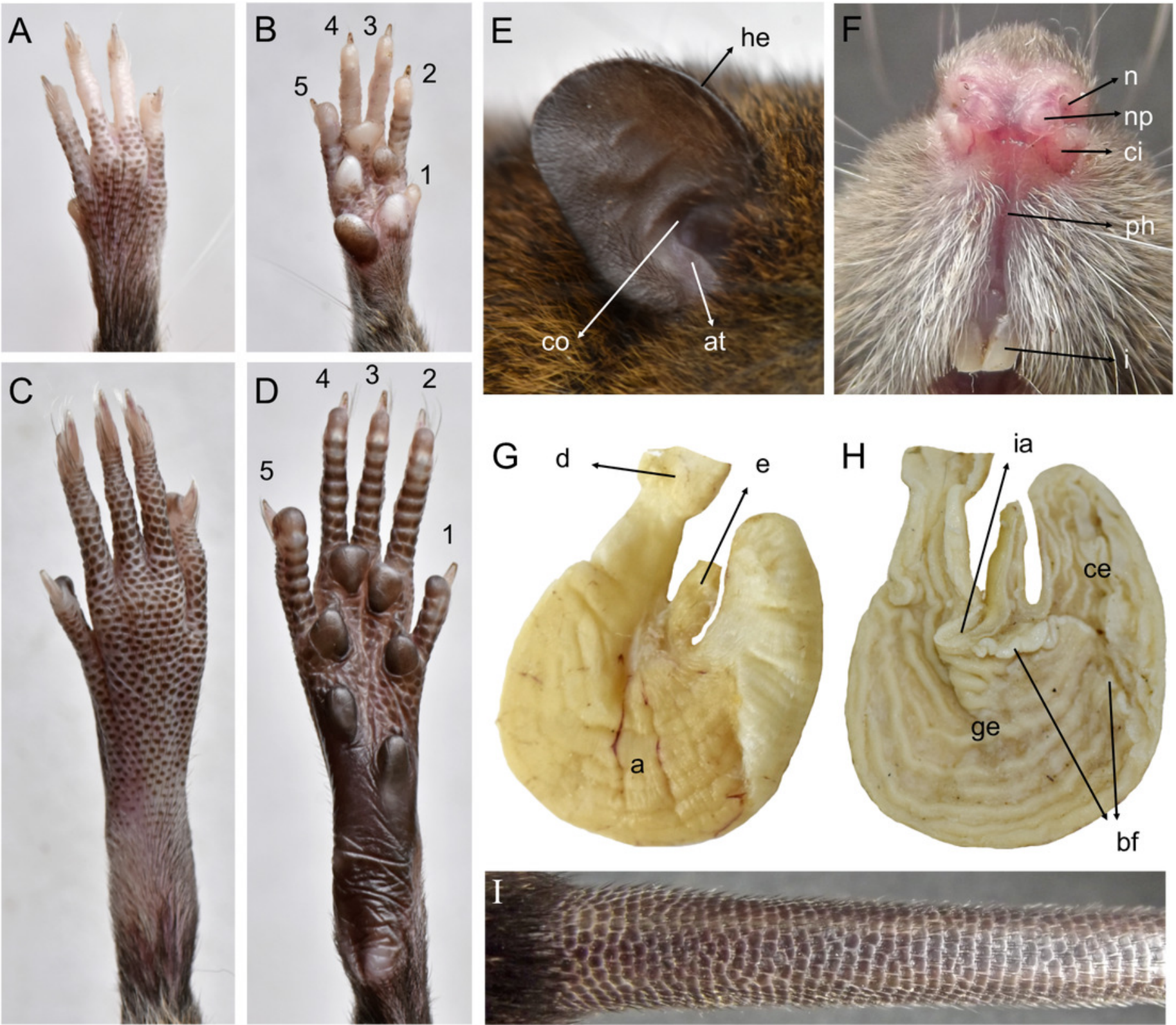


\section{Figure 9}

Pattonimus ecominga sp. nov.

Pattonimus ecominga sp. nov. (MECN 5928, holotype), an adult male from Reserva Drácula, Carchi, Ecuador.

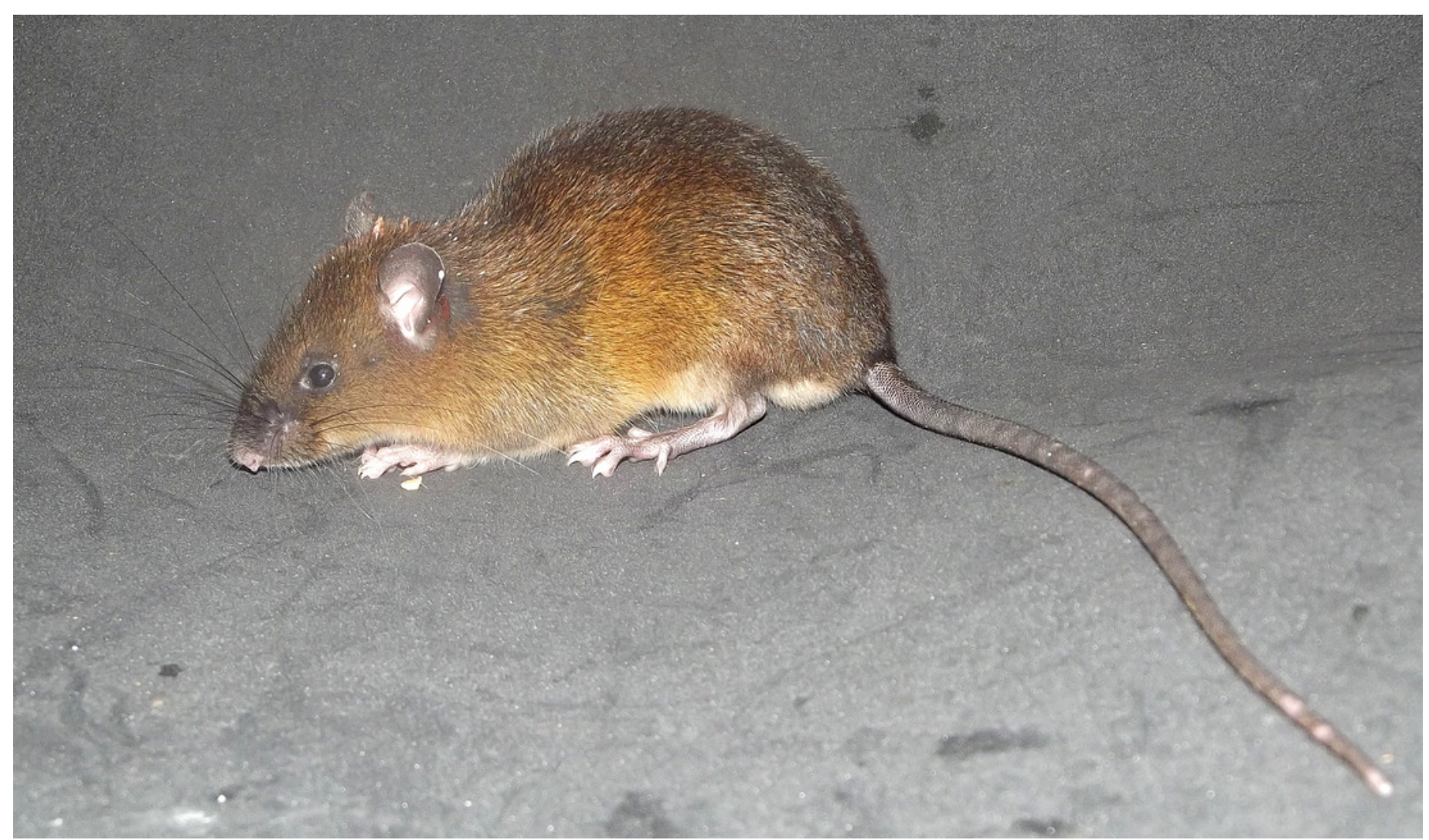




\section{Figure 10}

Cranium in dorsal, ventral, and lateral views, and mandible in labial view

Pattonimus ecominga sp. nov. (Reserva Drácula, Carchi, Ecuador): A, cranium in dorsal, B, ventral, C, lateral views, and D, mandible in labial view (MECN 5928, holotype). Scale $=10$ $\mathrm{mm}$. 


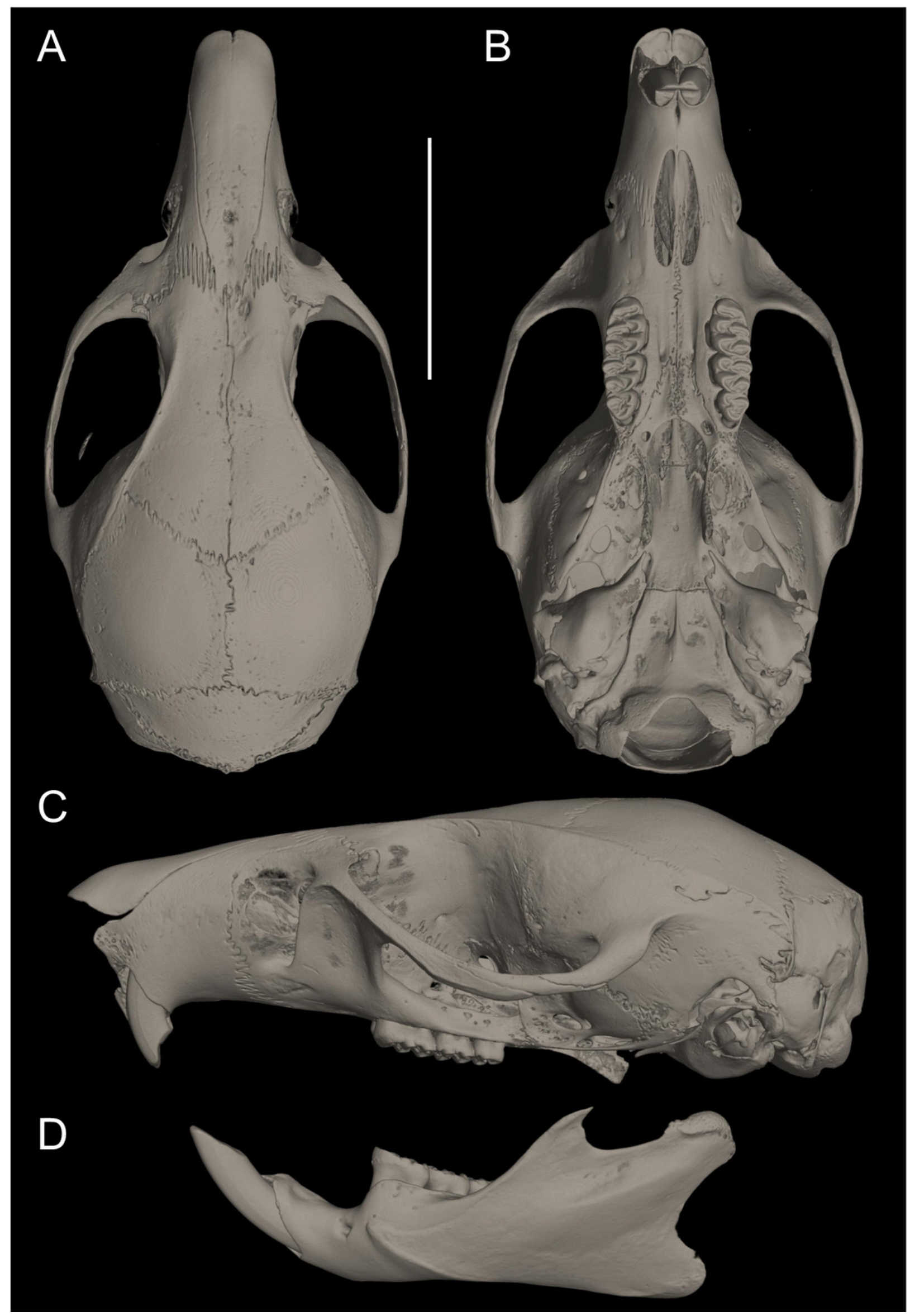

PeerJ reviewing PDF | (2020:06:50405:2:0:NEW 28 Sep 2020) 


\section{Figure 11}

Main cranial traits differentiating species of Pattonimus gen. nov.: Pattonimus ecominga sp. nov. (top; MECN 5928, holotype) vs. Pattonimus musseri sp. nov.

Main cranial traits differentiating species of Pattonimus gen. nov.: Pattonimus ecominga sp. nov. (A, C, E; MECN 5928, holotype) vs. Pattonimus musseri sp. nov. (B, D, F; MEPN 12605, holotype). A, B, zygomatic notch region in dorsal view; $C, D$, right posterior part of the cranium in lateral view; and E, F, right orbital region in lateral view (zygomatic arch removed). Abbreviations: $a b=$ antorbital bridge; $a f=$ alar fissure (with a basal notch); $I=$ lacrimal; $p=$ parietal (lateral expression); ssf = subsquamosal fenestra.

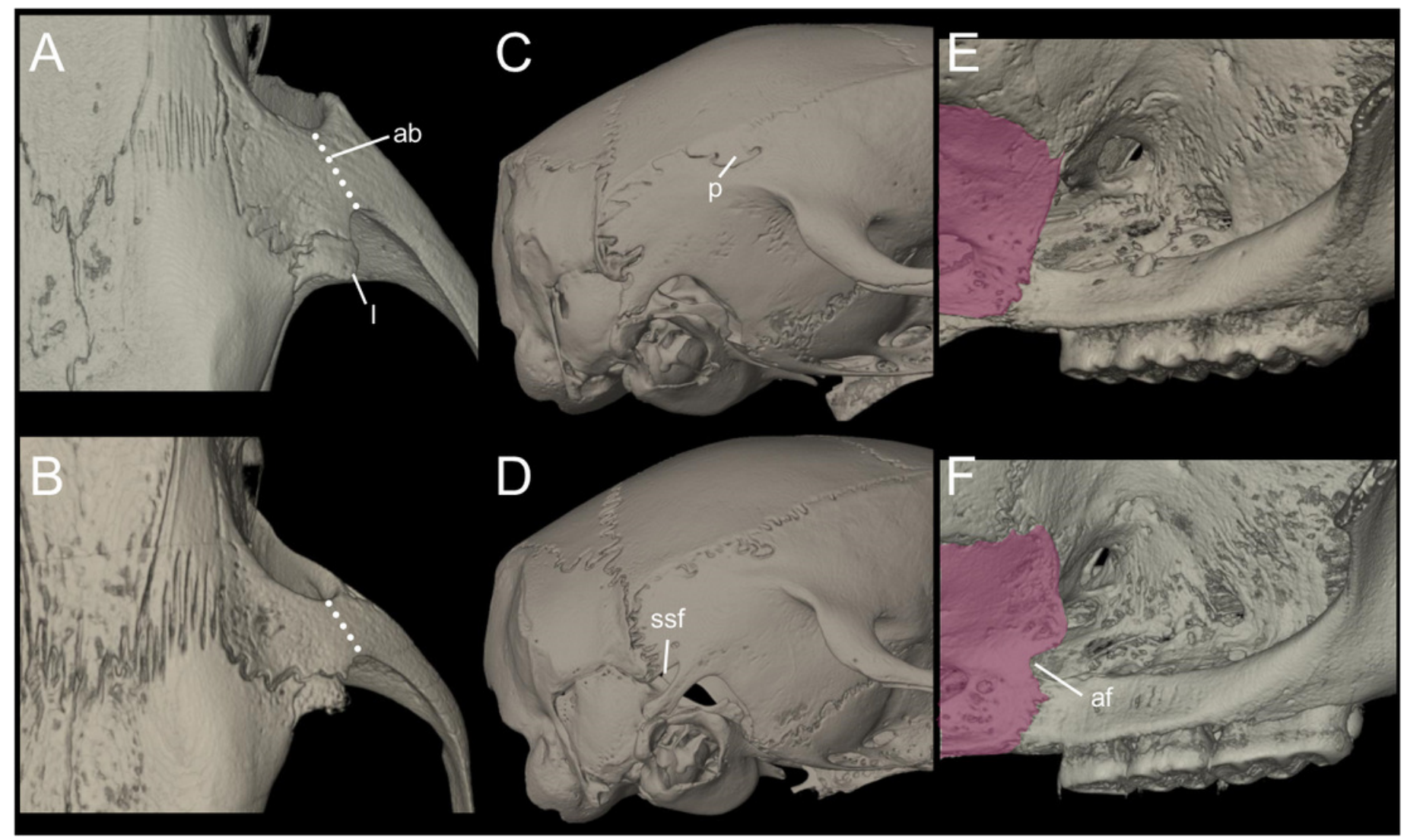




\section{Figure 12}

Upper and lower right toothrows

A, B, Upper and C, D, lower right toothrows in occlusal view of Pattonimus ecominga sp. nov. (A, C; Reserva Drácula, Carchi, Ecuador; MECN 5928, holotype) and Pattonimus musseri sp. nov. (B, D; Reserva Río Manduriacu, Imbabura, Ecuador; MEPN 12605, holotype). Scale = 1 $\mathrm{mm}$.

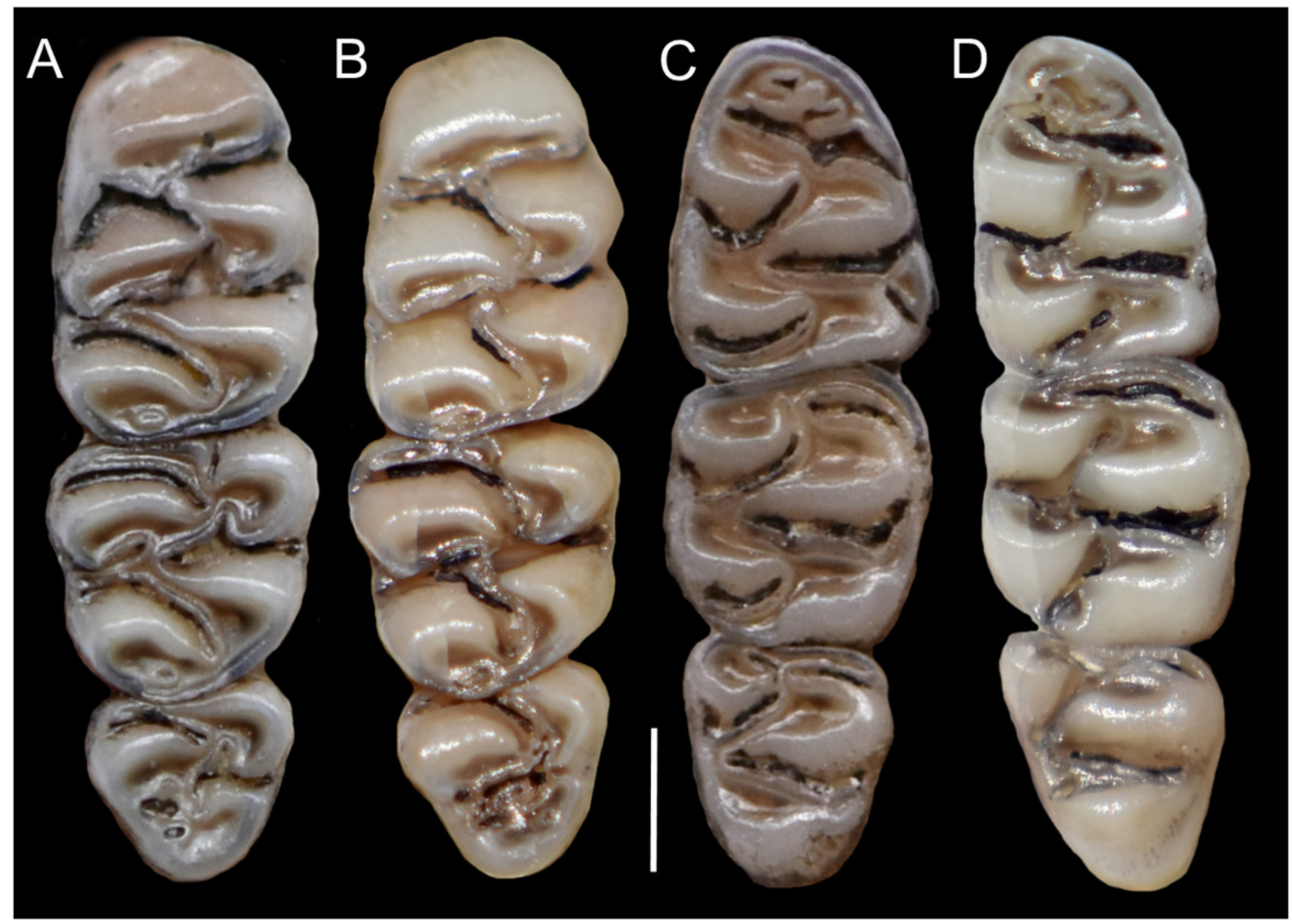




\section{Figure 13}

Pattonimus musseri sp. nov.

Pattonimus musseri sp. nov. (Reserva Río Manduriacu, Imbabura, Ecuador): A, cranium in dorsal, B, ventral, C, lateral view, and D, mandible in labial views (MEPN 12605, holotype). Scale $=10 \mathrm{~mm}$. 


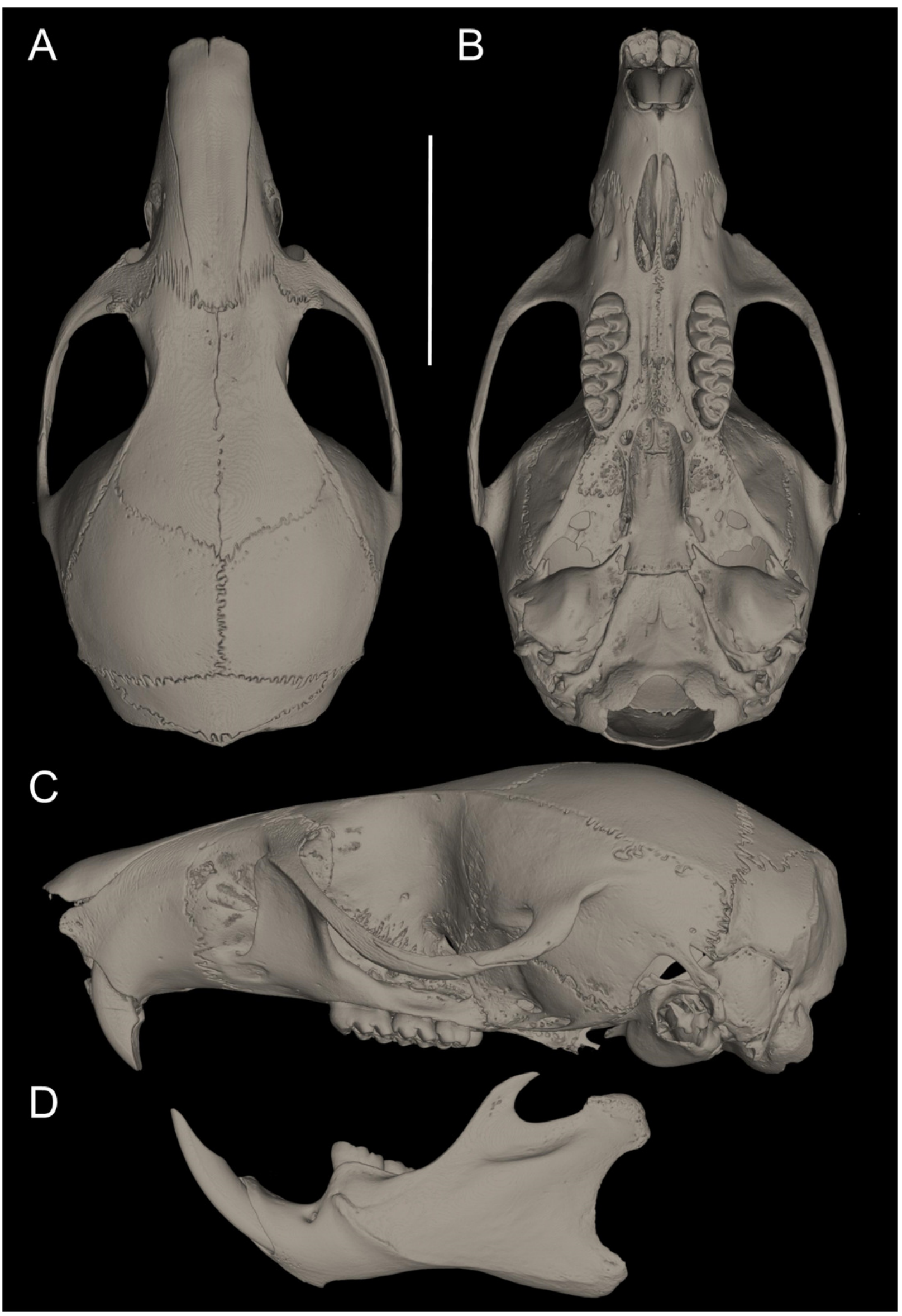




\section{Figure 14}

Four selected traits discussed in the main text illustrating molar variability in extinct ( $\dagger$ ) and extant oryzomyines.

Four selected traits discussed in the main text illustrating molar variability in extinct $(\dagger)$ and extant oryzomyines. Hypsodonty (A, ZFMK 2016-0981-sk, †Megaoryzomys curioi; B, MEPN 12605, Pattonimus musseri sp. nov.; C, CNP-E 882-2, Holochilus chacarius); lamination (D, BMNH 13.10.24.58, Mindomys hammondi; E, MEPN 11719, Transandinomys bolivaris; F, MEPN 12605, P. musseri sp. nov.); simplification (G, MECN 3407, Tanyuromys thomasleei; H, MEPN 12605, P. musseri sp. nov.; I, CNP 3964 Holochilus chacarius); m3 compression (J, MECN 3797, Nephelomys auriventer; K, MECN 6021, Sigmodontomys alfari; L, MEPN 12605, P. musseri sp. nov.). Abbreviations: $\mathrm{al}=$ anteroloph, $\mathrm{ml}=$ mesoloph. The arrow indicates the depth of the hypoflexus of the third molar, which denotes the hypsodonty. 


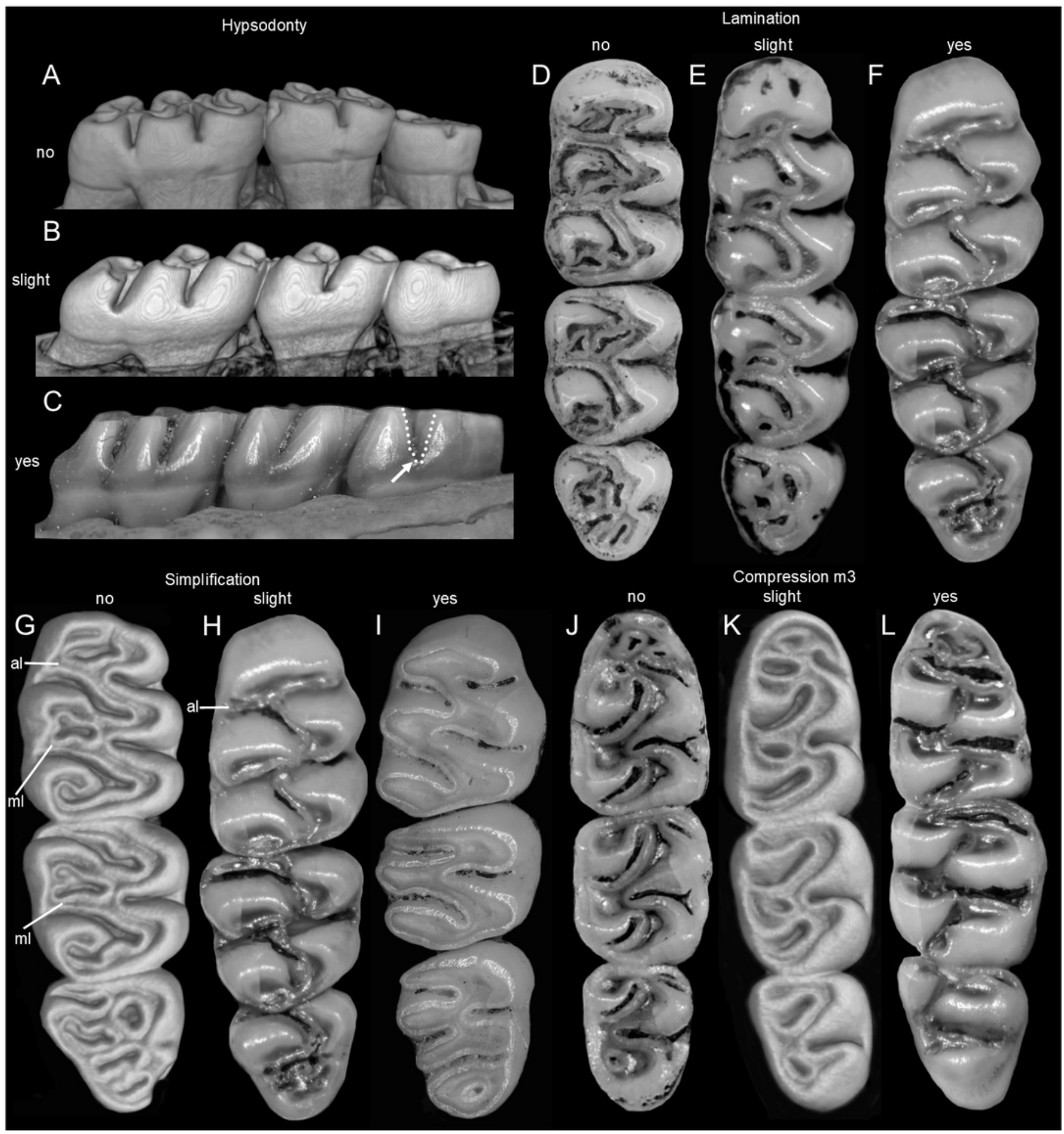

